\author{
UNIVERSIDADE DE SÃO PAULO \\ INSTITUTO DE PSICOLOGIA
}

\author{
CLAUDIA ARANHA GIL
}

\title{
RECORDAÇÃO E TRANSICIONALIDADE: A OFICINA DE CARTAS, FOTOGRAFIAS E LEMBRANÇAS COMO INTERVENÇÃO PSICOTERAPÊUTICA GRUPAL COM IDOSOS
}

SÃO PAULO

2010 


\section{CLAUDIA ARANHA GIL}

\section{RECORDAÇÃO E TRANSICIONALIDADE:}

\section{A OFICINA DE CARTAS, FOTOGRAFIAS E LEMBRANÇAS COMO INTERVENÇÃO PSICOTERAPÊUTICA GRUPAL COM IDOSOS}

Tese apresentada ao Instituto de Psicologia da Universidade de São Paulo, como parte dos requisitos para obtenção do título de Doutor em Psicologia.

Área de concentração: Psicologia Clínica

Orientadora: Profa. Dra. Leila Salomão de La Plata Cury Tardivo

\section{SÃO PAULO}




\section{CLAUDIA ARANHA GIL}

\section{RECORDAÇÃO E TRANSICIONALIDADE: A OFICINA DE CARTAS, FOTOGRAFIAS E LEMBRANÇAS COMO INTERVENÇÃO PSICOTERAPÊUTICA GRUPAL COM IDOSOS}

Tese apresentada ao Instituto de Psicologia da Universidade de São Paulo como parte dos requisitos para obtenção do título de Doutor em Psicologia.

Tese Defendida e aprovada em:

\section{BANCA EXAMINADORA:}

Prof. Dr Instituição:

Julgamento: Assinatura:

Prof. Dr Instituição:

Julgamento: Assinatura:

Prof. Dr. Instituição:

Julgamento: Assinatura:

Prof. Dr. Instituição:

Julgamento: Assinatura:

Prof. Dr. Instituição:

Julgamento: Assinatura: 
Dedico este trabalho à Angélica, Clara, Isa, Lucia, Tereza e a Bento, in memoriam.

A eles a minha gratidão. 


\section{AGRADECIMENTOS}

Agradeço, em especial, à minha orientadora, Prof ${ }^{a}$. Dra. Leila Salomão de La Plata Cury Tardivo que ofereceu todo o apoio e o incentivo necessários para que eu pudesse realizar esse trabalho. A minha profunda gratidão pela amizade, generosidade e confiança.

À Prof ${ }^{a}$. Dra. Tania Aiello-Vaisberg, pelas contribuições que me tem dado no percurso profissional e pelas valiosas sugestões apresentadas no exame de qualificação.

À Prof ${ }^{a}$. Dra. Kayoko Yamamoto, pela disponibilidade e pelas contribuições no exame de qualificação.

A todos os membros da banca examinadora, pela leitura, avaliação e discussão do estudo.

À Secretaria de Ação e Desenvolvimento Humano do minicípio onde ocorreu a pesquisa, pelo apoio ao trabalho realizado com o Grupo da Terceira Idade.

À equipe do APOIAR e da Ser e Fazer, do Laboratório de Saúde Mental e Psicologia Clínica Social do Instituto de Psicologia da USP, pela amizade, pelo incentivo, carinho e apoio. Tem sido muito bom partilhar tantos projetos com vocês.

Aos funcionários do Instituto de Psicologia da Universidade de São Paulo, em especial a Cláudia Lima da Rocha e a Cícera Eloi Andrade, pelo auxílio prestado sempre com gentileza.

Ao Ivan Rabelo, pela disponibilidade em realizar o tratamento estatístico.

À Maria Marta Nascimento, pelo apoio na revisão da formatação realizada.

À Elizete Zanotti, pela cuidadosa revisão que realizou com tanta disponibilidade e amizade.

À amiga Anelisa Macedo, que elaborou a tradução para o inglês.

À Marta Fonseca Rosa e à Dora de La Plata Cury, pela amizade, pelo carinho e incentivo constantes.

À Gina Kafiff Levinzon, pela acolhida e pelo cuidado com que tem me acompanhado.

A todos os meus amigos queridos com os quais tenho partilhado a vida. Obrigado por vocês estarem sempre ao meu lado. 
Aos meus sogros, Jaqueline e José António Caruso, que têm a cada dia me mostrado que tudo vale a pena.

À minha irmã Stella e às queridas sobrinhas Rafaela e Bruna, pelo carinho e apoio.

Aos meus pais João Francisco e Darcy, por serem pessoas maravilhosas que me apoiam e me incentivam em todos os momentos da minha vida.

Aos meus filhos Pedro e Gustavo, por todo o amor e compreensão.

Ao Ricardo, meu marido, por estar sempre ao meu lado com amor, dedicação e confiança. 


\section{Reinauguração}

Nossa idade - velho ou moço- pouco importa

Importa é nos sentirmos vivos e alvoroçados

Mais uma vez, e revestidos de beleza, a exata

Beleza que vem dos gestos espontâneos e do

Profundo instinto de subsistir enquanto coisas

Em redor se derretem e somem como nuvens

Errantes no universo estável.

Prosseguimos. Reinauguramos. Abrimos olhos

Gulosos a um sol diferente que nos acorda

Para os descubrimentos.

Esta é a magia do tempo

Esta é a colheita particular que se exprime no

Cálido abraço e no beijo comungante, no

Acreditar na vida e na doação de vivê-la em

Perpétua criação

E já não somos apenas finitos e sós.

(Carlos Drumond de Andrade, 1964/2002) 


\section{RESUMO}

\section{Gil, C.A. Recordação e Transicionalidade: A Oficina de Cartas, Fotografias e}

Lembranças como intervenção psicoterapêutica grupal com idosos. São Paulo. 2010. 181 f. Tese (Doutorado) - Instituto de Psicologia da Universidade de São Paulo, São Paulo, 2010.

O estudo tem o objetivo de apresentar a Oficina de Cartas, Fotografias e Lembranças como proposta de método psicoterapêutico dirigido a idosos, em um enquadre grupal, e verificar seu alcance e seus benefícios para esse grupo. A pesquisa foi desenvolvida com o método clínico, baseado na teoria psicanalítica e, em especial, na leitura dos conceitos winnicottianos. A proposta terapêutica, descrita no trabalho foi desenvolvida a partir dos temas de recordação e transicionalidade, cujos efeitos foram avaliados antes e depois da intervenção. Participaram do estudo seis idosos de ambos os sexos - um homem e cinco mulheres - com idade entre 65 e 79 anos, que frequentavam um Grupo de Terceira Idade. Para compreensão diagnóstica, foram realizadas duas entrevistas iniciais e aplicados os instrumentos WHOQOL-BREF (Inventário de Qualidade de Vida - Forma breve), o BDI - Inventário Beck de Depressão e o Teste de Apercepção Temática para Idosos - SAT. O estudo descreve o processo psicoterapêutico desenvolvido, realizado em grupo e de forma breve, durante 16 sessões, o movimento entre os campos que se evidenciaram e as mudanças que ocorreram na vida dos participantes. A partir da análise do processo psicoterapêutico, a proposta da Oficina desenvolvida com esse grupo se mostrou eficaz. Houve significativa melhora dos sintomas depressivos e, de modo geral, da qualidade de vida dos participantes que concluíram a participação no grupo. Ao final do estudo, observou-se que o enquadre utilizado na proposta terapêutica favoreceu maior integração e possibilidade de recordação saudável, refletindo vivências que apontaram para o crescimento emocional dos participantes do grupo.

Palavras-Chave: Envelhecimento. Oficina Criativa. Intervenção Psicoterapêutica. Psicoterapia do Idoso. Qualidade de Vida. Psicanálise. 


\begin{abstract}
Gil, C. A. Remembrance and Transitionality: The Workshop of Letters, Photographs and Memories as psychotherapeutic intervention of group with elderly. São Paulo: 2010 181p. Doctorate thesis - Institute of Psychology of University of São Paulo. 2010.
\end{abstract}

The aim of the present study is to show the Workshop of Letters, Photographs and Memories as a proposal of psychotherapeutic method focused on elderly at a group framework and verify its scope and benefits regarding this group. The research was carried out with the clinical method based on the psychoanalytical theory and specially the reading of Winnicott concepts. This therapeutic proposal described in the work was developed from topics of remembrance and transitionality, having its effects evaluated before and after the intervention. The group consisted of six elderly of both sexes, at ages ranging from 65 to 79 years old, being one man and five women, who attended a Group for The Elderly. Aiming the diagnostic comprehension, two initial interviews were performed and the instruments WHOQOL-BREF (Inventory of Quality of Life - brief mode), the BDI- Beck Inventory of Depression and the Thematic Apperception Test for Elderly- SAT were used. The study describes the psychotherapeutic process, conducted in group, briefly in 16 sessions, as well as the movement among the fields that became evident and the changes that occurred in the participants' lives. From the analysis of the psychotherapeutic process, the Workshop proposal carried out with this group proved to be efficient. There was a significant improvement of the depressive symptoms and, overall, of the quality of life of those who concluded their participation in the group. At the end of the study, it was possible to observe that the framework used in the therapeutic proposal contributed to a greater integration and a chance of healthy remembrance reflecting experiences that point to the emotional growth of the participants of the group.

Key-Words: Aging. Creative Workshop. Psychotherapeutic Intervention. Psychotherapy of the elderly. Quality of Life. Psychoanalysis. 


\section{RÉSUMÉ}

Gil, C.A. Souvenir et Transitionnalité: L'atelier de Lettres, Photographies et Souvenirs comme intervention psychothérapeutique en groupe avec des personnes agées. São Paulo: 2010, 181 p. Thèse de Doctorat - Institut de Psychologie de 1' Université de São Paulo. 2010.

Cette étude a comme but de présenter L'atelier de Lettres, Photographies et Souvenirs en tant que proposition de méthode psychothérapeutique adressé aux personnes agées dans le cadre d'un groupe et vérifier la portée et les bénéfices apportés à ce même groupe. La recherche a été développée avec la méthode clinique ayant comme base la théorie psychanalytique et notamment la lecture des concepts de Winnicot. Cette proposition thérapeutique décrite dans le travail a été développée à partir des thèmes de souvenir et transitionnalité, les effets de la même étant évalués avant et après cette intervention. Six personnes agées des deux sexes y ont participé, agées de 69 à 79 ans, un homme et six femmes, fréquentant un Groupe du Troisième Âge. Afin d'avoir une compréhension diagnostique, deux premiers entretiens ont été réalisés et les outils appliqués ont été les WHOQOL-BREF (Évaluation de la Qualité de Vie - forme brève), le BDI -Inventaire Beck de Dépression et le Test d'Aperception Thématique pour les Personnes Agées- SAT. L'étude décrit le processus thérapeutique développé, réalisé en groupe et de manière brève en seize séances, ainsi que le mouvement entre les deux champs qui se sont mis en évidence et des changements qui se sont opérés dans la vie des participants. À partir de l'analyse du processus thérapeutique, la proposition de l'Atelier développée avec ce groupe s'est avérée efficace. Il y a eu une amélioration significative des symptômes dépressifs et, d'une manière générale, de la qualité de vie des participants qui ont conclu leur participation dans le groupe. Au terme de l'étude, nous avons observé que le cadre utilisé pour la proposition thérapeutique a favorisé une plus grande intégration et une possibilité de souvenir sain, reflétant des expériences qui ont montré un développement émotionnel.

Mots-clés: Vieillissement. Atelier de Création. Intervention Psychothérapeutique. Psychothérapie pour les personnes âgées. Qualité de vie. Psychanalyse. 


\section{LISTA DE TABELAS}

Tabela 1 -WHOQOL - BREF - Inventário de Qualidade de Vida.............................. 148

Tabela 2 -Pontuação no BDI - Inventário Beck de Depressão..................................... 149

Tabela 3 - Graus dos Sintomas de Depressão....................................................... 149 


\section{SUMÁRIO}

RESUMO

ABSTRACT

RÉSUMÉ

LISTA DE TABELAS

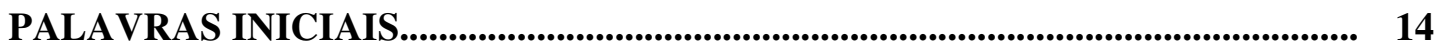

CAPÍTULO I - INTRODUÇÃO TEÓRICA............................................................. 18

1 - A velhice: Desafios e Criação de Novas Demandas no Campo da Saúde

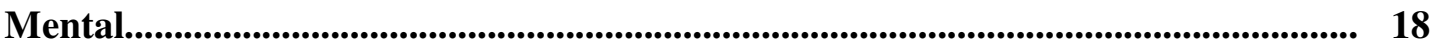

1.1 - Envelhecimento Populacional : Uma Questão Contemporânea................ 18

1.2 - O Múltiplos Sentidos da Velhice .................................................................. 20

2 - Intervenções Psicoterapêuticas Dirigidas ao Idoso : A Busca por Novos

Enquadres Clínicos................................................................................................. 23

2.1 - A Clínica Psicanalítica Dirigida ao Idoso....................................................... 23

2.2 - A Pesquisa com Enquadres Clínicos Diferenciados...................................... 26

3 - Memória, Recordação e Psicanálise.............................................................................. 30

3.1- A Memória e as Emoções........................................................................................ 30

3.2 - Recordação e Integração: Considerações a partir da Leitura da Obra de Winnicott..................................................................................................... 35

3.3- A Memória Emocional na Psicanálise Relacional........................................... 38

4 - Os Fenômenos Transicionais.................................................................................... 40

5 - A Oficina Psicoterapêutica de Cartas, Fotografias e Lembranças...................... 45

CAPÍTULO II - Justificativas e Objetivos................................................................... 54

CAPÍTULO III - O Percurso Metodológico.............................................................................. 56

1 - Considerações acerca do Método Clínico................................................................ 56

2- Participantes e Procedimentos............................................................................................. 61

3 - Enquadre e Aspectos Éticos............................................................................................. 69 
CAPÍtulo IV - Conhecendo os Participantes e o Processo........................................ 70

1- Apresentação dos Participantes..................................................................................................... 70

1.1-Angélica................................................................................................................. 70

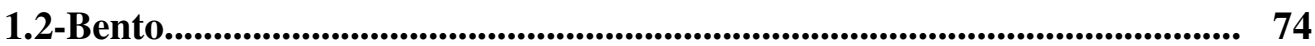

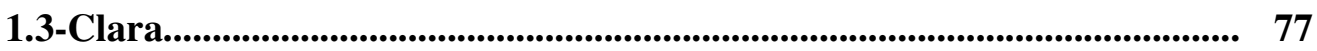

1.4-Tereza.......................................................................................................................... 81

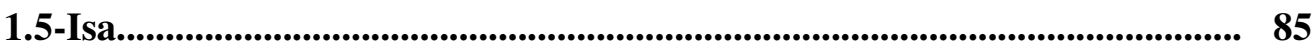

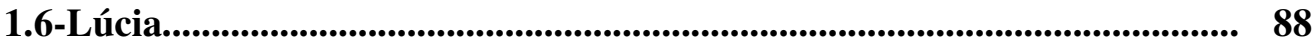

2- Resumos das Sessões da Oficina Psicoterapêutica de Cartas,

Fotografias e Lembranças.............................................................................................. 91

CAPÍTULO V - Compreendendo o Processo.................................................................... 127

1 - O Processo da Oficina Psicoterapêutica: Identificação e Transição entre

Campos Psicológicos................................................................................................................. 127

2- A Compreensão das Vivências Emocionais na Proposta

Terapêutica: Recordação e Transicionalidade.................................................... 140

3 - A Voz dos Participantes............................................................................................... 148

3.1 - Resultados das Escalas.............................................................................. 148

3.2 - Entrevistas Finais.......................................................................................... 150

CAPÍTULO VI - Síntese e Considerações Finais........................................................ 155

Referências....................................................................................................................................................... 158

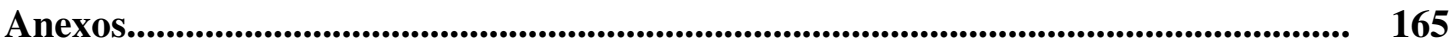




\section{PALAVRAS INICIAIS}

O presente estudo compõe uma trajetória de dez anos de trabalho voltada à prática clínica e à pesquisa com pacientes idosos. Esse percurso iniciou-se no Ambulatório Geral Didático do Hospital das Clínicas da FMUSP, onde, na condição de estagiária do curso de especialização em Psicologia Hospitalar, produzi um estudo sobre o psicodiagnóstico de idosos com depressão.

O interesse cada vez mais direcionado para as questões que envolvem o envelhecimento no campo da psicologia clínica, levou-me para o curso de Pós-Graduação no Instituto de Psicologia da Universidade de São Paulo. No Mestrado, pude acompanhar a criação do APOIAR, projeto abrigado no Laboratório de Saúde Mental e Psicologia Clínica Social e coordenado pela Professora Leila Salomão de La Plata Cury Tardivo, orientadora deste projeto. Desde então venho realizando atendimentos e desenvolvendo estudos e pesquisas, tanto no APOIAR quanto na Ser e Fazer - Oficinas Psicoterapêuticas de Criação, serviço que pertence ao mesmo Laboratório e é coordenado pela Professora Tania AielloVaisberg.

Esse caminho me aproximou a autores do campo psicanalítico, entre eles especialmente Winnicott, cuja teoria tem me inspirado nas pesquisas desenvolvidas com enquadres clínicos diferenciados e originado diversos trabalhos e publicações ao longo dos últimos anos. A pesquisa que deu origem a dissertação de Mestrado (GIL, 2005) refletiu esse percurso. O estudo, que tinha por meta compreender o idoso que buscava a clínica psicológica com sintomas de depressão, iniciou-se com uma concepção que privilegiava a vertente psicodiagnóstica. No entanto, o decorrer dos atendimentos apontou para uma nova perspectiva de intervenção, na qual os instrumentos projetivos utilizados como auxiliares no psicodiagnóstico, funcionavam fundalmentalmente como facilitadores e mediadores no contato terapêutico. Com um modelo inspirado nas consultas terapêuticas propostas por Winnicott, realizamos com os pacientes encontros terapêuticos que revelaram ser, ao longo do processo, potencialmente mutativos.

Ao realizar o atendimento de idosos que participaram da pesquisa, observei que, em algumas oportunidades, determinadas pacientes traziam aos nossos encontros fotografias ou objetos. A esse respeito, recordo-me de uma senhora que gostava de trazer fotografias de sua 
família e de um senhor que, vítima de um AVC, ditava, durante as sessões, cartas endereçadas à filha que não via há muitos anos. Lembro-me também de um senhor de 70 anos que trouxe um mapa astrológico feito quando ele tinha 20 anos de idade. Percebi que esse material, por vezes, parecia facilitar o contato com os pacientes, à medida que suscitava lembranças e associações que contribuíram para o trabalho psicoterapêutico.

Motivada por essas vivências, iniciei no ano de 2003 a Oficina Psicoterapêutica de Cartas, Fotografias e Lembranças, na Ser e Fazer - Oficinas Psicoterapêuticas de Criação, com a proposta de atender pacientes de idades diversas. Ao longo dos anos, fui observando que, embora houvesse alguns pacientes mais jovens, a maioria dos participantes que aderia à proposta terapêutica e permanecia no grupo era composta de idosos. Buscando ampliar o trabalho desenvolvido na Oficina, passei a utilizar esse enquadre nos atendimentos a pacientes psiquiátricos realizados nas instituições com as quais o Laboratório de Saúde Mental e Psicologia Clínica Social mantém parcerias. Essas experiências foram bastante frutíferas e apontaram para a potencialidade terapêutica de tal forma de enquadre clínico diferenciado.

A pesquisa que deu origem a esta Tese de Doutorado buscou reunir os dois temas que têm sido fundamentais na minha trajetória de Psicóloga clínica e pesquisadora: A Oficina de Cartas, Fotografias e Lembranças e o envelhecimento. Nesse sentido, o presente trabalho tem o objetivo principal de apresentar a Oficina como proposta de metódo psicoterapêutico dirigido a idosos em um enquadre breve, bem como compreender as vivências emocionais presentes na proposta, enfocando de modo especial àquelas relacionadas à recordação e à transicionalidade.

Esse trabalho está dividido em seis capítulos. No capítulo I são apresentados os principais fundamentos teóricos que nortearam a realização do estudo. A primeira parte foi reservada para a visão geral sobre a velhice, destacando que o crescente envelhecimento da populacão e o consequente aumento da expectativa de vida tem gerado novas demandas, e também desafios, no campo da saúde mental. A segunda parte aborda as intervenções psicoterapêuticas dirigidas ao idoso e as pesquisas que têm sido realizadas com enquadres clínicos diferenciados que possam criar condições de melhor oferta de cuidado a essas pessoas, no campo emocional.

A terceira parte da introdução teórica enfoca as relações entre memória, recordação e Psicanálise. Ela traz as principais contribuições de Freud e outros autores do âmbito psicanalítico, sobre o tema, como André Green (2007, 2008) e Salvarezza (1993, 2005). A 
partir da leitura da obra de Winnicott, autor que fornece as principais bases teóricas de nosso estudo, procuramos também estabelecer relações entre recordação e integração. Com o objetivo de ampliar a visão sobre essas questões, incorporamos ao final dessa parte o conceito de memória emocional presente na Psicanálise Relacional. A quarta parte, assim como a anterior, destaca-se por abordar os principais conceitos teóricos utilizados no estudo, quais sejam: os conceitos de transicionalidade e espaço potencial, bem como algumas expansões na clínica contemporânea. A quinta parte apresenta a Oficina psicoterapêutica de Cartas, Fotografias e Lembranças, em seus aspectos teóricos e também os específicos às pesquisas que temos desenvolvido com essa proposta.

O capítulo II apresenta os principais objetivos da pesquisa, bem como as justificativas para sua realização. O capítulo III concentra-se no percurso metodológico, passando inicialmente por algumas considerações sobre o método clínico empregado no estudo e, na sequência, discorrendo sobre as etapas do processo e sobre os instrumentos empregados. $\mathrm{O}$ capítulo IV intitulado "Conhecendo os participantes e o processo" visa, em um primeiro momento, apresentar os participantes do estudo. Para atingir esse objetivo foram realizadas, a partir das entrevistas iniciais, sínteses de compreensão clínica referente a cada participante. Em seguida, enfocamos o processo relativo ao método empregado no estudo e apresentamos o resumo das 16 sessões da Oficina Psicoterapêutica de Cartas, Fotografias e Lembranças, ilustrados por fotografias referentes a cada sessão.

$\mathrm{O}$ capítulo $\mathrm{V}$ apresenta as reflexões e considerações provenientes do processo vivênciado pelos integrantes do grupo, durante as sessões da Oficina. A partir do diálogo com os autores que fundamentaram a introdução teórica buscamos discutir as nossas observações, em especial, sob a ótica dos aportes teóricos inspirados no pensamento de Winnicottt e no conceito de campo psicológico desenvolvido por Bleger (1963/1984). A discussão, portanto, parte da identificação dos campos psicológicos estabelecidos nos encontros da Oficina e na transição entre eles. Posteriormente, são apresentadas considerações sobre a compreensão das vivências emocionais da proposta terapêutica na perspectiva da recordação e da transicionalidade. O capítulo é encerrado com a visão dos próprios participantes, levando em conta os resultados das reaplicações dos instrumentos objetivos empregados e dos relatos dos participantes surgidos nas entrevistas realizadas ao final do processo. 
O capítulo VI traz, por fim, a síntese dos principais aspectos relativos à compreensão do processo vivenciado na Oficina Psicoterapêutica de Cartas, Fotografias e Lembranças, seguida de considerações sobre os resultados da pesquisa. 


\section{CAPÍTULO I - INTRODUÇAO TEÓRICA}

Apresentamos neste capítulo os principais fundamentos teóricos que nos nortearam na realização deste estudo. Com relação aos temas abordados, iniciamos com uma visão geral sobre a velhice, destacando que o envelhecimento populacional tem gerado novas demandas no campo da saúde mental. Em seguida, focalizamos a clínica psicanalítica dirigida ao idoso, e a necessidade da busca por novos enquadres clínicos que possam melhor atender a essas pessoas.

Passamos então a abordar os principais conceitos teóricos utilizados no estudo. Assim, a terceira parte compreende as relações entre a memória, a recordação e a psicanálise, partindo dos conceitos de Freud e principalmente de Winnicott, autor que fornece os aportes teóricos fundamentais ao nosso trabalho e que, por isso, recebe destaque na quarta parte, quando falamos sobre os conceitos de transicionalidade e espaço potencial, bem como suas expansões na clínica contemporânea. Por fim, apresentamos os aspectos teóricos e as pesquisas desenvolvidas com o enquadre da Oficina Psicoterapêutica de Cartas, Fotografias e Lembranças.

\section{1 - A Velhice: Desafios e Criação de Novas Demandas no Campo da Saúde Mental}

\section{1 - Envelhecimento Populacional: Uma Questão Contemporânea}

O crescente envelhecimento populacional e o consequente aumento da expectativa de vida se consolidaram como uma tendência mundial. Segundo o Programa de Envelhecimento da Organização das Nações Unidas (ONU), esse crescimento vem sendo observado de modo mais acentuado em países em desenvolvimento; proporcionalmente, porém, a representatividade do número de idosos em países desenvolvidos é maior. Atualmente, um em cada cinco europeus tem 60 anos ou mais; no entanto, somente um entre 20 africanos pertence a essa faixa etária. De acordo com dados de 2005, as pessoas com 60 anos ou mais representavam $11 \%$ da população mundial. As projeções demográficas apontam que em 2050 
esse valor será superior a $22 \%$. A população que mais cresce no mundo, hoje, é composta de mulheres com mais de 80 anos e, em especial, o grupo composto por centenárias, que em 2005 representava 265.0000 pessoas, e que deve aumentar para 3.7 milhões em 2050 (ONU, 2010).

O Brasil caracteriza-se por um processo de acelerada transição demográfica, marcada por grande aumento da população idosa e tendência de decréscimo da população jovem. Segundo dados do Instituto Brasileiro de Geografia e Estatística (IBGE), em 2008, o número de pessoas com mais de 60 anos em nosso país totalizava cerca de 21 milhões, dos quais cerca de 5,5 milhões com mais de 75 anos, em sua maioria constituída por mulheres. Entre 1998 e 2008, a proporção de idosos aumentou de $8,8 \%$ para $11,1 \%$. Ao realizar a análise das condições de vida da população brasileira, o IBGE (2008) avaliou também a intensidade do processo de longevidade, pois, na faixa etária de 80 anos ou mais, o crescimento - quase de $70 \%$ em dez anos - superou o número de idosos pertencentes às demais faixas etárias.

Veras (2009), importante pesquisador da área da epidemiologia do envelhecimento, ao analisar o impacto dessa realidade em nosso país, aponta o quanto os modelos de assistência à saúde voltados para o idoso se mostram ineficazes e de alto custo em face da grande demanda existente. Ele ressalta que as políticas de saúde para os idosos devem enfatizar formas de prevenção com o objetivo de manter a capacidade funcional desses indivíduos, ou seja, manter as habilidades físicas e mentais necessárias para uma vida autonôma.

De modo claro, observamos que a ênfase da análise das políticas públicas voltadas ao idoso está no adoecimento físico e na necessidade de uma reestruturação do sistema de saúde aplicado à área do envelhecimento. No entanto, como também ressalta Veras (2009), o cuidado deve ser dirigido considerando a atenção integral à saúde; em outras palavras, priorizando também as ações relacionadas à saúde mental que possam refletir a abertura de campos que favoreçam a elaboração de novos significados para a velhice.

Devemos considerar também, no que diz respeito à saúde mental do idoso, que as consequências das mudanças demográficas, que se apresentam hoje como realidade tanto em nosso país como no mundo, geram apreensão quanto ao seu impacto. $\mathrm{O}$ aumento dos índices de depressão e demências em idosos se destaca tanto pela elevada prevalência como pelas consequências que acarretam nas vidas dessas pessoas. (VERAS, 2009).

Como exemplo, podemos destacar o Projeto SABE (Saúde, Bem-estar e Envelhecimento), coordenado pela Organização Pan-Americana de Saúde com o objetivo de coletar informações sobre as condições de vida dos idosos residentes em áreas urbanas de sete países da América Latina e Caribe, entre eles o município de São Paulo. Os resultados 
relativos à saúde neste município, dentre outros aspectos, indicaram a presença de $6,9 \%$ de idosos com algum nível de deterioração cognitiva e 18,1\% com depressão (LEBRÃO; LAURENTI, 2005).

Cabe ressaltar que, nesse panorama, os sistemas nacionais de saúde enfrentam inúmeros problemas para tornar acessível o tratamento à população idosa. Sabemos que os equipamentos de saúde pública são muitas vezes insuficientes e carecem de um número de profissionais aptos a oferecer o tratamento necessário, o que torna premente a criação de novos modelos que venham a atender tais demandas.

\section{2 - Os Múltiplos Sentidos da Velhice}

Analisadas até aqui, inicialmente, do ponto de vista demográfico, essas novas demandas, e também os desafios gerados pelo envelhecimento, apontam também para a necessidade de compreender melhor qual a identidade do indivíduo que, ao completar 60 anos, nos dias de hoje é considerado parte da terceira idade. Sobre quem estamos falando afinal? Sob o risco de uma visão reducionista, que tende a enxergar o idoso de forma estática e muitas vezes compartimentalizada, devemos considerar que a imagem e o comportamento das pessoas nessa etapa da vida têm se modificado, principalmente nos últimos anos.

Como mostra Ferrigno (2006), se, por um lado, nos referimos à identidade do idoso como aquela relacionada ao esvaziamento dos papéis e a perdas das mais diversas naturezas, por outro, estamos falando também daquele que enfrenta as consequências naturais do envelhecimento de forma participativa e integrada. Esse autor, ao problematizar a questão da identidade do jovem e do velho na contemporaneidade, relembra de maneira bastante interessante que, afinal de contas, quem completa sessenta nos dias de hoje foi adolescente na década de sessenta e assistiu a grandes mudanças no campo da ciência, tecnologia e cultura. Época de autênticas revoluções de comportamento; muitos que eram jovens naquela época viveram experiências de contestação, por exemplo, nos movimentos feministas e estudantis, no cenário político da época. Isso nos faz pensar que o idoso de hoje poderá vir a ter maior possibilidade de, ao questionar estereótipos e à mera reprodução de comportamento de seus pais e avós, construir uma velhice mais saudável, não só em relação à saúde física, mas também mental. 
Ao abordar a questão da identidade do idoso, Minayo (2006), em uma perspectiva antropológica, refere que a velhice não constitui uma categoria homogênea de análise e que é necessário considerar as diferenças. Portanto, se não levarmos em conta essa heterogeneidade, corremos o risco de evidenciar os estereótipos e, nesse sentido, deixar de ressaltar o que é de fundamental importância: a singularidade e a subjetividade do idoso. Assim, nas palavras da autora: "De modo geral, é absolutamente diferente envelhecer no campo ou na cidade; numa família rica ou numa família pobre; ser homem ou mulher; ter tido um emprego e se aposentar, ou ter vivido apenas em atividades do lar ou informais e viver de forma independente." (MINAYO, 2006, p. 48).

Buscando uma aproximação da velhice da perspectiva da saúde mental, apoiamo-nos nos pressupostos de Bleger (1963/1984), que deixa claro em sua obra a ideia de que, quem concebe o objeto de estudo, é o ser humano, e considera como objeto de todas as ciências humanas o fenômeno humano. Este, embora vivenciado nas áreas do corpo, da mente e em seus aspectos relacionados com o meio externo, será sempre visto de modo unitário e individual. Em outras palavras, contitui-se como demanda, e também desafio, na atualidade, compreender o idoso não como uma categoria a ser estudada em uma relação marcada pelo paradigma sujeito-objeto, mas sim levando em conta a aproximação do ser humano em uma dimensão existencial, considerando seus aspectos singulares e sua subjetividade, em uma clara relação sujeito-sujeito.

A partir da revisão bibliográfica realizada por ocasião da elaboração da Dissertação de Mestrado (GIL, 2005), pudemos levantar alguns aspectos importantes. Sabemos que o envelhecer é um processo complexo, que abrange aspectos biológicos, sociais e psicológicos. É também uma experiência singular que ocorre à medida que cada indivíduo percorre o ciclo natural da vida. Podemos considerar, portanto, o campo do envelhecimento como um campo de investigação interdisciplinar, permeado pela necessidade de compreender a velhice em seus múltiplos aspectos.

Neri (2006), autora de destaque na área da Psicologia do envelhecimento em nosso meio, traça um histórico no qual ressalta que, somente a partir da década de 1960, as ideias que relacionavam o envelhecimento como época marcada por perdas de diversas naturezas começaram a se modificar. A necessidade de um estudo mais sistemático dos aspectos psicológicos da velhice, que pudesse trazer novas perspectivas sobre o assunto, foi desencadeada por diversos fatores. Entre eles, devemos considerar que, além do próprio advento do envelhecimento populacional, muitos dos cientistas que, naquela época desenvolviam teorias e pesquisas sobre a psicologia infantil e da adolescência, aproximavam- 
se da velhice e foram constatando que, por vezes, muitas das crenças consideradas verdadeiras não correspondiam à realidade do envelhecimento que percebiam em si mesmos. Ao mesmo tempo, nos Estados Unidos, os movimentos sociais que lutavam pelos direitos das minorias, entre eles os idosos, passaram a se interessar cada vez mais pelos fatores que determinavam um envelhecimento considerado saudável.

O conceito de processo de individução, desenvolvido por Jung (1971), bem como a análise das diferentes fases do desenvolvimento da personalidade que se sucedem ao longo da vida, segundo Erikson (1972), precederam as ideias de Paul P. Baltes (2000, apud NERI, 2006) sobre o conceito de lifespan ou o desenvolvimento que ocorre por toda a vida. De acordo com esse paradigma, considerado um marco na psicologia do envelhecimento, ocorrem variações durante toda a vida, embora na infância haja maior preponderância de ganhos e na velhice, por sua vez, de perdas. O desenvolvimento está relacionado, assim, à capacidade da criação de equilíbrio entre ganhos e perdas, em um movimento em direção à adaptação que deve ocorrer em qualquer fase da vida.

Essa visão de um potencial de transformação associado ao processo de envelhecimento embasa um tema de destaque nos dias de hoje: a velhice bem sucedida. Inicialmente considerado de uma perspectiva com pouca fundamentação na realidade, ao valorizar a ausência de doenças e o alcançe máximo de atividades e desenvolvimento nesta etapa da vida; nos últimos anos esse modelo tem sofrido modificações importantes em seu enfoque. Segundo Neri (2006), “o modelo psicológico de envelhecimento bem sucedido, baseado em processos de otimização seletiva com compensação, significa simplesmente fazer e ser o melhor possível com os recursos de que se dispõe." (p. 32).

Teixeira e Neri (2008) ampliaram essa ideia ao apontar a subjetividade do conceito de envelhecimento bem sucedido. Para as autoras, o critério da longevidade não deve ser utilizado de forma exclusiva, pois devem ser levados em conta os fatores individuais, sociais, psicológicos e biológicos. Desse modo, na avaliação do "bem estar subjetivo" do idoso, deve ser considerada não só a análise objetiva dos dados, mas sua integração com as percepções pessoais do indivíduo. O envelhecimento bem sucedido pode ser compreendido, sob esse prisma, como um princípio organizacional que age no sentido do estabelecimento de objetivos que levem em conta a realidade externa, principalmente no que diz respeito às possibilidades de adaptações a mudanças em tal fase da vida.

Muitas vezes, uma visão assistencialista e esteriotipada da velhice pode gerar, de modo paradoxal, um indivíduo que, nessa fase da vida, ao adquirir uma postura mais passiva e frágil, sente-se excluído e sem um verdadeiro lugar no mundo que o cerca (GIL, 2005). Ao 
rever o conceito de fragilidade muitas vezes relacionada ao idoso, Goldfarb (2006) acredita que este deve participar de todas as decisões que a ele se refere, "pois a escuta do desejo, a habilitação da palavra e a legitimação da vontade não são benefícios outorgados, mas direitos a serem exercidos." (p. 79).

Considerando desse modo, tanto as características atribuídas à velhice, quanto à visão necessária que deve privilegiar a singularidade do idoso, devemos levar em conta no campo da Saúde Mental a demanda pelo cuidado ao sofrimento psíquico. Como pudemos observar, vários órgãos internacionais e nacionais têm se ocupado das consequências do crescente envelhecimento populacional. Entre eles podemos citar o Programa de Envelhecimento e Saúde da Organização Mundial de Saúde. Kalache (2008), coordenador desse programa, ao apresentar os eixos que estruturam as mais recentes discussões nessa área, aponta, entre outras, para a necessidade do desenvolvimento de estratégias de prevenção, bem como para importância do desenvolvimento de novos mercados e produtos. Nesse sentido, a busca por enquadres clínicos diferenciados que possam atender melhor às necessidades dos indivíduos na velhice, propiciando o cuidado emocional necessário, tem sua importância validada.

\section{2- Intervenções Psicoterapêuticas Dirigidas ao Idoso: A Busca por Novos Enquadres Clínicos}

\section{2 - A Clínica Psicanalítica Dirigida ao Idoso}

A compreensão dos aspectos emocionais do indivíduo que envelheceu tem sido objeto de estudo de certos autores ao longo dos anos. De início com uma produção, principalmente na área da psicanálise, bastante escassa, o fenômeno do envelhecimento populacional tem gerado cada vez mais a necessidade de pesquisas também nesse campo.

Em uma perspectiva histórica, observamos que as primeiras questões relativas ao tema surgiram no início do século XX, introduzidas por Freud (1905/1990) que acreditava na impossibilidade de ser aplicado às pessoas mais velhas o método psicanalítico que criara. Um pouco mais tarde Karl Abraham (1927/1970), ao rever essa ideia, destacou que, no tratamento de pessoas idosas, deveria ser considerada a singularidade dos processos mentais de cada 
indivíduo e não somente o fator idade, antes de se decidir sobre a possibilidade ou não de ser aplicado o método psicanalítico. Ferenczi (1939/1993) abordou as psiconeuroses do envelhecimento embasado no conceito freudiano do narcisismo, e suas observações surgiram a partir do tratamento de pacientes que não conseguiam, no processo de envelhecimento, modificar a distribuição da libido, ou mesmo adaptá-la frente a essa nova condição, ocorrendo um processo de regressão narcísica.

Nas últimas décadas, seja devido ao advento do envelhecimento populacional, ou mesmo porque muitos dos teóricos que pesquisam e atuam nessa área vivenciaram, eles próprios, a experiência da velhice, tornou-se incontestável a ideia da eficácia e indicação da psicoterapia na velhice frente à demanda por cuidados no campo da saúde mental. As intervenções psicoterapêuticas dirigidas ao idoso e, de modo mais especifico, as intervenções de base psicanalítica, têm se tornado, cada vez mais, objeto de estudo de vários autores contemporâneos.

Salvarezza (2005) ressalta que a indicação da psicoterapia para o idoso faz parte de um tripé em que estão incluídas a psicofarmacologia, quando necessária, e a psicoterapia de apoio com os familiares. A eficácia terapêutica, então, será relativa aos recursos disponíveis utilizados. A partir de uma extensa pesquisa bibliográfica sobre o tema, o autor coloca que as dificuldades atribuídas à realização da psicoterapia, especialmente psicanalítica na velhice, estão geralmente relacionadas aos próprios psicanalistas.

A ênfase é dada na importância de uma boa formação do psicanalista, considerando sua formação técnica especializada e análise pessoal. Para o autor, ainda, a maior parte das dúvidas quanto à aplicabilidade da psicanálise da velhice diz respeito, muitas vezes, a aspectos da técnica. Desse modo, é comum a aceitação do método psicanalítico pelos próprios psicanalistas, desde que haja modificações (sobre a duração do tratamento, duração das sessões, profundidade das interpretações, etc). No entanto, o uso da técnica psicanalítica pode ser empregado em qualquer idade e as resistências dos psicanalistas são atribuídas aos preconceitos profundamente arraigados sobre a velhice e, principalmente, aos aspectos contratransferenciais (SALVAREZZA, 2005).

A visão que considera o tratamento psicanalítico um encontro de inconscientes, e que, portanto, independe tanto da idade do paciente quanto do psicanalista, embasa o pensamento de Messy (1999), autor francês que propõe uma abordagem psicanalítica da velhice. Para o autor, o que está em jogo são os desejos e, por isso, a idade não é um fator que interfere na psique. 
Para Chapot (2009) o trabalho psicoterapêutico com idosos, bem como sua inserção em uma rede social, permite-lhes enxergar a possibilidade de experimentar outras maneiras de envelhecer. É possivel, assim, dar novos significados a essa fase de vida, resgatando potencialidades, independentemente da idade cronológica. Em seu estudo, ele relata um caso clínico de uma senhora de 68 anos. É descrito um processo, em que a analista, levando em conta a singularidade da paciente, trabalha nas sessões com o foco no relato de sonhos que ela lhe traz quase que semanalmente. É a partir desses relatos, que são feitas associações com as várias fases de sua vida. Com o passar do tempo, foi observado que aquela senhora pôde, por meio desse processo, elaborar os conteúdos psíquicos, possibilitando assim alívio do sofrimento e maior integração de Self.

No Brasil, podemos citar os trabalhos de Gavião (1996, 2002) como contribuições importantes na área do envelhecimento comprendido sob a luz da psicanálise. A autora observou que a psicoterapia psicanalítica breve, ao favorecer aspectos como estabilidade emocional, maturidade, introspecção, bem como a manutenção do interesse pelos relacionamentos, mostrou-se adequada quando realizada com pessoas mais velhas, pois estas muitas vezes, ao lidar com relacionamentos mais restritos e com a proximidade da morte, obtêm um bom aproveitamento do processo terapêutico.

Em um estudo realizado em 2002 com 180 idosos, a mesma autora concluiu que a integração da experiência de ter que lidar com a própria finitude resulta, muitas vezes, em ampliação do desenvolvimento emocional rumo a uma vida mais rica e criativa. Ela também destacou que, nas organizações defensivas como as esteriotipias, os processos de depressão patológica não representam obrigatoriamente características inerentes do envelhecimento, mas podem ser resultado de fragilidades da personalidade e de fatores socioculturais. Nesta perspectiva, de modo semelhante às nossas conclusões em um estudo posterior (GIL, 2005), as vivências depressivas dos idosos podem significar um processo emocional mais saudável e não necessariamente patológico.

Ainda nesse mesmo contexto, observamos também a dificuldade do idoso não só em buscar por psicoterapia, mas também em aderir ao tratamento. Em muitos casos, podemos atribuir essa questão a dificuldades de adaptação a um enquadre terapêutico mais tradicional, que utilize, por exemplo, os dispositivos freudianos padrões, que nem sempre favorecem a aderência ao tratamento (GIL, 2005). Essas questões têm motivado a busca por novos enquadres clínicos que criem condições para a participação do idoso, oferecendo assim o cuidado necessário no campo emocional. 


\section{2 - A Pesquisa com Enquadres Clínicos Diferenciados}

Em palestra proferida na Sociedade Psicanalítica Britânica em 1962, Winnicott, ao referir-se aos objetivos do tratamento psicanalítico, amplia essa ideia e abre caminho para novas perspectivas, quando diz: "Gosto de fazer análise e sempre anseio por seu fim. A análise só pela análise para mim não tem sentido. Faço análise porque é do que o paciente necessita. Se o paciente não necessita de análise então faço alguma outra coisa." (WINNICOTT, 1962/ 1983, p. 152).

Ainda que nesse artigo Winnicott deixe claro que, no tratamento psicanalítico, procura manter-se em direção a uma análise nos moldes tradicionais, é possível vislumbrar uma prática psicanalítica que não necessariamente utilize o enquadre freudiano padrão no qual é necessário, por exemplo, o divã ou um grande número de sessões por semana.

Quando nos referimos à pesquisa com enquadres clínicos diferenciados, devemos inicialmente considerar que o termo enquadre foi introduzido no campo da Psicanálise por José Bleger, em 1963, com o objetivo de descrever formas relativas ao estudo das condutas pelas ciências humanas. Mais tarde, em 1968, ele faz referência ao termo no contexto psicanalítico destacando o papel do analista com relação às questões de espaço e tempo, em uma abordagem na qual conclui que o enquadre diz respeito muito mais ao aspecto estratégico do que técnico (AIELLO-VAISBERG, 2004).

Em uma perspectiva histórica, a psicanálise se constituiu como método de investigação que se utiliza, além da associação livre e interpretação, da observação do campo transferencial. Segundo as teorias propostas por Freud e Melanie Klein, portanto, era essencial que a aplicação desse método ocorresse em um setting específico, e o que não correpondesse a isso era considerado psicanálise aplicada ou estendida, mas não o real método psicanalítico. Segundo Safra (2009), essa situação irá se modificar principalmente com as contribuições de Winnicott, autor cuja observação do campo transferencial foi além do setting encontrado nos consultórios.

$\mathrm{Na}$ visão de Safra (2009), a elaboração do conceito de Espaço Potencial (WINNICOTT, 1967/1975), considerado nuclear em sua formulação teórica, é a grande responsável por essa expansão do setting psicanalítico. É a partir desse conceito que, para o indivíduo, é possível então, do ponto de vista do campo transferencial, estar presente no mundo e na cultura. Nesse sentido, a criação do conceito de espaço potencial, ao não estar restrito a um espaço determinado, permite um método de investigação em qualquer ambiente 
e, portanto, é o que fundamenta as nossas pesquisas atuais com enquadres clínicos diferenciados, do ponto de vista da teoria winnicottiana.

Considerar a psicanálise como método, e não somente como técnica, tem nos motivado a empreender um caminho em direção à pesquisa e à prática clínica, que embasam, como pontua Tardivo (2008, p. 3), “[...] a formação do psicólogo no campo da saúde mental em sua concepção mais ampla, ou seja, no que diz respeito ao estudo da compreensão e intervenção a pessoas em situação de sofrimento [...]”. Nesse percurso, temos desenvolvido, ao longo dos últimos anos, pesquisas com intervenções psicoterapêuticas que utilizam enquadres clínicos diferenciados, buscando a interlocução com vários autores da psicanálise, entre eles, especialmente, Winnicott.

Quando pensamos de modo mais específico em uma clínica que se propõe a atender pessoas na velhice, entrar em contato com o sofrimento psíquico causado, em muitos casos pela exclusão que se dá não só no âmbito social mas também no familiar, constitui-se em verdadeiro desafio. Além disso, lidar com perdas e limitações físicas, com o medo da proximidade da morte, e o temor, este mais contemporâneo que todos talvez, de ser acometido pelo mal de Alzheimer e tantos outros, são fatores que geram intensas angústias.

Frente a essa demanda, os enquadres tradicionais que se traduzem em psicoterapias individuais e de longa duração nem sempre são eficazes, mesmo porque, não raro, o idoso apresenta sérias resistências a procurar ajuda psicológica, por vezes em consequência do próprio preconceito ou também, em muitos casos, por dificuldades econômicas. (GIL, 2005).

Da pesquisa com enquadres clínicos diferenciados dirigidos ao idoso resultou o nosso estudo (GIL, 2005), cujo objetivo principal foi compreender o que busca a clínica psicológica com sintomas de depressão. Foram realizadas narrativas de dois atendimentos clínicos com sintomas de depressão, que ocorreram em 10 a 12 sessões individuais, com uma sessão semanal. Utilizamos naquele estudo os instrumentos projetivos: Questionário Desiderativo e Teste de Apercepção Temática para Idosos (SAT), empregados não só como auxiliares no psicodiagnóstico, mas como facilitadores e mediadores no contato terapêutico. Com um modelo inspirado nas Consultas Terapêuticas propostas por Winnicott (1965/1994), apresentamos os Encontros Terapêuticos como forma de intervenção psicoterápica dirigida ao idoso, os quais demonstraram ser, ao longo do processo, potencialmente mutativos. 
Temos realizado, nos últimos anos, pesquisas com enquadres clínicos que utilizam materialidades mediadoras, ${ }^{1}$ como elementos de intervenção psicanalítica dirigida ao idoso, inspirada na psicanálise winiccottiana. Mais recentemente, apresentamos o trabalho desenvolvido com um paciente de 60 anos, com diagnóstico de transtorno depressivo grave, várias tentativas de suicídio e sucessivas internações psiquiátricas. Nesse tipo de enquadre foram empregados, durante o atendimento psicoterápico, desenho e pintura, com o objetivo de favorecer a comunicação emocional, e também a técnica projetiva TAT, cujas pranchas foram utilizadas não só como elemento diagnóstico, mas também como mediador no contato terapêutico. Após o período de um ano, com atendimento semanal, foi observado que o paciente estava mais integrado, apresentando melhora significativa dos sintomas depressivos, e capaz de romper o ciclo das várias internações psiquiátricas em um curto espaço de tempo. Concluímos no estudo que a utilização da materialidade mediadora favoreceu a melhora do paciente, facilitando a expressão de aspectos emocionais e elaboração dos conteúdos psíquicos (BARROS; GIL; TARDIVO, 2010).

Manna e Aiello-Vaisberg (2006) relatam o atendimento grupal de idosos por meio da Oficina Psicoterapêutica de Tapeçaria e Outros Bordados, realizado no contexto da Ser e Fazer - Oficinas Psicoterapêuticas de criação. Trata-se de um enquadre clínico baseado na psicanálise Winicottiana e que trabalha com materialidades mediadoras (no caso, lã, talagarça e agulhas), facilitadoras da expressão emocional dos participantes. Segundo as autoras, tratase de uma clínica que busca a superação da dissociação de aspectos do "Self e que oferece cuidados favorecedores da continuidade do ser e do compartilhamento de experiências" (p. 114).

Em nosso meio, observamos que o número de estudos com enquadres clínicos breves, dirigidos ao idoso, tanto individual quanto em grupo, tem aumentado progressivamente. $\mathrm{O}$ atendimento por meio da psicoterapia breve operacionalizada foi tema da pesquisa desenvolvida por Altman et al (2008). O estudo foi realizado com o objetivo de verificar como a psicoterapia breve operacionalizada pode auxiliar as pessoas idosas a se adaptarem melhor a seu momento atual de vida. $\mathrm{O}$ artigo relata o atendimento de uma paciente e, a partir dos resultados alcançados, as autoras concluem que os enquadres terapêuticos breves

\footnotetext{
1 Trata-se de pesquisas desenvolvidas no Laboratório de Saúde Mental e Psicologia Clínica Social do Instituto de Psicologia da Universidade de São Paulo - Projetos APOIAR e SER E FAZER.
} 
mostram-se adequados para auxiliar na detecção, prevenção e resolução de conflitos e problemas ligados tanto a questões pessoais quanto àquelas relacionadas ao envelhecimento.

Schawarz (2009) propõe uma forma de intervenção por meio da psicoterapia grupal breve dirigida aos idosos. A partir do aporte teórico da Psicologia Analítica, a autora trabalhou com um grupo de sete idosos. Foi utilizado o Método de Rorschach como teste e reteste para avaliar a evolução de cada participante e a do próprio grupo. $\mathrm{O}$ foco delimitado foi autoestima e, durante as sessões, foram usados recursos expressivos (desenhos), material onírico e relaxamento. Como conclusões, foram apontados benefícios decorrentes do processo psicoterápico, tais como: maior controle da ansiedade; redução do nível de crítica, do nível de ansiedade e de medo associados às relações interpessoais; não reaparecimento de conteúdos relacionados à impulsividade e ao descontrole; controle emocional mais eficaz e afetividade mais viva, com mais abertura para o contato com o outro.

O AT (Acompanhamento Terapêutico) vem sendo cada vez mais utilizado como forma de intervenção destinada a idosos que apresentam quadros depressivos, demências, sequelas de AVC, e ainda processos de institucionalização ou desinternação, entre outros. Como pontua Goldfarb (2006), originalmente destinados ao acompanhamento de pacientes psicóticos, o AT favorece o idoso que não pode ou quer deslocar-se até o local de atendimento, ao proporcionar o atendimento psicológico fora dos dispositivos tradicionais de tratamentos (consultório, hospitais, etc.). Ao favorecer o cuidado psíquico necessário, o AT não substitui o trabalho do cuidador do idoso, mas o pontencializa ao estabelecer um vínculo de confiança e trabalhar com a elaboração dos conflitos gerados pela atual condição de vida. 


\section{3 - Memória, Recordação e Psicanálise}

\section{1- A Memória e as Emoções}

As questões relacionadas à memória e, portanto, também à temporalidade, têm sido temas de estudo em várias áreas do conhecimento. Cientistas, filósofos, escritores, historiadores, artistas e também psicanalistas ${ }^{2}$ têm, ao longo dos anos, buscado uma compreensão mais profunda sobre esses fenômenos que, ao atravessarem a vida cotidiana, lançam também indagações sobre a nossa prática clínica.

A memória era considerada pelos gregos, na antiguidade, uma identidade divina. A deusa Mnemoyse, mãe das musas protetoras das Artes e da História, tinha o poder de conferir a imortalidade aos humanos. Quando o artista ou o historiador registrava em sua obra imagem, feitos, ações ou palavras de alguém, isso não ficava esquecido, mas tornava-se memorável e, desse modo, um exemplo para as gerações futuras. A importância da memória também se refletia na medicina: o ponto de partida para que um médico pudesse diagnosticar e tratar o paciente de determinada doença era, e ainda o é no tempo de hoje, a anamnese palavra que vem do grego e que se refere à recordação dos fatos e circunstâncias que precederam o momento em que o indivíduo ficava doente (CHAUI, 2000).

Izquierdo (2004), neurocientista que estuda aspectos relativos à memória e ao esquecimento, acredita que a identidade de cada indivíduo está totalmente vinculada às próprias memórias, apoiando-se no pensamento do filósofo e pensador italiano Bobbio (1996, apud IZQUIERDO, 2004) que afirma que "somos rigorosamente aquilo que lembramos" (p. 16). Ainda segundo o autor, a abordagem experimental fundamentada nos fatores que são observáveis no comportamento, e que deram origem ao behavorismo, representada por seu fundador Ivan Pavlov, é a precurssora da moderna biologia da memória. Pavlov pouco se utilizava da palavra memória em seus estudos e acreditava que os reflexos explicavam os comportamentos. No entanto, ele demontrou, com seus experimentos, que gravamos de modo mais eficaz as memórias de grande conteúdo emocional, aquelas que eram consideradas “biologicamente significativas”. (IZQUIERDO, 2004, p. 34).

\footnotetext{
${ }^{2}$ Embora a memória seja um tema bastante estudado pelas neurociências, neste estudo abordaremos os aspectos emocionais relacionados ao tema principalmente do ponto de vista da psicanálise e nesse contexto não nos refirimos ao funcionamento cerebral, o qual é de grande relevância e vem sendo muito pesquisado na atualidade.
} 
O avanço da Neurobiologia e da própria Psicologia, principalmente com o nascimento da Psicanálise e seu desenvolvimento, possibilitou compreensão maior do mundo e das pessoas. Muito além da ideia dos reflexos como determinantes de nossos comportamentos, essa visão permite-nos considerar o estudo da memória e suas relações com o campo emocional em um contexto mais amplo, possibilitando múltiplas abordagens.

Sob essa perspectiva, Bosi (1994, 2003), importante autora em nosso meio, considera a memória segundo a sua função social. Por meio da memória dos mais velhos, é realizada a mediação informal da cultura entre as gerações. Testemunhas orais da memória familiar, política ou ainda do trabalho, os idosos contribuem, assim, para um modo de transmissão cultural mais rico e que, por vezes, difere dos mediadores mais formais (escola, igreja, etc.), que podem refletir um caráter unilateral. Para Bosi (2003), a narrativa é a "via privilegiada para chegar até o ponto da articulação da História com a vida quotidiana” (p. 19), justamente por captar diferentes pontos de vista.

Marcel Proust, na obra clássica Em Busca do Tempo Perdido, tornou antológica a passagem em que o narrador, ao mergulhar um bolinho tradicionalmente conhecido como "madelaine" em uma xícara de chá, recupera as lembranças do sabor de suas manhãs dominicais da infância passada na cidade de Combray, na França. Embora retrate uma visão da sociedade francesa do fim do século XIX, os principais temas da obra são o tempo e a memória. Proust, segundo a visão de Py (2004), era extremamente interessado pelas questões relativas à temporalidade e, no decorrer da narrativa, projetava em seus personagens as mudanças causadas pelo tempo. Porém, Proust apresenta algo de vital importância: Como recuperar o tempo que já se foi? A resposta está na memória. Ele irá falar de um despertar de sensações, que antes estavam adormecidas e poderiam vir à tona frente ao estímulo de um fato por exemplo, por meio do que denominou memória involuntária, ou ainda, o Reencontro do Tempo no qual dá a possibilidade de recuperar o passado, ou o próprio Tempo perdido: “[...] tempo que não existe mais em nós, mas continua a viver oculto no sabor, numa flor, numa árvore, num calçamento irregular ou nas torres de uma igreja.” (PY, 2004, p. 8).

Embora Proust fosse contemporâneo de Freud, não há indicações de que um conhecesse a obra do outro. No entanto, Freud, desde o início de suas primeiras elaborações, deu o recordar e o esquecer, como fenômenos de vital importância na teoria Psicanalítica.

Nos primórdios da psicanálise, Freud (1893/1990) afirmava que as recordações encontradas nos fenômenos histéricos só poderiam ser acessadas sob o estado hipnótico. Assim, a lembrança que formava o núcleo de um ataque histérico era, na verdade, aquela que representava o evento traumático, e a hipótese era a de que, se essa lembrança pudesse ser 
trazida à consciência, ou em outras palavras encontrar uma descarga adequada, ela perderia a capacidade de gerar os chamados ataques histéricos. Em 1899, Freud apresentou a hipótese sobre o fato de que as marcas da memória, existentes no psiquismo, estavam sujeitas periodicamente a um processo de reordenação conforme novas circunstâncias se apresentam. Desse modo, a memória não se faz presente de maneira única, mas se desdobra em vários tempos, resultando assim múltiplos registros.

Posteriormente, no artigo intitulado Recordar, Repetir e Elaborar (1914/1990), Freud, já com a teoria da hipnose abandonada, crê em uma tarefa principal do tratamento psicanalítico nesse sentido, que é desvelar, a partir da associação livre, o que o paciente deixava de recordar. Tratava-se, portanto, de preencher lacunas de recordação, o que só poderia ser possível superando as resistências oriundas da repressão. Nesse artigo, Freud introduz também a ideia da recordação no tratamento psicanalítico que assume a forma de uma atuação, ou ainda da repetição à medida que o paciente não consegue superar as resistências devido aos conteúdos que ficaram reprimidos. Assim, quanto maior a resistência do paciente, mais ele substitui o recordar pelo repetir (acting out). Com essa base, o objetivo do tratamento psicanalítico engloba a possibilidade do paciente passar a recordar ao invés de estar preso à compulsão da repetição.

Desse modo, para Freud, o principal instrumento para ocorrer tal modificação está no manejo da transferência pelo analista, onde é possível substituir a neurose comum pela neurose de transferência, passível então de ser curada pelo trabalho psicanalítico. Freud (1914/1990) afirma que a transferência cria [...] uma região intermediária entre a doença e a vida real, através da qual a transição de uma para outra é efetuada. (p. 201). É, portanto, o caminho da transferência que pode conduzir a elaboração das resistências, fazendo surgir assim as lembranças.

Freud (1937/1990), já ao final de sua vida, publicou o artigo intitulado Construções em Análise, no qual ele analisa as construções e reconstruções que se fazem durante a análise. Ele reafirma que cabe aos pacientes, quando recebem uma interpretação do psicanalista, a confirmação dessas hipóteses, principalmente levando em conta se estas advêm do retorno de uma lembrança de infância que estava reprimida, ou se resultam de sua própria certeza de que tal interpretação está correta.

De início, no artigo, é feita uma analogia entre o trabalho do analista e o do arqueólogo. Nessa comparação, do mesmo modo que o arqueólogo escava um território em busca da reconstituição de uma antiguidade, o analista dedica-se, em seu trabalho, à contrução, ou ainda à reconstrução, a partir das lembranças e das associações do paciente, de 
conteúdos de seu passado que foram esquecidos. Continuando a analogia, o arqueólogo, por vezes, defronta-se com objetos que foram destruídos, cujas partes se perderam ao longo dos anos. No entanto, esse é um ponto que difere o trabalho do analista, que conta com a preservação e permanência dos elementos, mesmo que esquecidos e inacessíveis em um determinado momento (FREUD, 1937/1990).

Assim, nas palavras de Freud (1937/1990): "Depende exclusivamente do trabalho analítico obtermos sucesso em trazer à luz o que está completamente oculto.” (p. 294). Essa construção, baseada no recordar das lembranças, constitui-se, porém, em um trabalho analítico preliminar, que não representa o único caminho a seguir, pois muitas vezes o paciente não consegue recordar os conteúdos reprimidos e, mesmo assim, a análise é efetuada com sucesso, pois é produzida “uma convicção segura da verdade da construção" (p. 300).

Entre os vários autores contemporâneos do campo psicanalítico, devemos destacar as contribuições de André Green (2008). Esse autor aborda os temas relacionados à temporalidade, considerando a problemática que representa a interpretação em um processo analítico do material que contém ligações com o passado do paciente. Nesse ponto, ele concorda com a formulação freudiana que preconiza que todo e qualquer material analítico contém elementos pertencentes a momentos do passado, que se intercalam e são modificados por uma elaboração secundária. Por outro lado, ele também reconhece que as ideias de Freud serão sempre úteis, mas que é necessário considerar os diferentes tipos de pacientes e formas singulares de funcionamento psíquico.

Green (2008) propõe uma concepção psicanalítica de tempo, baseado na necessidade que enxerga da evolução do pensamento psicanalítico nos dias de hoje. Para o autor, se por um lado temos o inconsciente visto como atemporal, como postula Freud, por outro, temos as experiências individuais e inevitáveis da ação do tempo sobre nossas vidas, ou em outras palavras: o processo de envelhecimento. Assim, ele fala de desejos, projetos e fantasias que fazem parte do inconsciente, mas que ao mesmo tempo estão relacionados com uma "reserva de vida.” (p. 224). Esta inclui a esperança e as ilusões representadas, por exemplo, não mais somente na ideia de projetos de algo que queremos realizar, mas de projetos já realizados. Esses fatores podem agir, assim, como facilitadores na tarefa de lidar com as vissicitudes do envelhecimento.

Green (2008), baseado em sua prática clínica, desenvolve, ao falar sobre o processo transferencial que ocorre na análise, uma concepção sobre a qual este não pode ser compreendido como desvinculado do passado e tampouco ser considerado mera repetição deste. Nesse sentido, para o analisando, deve ser proposta uma aproximação da verdade, 
considerando sempre a variação dos quadros psicopatológicos: "O trabalho psicanalítico deve visar a um acordo sobre uma relação possível entre o passado e a experiência de análise, sobrepujando a oposição entre fantasia e realidade, entre analisando e analista.” (p. 220).

É importante, nesse ponto, retomar as contribuições de Salvarezza (1993), principalmente porque esse autor relaciona o processo de envelhecimento com a capacidade de recordar, sob a ótica da teoria psicanalítica. Ao rever o conceito de narcisismo proposto por Freud, Salvarezza (1993) discorda do grande número de autores que consideram o aumento do narcisismo na velhice um fenômeno universal e mesmo constitutivo da velhice. Na verdade, como resultado de um conflito relativo às questões do envelhecimento que se apresentam para o indivíduo, ocorre um aumento do que o autor denomina de interioridade. Nesse processo, o conflito acontece entre o desejo e a impossibilidade de satisfazê-lo, em virtude das condições impostas pela velhice. $\mathrm{O}$ aumento da interioridade possibilitará o acesso às reminiscências, levando à integração do sujeito e favorecendo um processo saudável de envelhecimento.

As reminiscências não ocorrem exclusivamente na velhice, mas seu papel em tal etapa da vida é considerado fundamental. Salvarezza (2003) aponta que essa atividade mental organizada está relacionada ao controle egoico, protegendo os idosos de graus de ansiedade ou depressão. $\mathrm{O}$ acesso às reminiscências possibilita assim a reafirmação da autoestima e o aumento da capacidade de lidar com as perdas, inerentes ao envelhecimento, de modo saudável.

De maneira mais ampla, essa forma de recordar assumiu, principalmente no passado, a função de ligar o passado ao presente relacionado à formação e manutenção de uma identidade grupal. Nas sociedades mais antigas era comum encontrar os velhos contadores de histórias, que narravam, de maneira bastante prazeirosa, acontecimentos, feitos e histórias do passado. É importante também ressaltar que o acesso às reminiscências não guarda uma relação direta com o grau de inteligência ou mesmo, em alguns casos, com a deterioração intelectual decorrente de muitas patologias que podem acometer o indivíduo na velhice. Assim, sem desconsiderarmos a importância do papel dos fatores orgânicos - presentes nas dificuldades em recordar acontecimentos recentes em relação aos mais remotos -, sabemos que de fato, conforme preconiza a teoria psicanalítica, os fatores emocionais determinam o grau de acesso às reminiscências ou, em outras palavras, contribuem para uma determinada recordação se tornar consciente ou não (SALVAREZZA, 2003).

Caso o indivíduo não consiga alcançar o estado de integração, em vez de reminiscências, ele terá uma maneira nostálgica de recordar, segundo a ênfase dada aos 
elementos que considera ter perdido em sua vida e a sensação de que estes, agora, pertencem a outros mais jovens, bem como ao sentimento de que não pode concretizar os desejos, pois, dada a proximidade da morte, não haverá tempo suficiente para essas realizações. A gravidade desse processo e os graus de angústia e ansiedade serão determinados pela estrutura de personalidade que o indivíduo apresenta. Frente a esses sentimentos, são utilizados mecanismos de defesa, sendo a depressão, para o autor, o resultado do fracasso desses mecanismos. (SALVAREZZA, 2003).

Quando relacionamos a capacidade do indivíduo recordar na forma de reminiscências com a possibilidade de integração do ego, não podemos deixar de mencionar as contribuições de Erikson (1972), que foi o primeiro psicanalista a incluir a etapa da velhice em sua análise do desenvolvimento do homem, do nascimento até a morte. A velhice é caracterizada por esse autor como fase da integridade, ou aquela que terá como tarefa a integração egoica, resultado do amadurecimento das fases anteriores. Caso isso não ocorra, o indivíduo enfrentará uma crise expressa por um estado de desespero, principalmente com relação à necessidade de mudanças frente à perspectiva de finitude. Como consequência podem ocorrer estados ansiosos e depressivos, dependendo também das cacterísticas de personalidade de cada indivíduo.

\section{2- Recordação e Integração: Considerações a partir da leitura da Obra de Winnicott}

Ao retomar alguns temas importantes da obra de Winnicott, podemos encontrar inicialmente uma relação entre recordação e integração egoica quando o autor, ao discorrer sobre o desenvolvimento emocional primitivo (1945/2000), fala de um processo de nãointegração primária que constitui a base da desintegração, presente, por exemplo, em pacientes com quadros psiquiátricos. Essa não-integração leva a estados dissociados justamente porque ela pode se apresentar de modo parcial. Porém, é pensando no processo do sonho que ele faz interessante relação entre o recordar e a superação desses estados, ao se referir à forma de auxíliar crianças pequenas que têm sonhos aterrorizantes: "Nesses momentos elas precisam que alguém as ajude a lembrar o que sonharam. Quando o sonho não

é apenas sonhado, mas também relembrado ocorre uma experiência de grande valor exatamente pelo fato de que assim a dissociação perde mais espaço.” (p. 226). 
Em 1956, Winnicott publicou um artigo no qual aponta a influência, na prática analítica, exercida pelas novas descobertas relativas aos cuidados dispensados às crianças. Ao referir-se ao trabalho analítico com pacientes que, em razão de não ter ocorrido uma boa adaptação ao ambiente, desenvolvem um pseudo ou falso eu, Winnicott (1956/2000) contempla os casos tidos como fronteiriços ou as fases psicóticas presentes, segundo ele, na análise de pacientes neuróticos ou normais. Com esses pacientes, devido à falha ambiental precoce, a relação transferencial é vivenciada pressupondo a impossibilidade de considerar o ego uma entidade já estabelecida. Nesses casos, a relação transferencial vivida na análise possibilita ao eu o verdadeiro começar a se manifestar. Esse momento é julgado delicado e importante justamente devido à regressão implícita no processo.

Quando isso ocorre, existe a recomendação para que o analista permita que o passado se torne presente, baseado na ideia encontrada na obra de M. Sechehaye intitulada Realização Simbólica (1947), como refere Winnicott (1956/2000). Desse modo, segundo suas palavras: "Enquanto na neurose de transferência o passado vem ao consultório, neste tipo de trabalho é mais correto dizermos que o presente retorna ao passado, e é o passado.” (p. 396). Esse movimento, que pode ser considerado uma adaptação suficientemente boa do analista, dá ao paciente a possibilidade de integração do ego, ao rememorar as falhas originais e poder sentirse real ao viver seus impulsos. A partir desse momento poderia ocorrer a análise considerada normal do ego em relação aos mecanismos de ansiedade.

A possibilidade de vivenciar uma recordação na situação transferencial é retomada por Winnicott, em 1963, da perpectiva do medo do colapso (Breakdow). O medo do colapso, nesse caso, tem o significado do fracasso de uma organização de defesa e relaciona-se às experiências passadas bem como a aspectos de provisão ambiental do indivíduo. Winnicott (1963/1994) desenvolve a ideia de que o medo do colapso apresentado pelo paciente tem sua fundamentação em um colapso que já aconteceu no passado. Na situação analítica, o medo do colapso pode surgir como um sintoma que, por sua vez, é visto como algo positivo, pois torna o paciente dependente da análise, reforçando o sentimento de confiança.

Esse estado de confiança é o que dá justamente a possibilidade ao paciente de experenciar o colapso original, na situação de análise, por meio da relação transferencial. O autor recomenda que essa noção do colapso já ocorrido deve ser comunicada ao paciente, levando em conta que anteriormente não foi possível uma integração em função da imaturidade do ego no bebê. Assim, Winnicott (1963/1994) enxerga a capacidade de recordar vinculada à experiência vivenciada na análise. 
Quando pensamos na relação existente entre recordação e possibilidade de integração do ego, e de modo mais amplo do próprio Self, torna-se necessário também retomarmos alguns conceitos fundamentais na obra de Winnicott. Primeiramente, devemos considerar que a integração, conforme pontua Winnicott (1958/2001), surge de maneira gradual, como uma tendência natural, a partir de um estado de não-integração do bebê, o que faz com que, por volta de um ano, podemos dizer que de modo geral, a personalidade está integrada. Essa premissa não se aplica, porém, a todas as crianças, pois o processo depende das provisões do ambiente, na forma dos cuidados de uma mãe suficientemente boa. No tratamento psicanalítico, Winnicott (1962/1983, p.154) irá destacar o objetivo que possui em ver o paciente alcançar um estado de integração egoica, à medida que pode ser cada vez mais ele mesmo, afirmando assim suas características individuais:

A força do ego resulta em uma mudança clínica no sentido do relaxamento das defesas, que são mais economicamente empregadas e alinhadas, sentindose o paciente não mais preso à sua doença como resultado, mas livre, mesmo que não esteja livre de sintomas. Em suma, observamos crescimento e desenvolvimento emocional que tinha ficado em suspenso na situação original.

Segundo Abram (2000), embora Winnicott afirme com frequência que existe uma distinção entre ego e self, ela nem sempre aparece de modo claro em sua obra. O self, em termos de desenvolvimento, pode ser compreendido como um potencial que o bebê tem, que, ao entrar em contato com um ambiente suficientemente bom, se expressa em um self total, ou em outras palavras, como núcleo da personalidade. Diz respeito também ao conceito de self verdadeiro em oposição à existência de um falso self (WINNICOTT, 1960/1983), relacionado com a construção, por parte da criança, de relacionamentos falsos que, por meio das introjeções, podem tomar uma aparência real. É apontada a natureza defensiva do falso self, que tem a função de ocultar e proteger o self verdadeiro. O self verdadeiro expressa um modo de sentir subjetivo, que inclui os sentimentos de criatividade e de sentir-se real. 


\section{3 - A Memória Emocional na Psicanálise Relacional}

De acordo com a visão de Winnicott, é importante lembrar que a concepção da formação do Self se dá a partir de uma base relacional, ou seja, justamente da relação mãebebê. Desse modo, conforme pontuam Greenberg e Mitchell (1994), Winnicott constrói um corpo teórico e uma prática, tendo como referência essencial o campo relacional, em uma perspectiva que valoriza a subjetividade e a singularidade do paciente. Ainda segundo esses autores, esse modelo diferencia-se do referencial Psicanálítico proposto por Freud e Melanie Klein, que, ao levar em conta o desenvolvimento emocional, toma como ponto de partida as pulsões instintivas.

Baseando-nos nessa ideia, temos observado que a Psicanálise Relacional (STOLOROV, 2002), desenvolvida principalmente nos Estados Unidos, tem fornecido contribuições importantes para a compreensão dos contextos intersubjetivos presentes na situação de análise, no campo que se convencionou chamar de Escola da Intersubjetividade. Desse modo, consideramos que muitas dessas contribuições vão ao encontro à formação de uma base teórica que acreditamos ser bastante pertinente quando pensamos nas questões sobre as quais queremos refletir no contexto deste estudo, principalmente no que diz respeito ao conceito de memória emocional.

Essa corrente teórica tem suas origens na psicologia psicanalítica do Self, criada por Kohut na década de 1960. Nos anos de 1980, Greenberg e Mitchell (1994, p. 13) elaboraram uma concepção relacional da psicanálise para integrar as visões americanas e inglesas das relações objetais. Esses autores defendem, então, a psicanálise fundamentada em um modelo estrutural-relacional, baseada na importância das relações entre os indivíduos como fundamentais na construção da vida mental, em detrimento do modelo freudiano nomeado como estrutural-pulsional, que tem sua base nas pulsões instintivas.

Orange (1995) é uma autora que, juntamente com Stolorov e Atwood (2002), tem desenvolvido suas concepções no campo da psicanálise baseada no modelo relacional, cuja orientação básica é valorizar a experiência subjetiva do paciente. Amparada nesses fatores, ela considera a importância da ampliação do conceito de memória emocional e suas aplicações ao processo analítico. Esse conceito tem como base a ênfase à importância da compreensão emocional como ponto chave do trabalho psicanalítico, e que deve ser estabelecida entre paciente e analista, para juntos empreenderem um caminho em direção a busca de sentido para o sofrimento que o paciente apresenta. Tal relação pressupõe a participação empática do 
analista que, somente desse modo, consegue, ao proporcionar ao paciente um ambiente terapêutico seguro, favorecer uma nova elaboração de suas experiências, que por sua vez inclui também o movimento de integração do Self.

Essa compreensão emocional, sobre a qual Orange (1995) se refere, traz também implícita a ideia da importância atribuída à memória emocional, que pode ser compreendida como uma forma de recordação baseada no passado relacional e, assim, tanto situações quanto determinados objetos podem produzir emoções, embora nem sempre a compreensão acompanhe a produção desses sentimentos.

Fazem parte também da memória emocional os aspectos não-cognitivos e não-verbais relacionados a experiências pessoais, e que muitas vezes não conseguem garantir sua expressão somente desse modo. Para justificar essa ideia, a autora recorre a autores do campo da filosofia e da linguística que pontuam que "uma experiência inclui muito mais que palavras podem expressar" (ORANGE, 1995, p. 106). Há, muitas vezes, na linguagem uma incompletude, pois ela pode captar somente parte da experiência vivenciada. No entanto, de modo paradoxal, é por meio dela que o presente pode ser investido pelo passado e, na situação analítica, resultar uma articulação na qual o que já foi vivido pode ser ressignificado na época atual.

A memória emocional não deve ser observada sob um ângulo patológico, pois, ao contrário, expressa a humanidade que existe em cada um de nós. Segundo Orange (1995), embora a memória emocional tenha suas raízes relacionadas às primeiras noções do recordar do ponto de vista psicanalítico, ela se difere principalmente quando considera que o conceito de repetir o que não foi elaborado pressupõe uma visão das pessoas de um ponto de vista externo. Nesse sentido, a psicanálise tradicional tem uma visão do modo de entrar em contato com essas lembranças mais relacionadas a fatores negativos (quando fala do acting-out e das resistências, por exemplo). A ideia da memória emocional, por outro lado, considera a experiência subjetiva e valoriza "aquilo que o paciente quer saber e não aquilo que ele não sabe." (p. 114).

A situação analítica, vista desse modo, forma o campo intersubjetivo propício ao trabalho de entrar em contato com as lembranças, mesmo porque também favorece que o paciente, de modo gradual, sinta-se menos constrangido em relação aos seus próprios sentimentos e desejos. De todo modo, é necessário pontuar que, no processo analítico, o valor curativo encontra-se estreitamente relacionado à experiencial relacional de vinculação entre analista e paciente e à mútua dedicação com que se empenham em buscar sentido para os conteúdos que surgem na análise (ORANGE, 1995). 
Orange (1995) aponta também que deve ser feita uma distinção entre a noção de inconsciente e de memória emocional. De modo diferente do inconsciente, que é definido por aquilo que permanece fora da consciência, a memória emocional diz respeito à forma com a qual a pessoa sabe de si mesma ao entrar em contato com suas recordações, o que não pressupõe necessariamente uma compreensão baseada na teoria da repressão freudiana. No entanto, é necessário considerar que a ideia da memória emocional, de modo claro, não substitui a ideia do inconsciente, mas representa uma forma de compreender o fato de que nem sempre tornar consciente aquilo que estava insconsciente mostra-se eficaz com relação à cura de determinado sintoma.

O estudo da memória emocional pode ainda, segundo Orange (1995), contribuir para compreender melhor os fenômenos transicionais postulados por Winnicottt (1951/2000). Ao observar esses fenômenos, é possível enxergar a expressão de uma memória relacional nãorepresentacional. De modo similar a Winnicott (1958/2000), que entendia a ocorrência dos fenômenos transicionais como sinal de um bom prognóstico quanto ao desenvolvimento infantil, a capacidade para vivenciar experiências transicionais pode, nessa linha de pensamento, ser considerada uma forma de memória emocional e também sinalizar o progresso do tratamento.

\section{4 - Os Fenômenos Transicionais}

Abram (2000), ao sistematizar os conceitos fundamentais da obra de Winnicottt, ressalta que até o ano de 1951, quando Winnicottt publicou Objetos transicionais $e$ Fenômenos transicionais (1951), não havia na literatura psicanalítica referências ao espaço, ou ainda ao hiato, como coloca a autora, existente entre os aspectos externos e internos da realidade do indivíduo. Até então, Freud havia desenvolvido o conceito do princípio do prazer que se transforma em princípio de realidade, o que sem dúvida colaborou para maior compreensão do desenvolvimento do bebê, mas que não abordava a questão do processo de transição existente.

Devemos considerar que as ideias que Winnicott (1941/2000) desenvolveu a partir do que denominou de Jogo da Espátula, alguns anos mais tarde deram origem à elaboração do conceito não só dos fenômenos transicionais, como também sobre o brincar, a criatividade e o uso do objeto. Podemos afirmar, nesse sentido, que a interação entre a mãe e o bebê - que 
Winnicott (1941/2000) observa na forma como o bebê usa a espátula e por meio da qual é vivenciada uma experiência em conjunto com a mãe - forneceu a base para que o autor chegasse ao conceito dos Objetos e Fenômenos Transicionais. (ABRAM, 2000).

A partir dessa experiência, Winnicott (1941/2000, p.129) faz uma série de elaborações teóricas. No entanto, no contexto que ora focalizamos, é importante destacar que ele considera terapêutico quando o ambiente pode proporcionar à criança uma experiência que ocorra em toda a sua extensão, ou uma experiência total em relação ao objeto.

Retomando a ideia inicial, Winnicott (1951/2000), ao abordar os Objetos e Fenômenos Transicionais, deixa claro que não é seu objetivo tratar o uso dos primeiros objetos nas relações objetais, seja o punho do bebe ou o primeiro ursinho de brinquedo, mas sim, segundo ele: Meu interesse aqui é a primeira posse, e a área intermediária entre o subjetivo e o que é objetivamente percebido" (p. 318). Nesse sentido, Winnicott refere-se à expressão "Objeto Transicional" e "Fenômeno Transicional" para nomear a área intermediária da experiência entre, por exemplo, o polegar do bebê e o ursinho, estendendo mais tarde a outros fenômenos, como por exemplo, entre o erotismo oral e a verdadeira relação objetal. Winnicott (1951/2000) designa essa terceira área como uma região intermediária da experimentação, e tanto a realidade externa quanto a interna do indivíduo contribuem para a sua existência. $\mathrm{O}$ autor destaca a função dessa área como relacionada a um lugar de descanso para o indivíduo, frente à tarefa de manter as realidades externas e internas, ao mesmo tempo, separadas e também inter-relacionadas.

O objeto transicional que pode ser adotado pelo bebê, e que constitui sua primeira posse não-eu, caracteriza a passagem dele da dependência absoluta que tem da mãe para a dependência relativa, na qual passa a ver a mãe como parte não dela. Existe também uma relação importante entre o objeto transicional e o ato do bebê criar aquilo do qual necessita, pois é desse modo que o objeto torna-se de fato seu. Os objetos, que podem ser concretos (a ponta de um cobertor ou uma bolinha de lã, por exemplo) ou abstratos (uma palavra, maneirismo ou melodia), segundo Winnicott (1951/2000), atuam como defesa contra a ansiedade, especialmente depressiva, da criança.

O papel da ilusão e da posterior desilusão do bebê nesse processo é fundamental, pois nele está a base para que ocorra a elaboração da diferença entre o eu e o não-eu, fundamentais para que a percepção objetiva do bebê possa ocorrer. Assim, o bebê necessita inicialmente acreditar em que ele de fato cria o seio da mãe e a partir daí a função desta é desiludi-lo. A esse respeito, Winnicott (1951/2000), postula que: “A região intermediária à qual estou me 
referindo é aquela que é liberada para o bebê entre a criatividade primária e a percepção objetiva baseada no teste da realidade." (p. 327).

Winnicott (1959/1994), um pouco mais tarde, ao falar sobre O Destino do Objeto Transicional, introduz um ponto de vital importância na sua formulação teórica: a existência de uma terceira área de viver, que denominou naquele momento de vida cultural do indivíduo. Desse modo, consideramos a primeira área relativa à realidade psíquica individual e a segunda como a realidade externa (o mundo que é aos poucos reconhecido como não-eu). Mas a terceira área tem sua origem nos fenômenos transicionais do bebê e relaciona-se às experiências culturais. Para melhor ilustrar sua linha de pensamento sobre o tema, Winnicott (1959, p.48) parte da reação do bebê frente à ausência da mãe. Inicialmente ocorre a ligação com o objeto transicional e, após um determinado tempo, a mãe internalizada se desvanece e o objeto transicional perde seu significado. Do mesmo modo, um adulto em situação de luto pode deixar de lado os interesses culturais e, quando se recupera, passa a se importar novamente, por exemplo, com religião.

Abram (2000), aponta que: "Do ponto de vista do observador, o objeto transicional é um símbolo de um aspecto da experiência de ambiente do bebê.” (p. 258). Com o passar do tempo, o objeto deve ser aos poucos descatexizado, de modo que, mais do que esquecido, ele perca o sentido e torne-se difuso, porque segundo Winnicott (1951), ele se espalha por toda a área intermediária da realidade interna e externa e, desse modo, "sobre todo o campo da cultura." (p. 321). Nesse sentido ainda, a área intermediária da experiência irá constituir, mais tarde, uma área de superposições de experiências comuns, seja no campo da arte, filosofia, religião, e outras.

Em um artigo publicado em 1967, Winnicott discorre sobre a localização do que nomeou de "experiência cultural". Trata-se, segundo ele, de um desenvolvimento da noção dos fenômenos transicionais e de sua continuação direta, a brincadeira. Essa área de superposições de experiências comuns localiza-se no que Winnicott denominou de "espaço potencial: O lugar em que a experiência cultural se localiza está no espaço potencial existente entre o indivíduo e o meio ambiente (originalmente, o objeto) (p. 139). A utilização do espaço potencial inicia-se na relação mais primitiva com a mãe, quando as experiências vivenciadas resultaram um sentimento de confiança por parte da criança que garanta a sensação de permanência e provisão ambientais necessárias. Nessas condições, o espaço potencial será preenchido com o resultado da imaginação criativa do bebê.

Descrita ainda como a terceira área, considerando que existe tanto a realidade psíquica interna quanto o mundo real, o espaço potencial primeiramente vivenciado entre a mãe e o 
bebê - e mais tarde com relação ao indivíduo e a família e o mundo - varia de indivíduo para indivíduo, dependendo das experiências que vão trazer confiança e possibilidade de um viver criativo. Nesse sentido, o lugar, como refere Winnicott (1971/1975), em que permanecemos a maior parte do tempo de nossas vidas torna-se de fundamental importância, pois, ao não se moldar propriamente às características da esfera do comportamento (realidade externa) nem da contemplação (realidade psíquica interna), nos fala de um lugar para viver, e que não pode ser apropriadamente descrito quer pelo termo "interno", quer pelo termo "externo".

Retomando, então, os conceitos expostos anteriormente, vimos que o espaço potencial é produto das experiências individuais desde as relações mais primitivas entre o bebê e sua mãe. Winnicott (1971/1975) pontua que nessa gama de experiências deve existir, de modo ideal, certo grau de confiança na fidedignidade da mãe por parte do bebê, pois somente assim será possível, para a criança e mais tarde para o adulto, tornar esse espaço potencial também uma área de separação, que pode ser preenchido de forma criativa com o brincar e mais tarde com a herança cultural. A esse respeito Winnicott (1971/1975), ressalta que: "valorizamos especialmente o brincar e a experiência cultural; são coisas que vinculam o passado, o presente e o futuro, e que ocupam tempo e espaço.” (p. 151).

Com relação à expansão desses conceitos na clínica contemporânea, Green (2007, p. 36) analisou os conceitos psicanalíticos com os quais trabalha sob a ótica da psicanálise winnicottiana e, nesse sentido, considera a teoria dos fenômenos transicionais a contribuição mais original de Winnicott. Para o autor, os fenômenos transicionais fazem parte dos processos de simbolização e são essenciais para a elaboração psíquica. Como aponta Winnicott (1951/2000), a criação do objeto transicional diz respeito muito mais a utilização que é atribuída ao objeto do que ao objeto em si. Quando se fala em oposição entre fantasia e realidade, objetos internos e externos, criatividade e percepção, o objeto transicional adquire o significado do simbolismo no tempo. Se utilizarmos a figura de uma viagem para falarmos da percepção do bebê do que é totalmente subjetivo para o que é objetivamente percebido, o objeto transicional é o perceptível dessa viagem que indica o desenvolvimento ocorrido a partir da experiência vivenciada.

Green (2007), nessa mesma linha de pensamento, aponta ainda que a figura da viagem empreendida pelo bebê "expressa a qualidade dinâmica da experiência, o que implica em um movimento no espaço, ligado ao tempo." (p. 36). Nesse sentido, o autor afirma que Winnicott (1951/2000), com a teoria dos fenômenos transicionais, desenvolve uma ideia alternativa à teoria freudiana das pulsões, pois esta apresenta uma dimensão dinâmica e também uma relação quanto ao espaço percorrido pela pulsão, desde sua fonte até o objeto ao qual se 
direciona. Ainda, para melhor compreender essa ideia, ele ressalta que o espaço transicional não deve ser entendido somente como uma área intermediária de experiência, ou, como ele denomina, um espaço entre dois, como uma área onde o futuro objeto encontra-se em trânsito, e ao final desse percurso o bebê toma posse dele de um objeto, que por sua vez foi criado à semelhança de um objeto externo real.

Desse modo, o conceito de transicionalidade não deve ser somente utilizado para compreender a dimensão existente entre o interno e o externo. Esse conceito pode ser aplicado também às estruturas intermediárias do mundo interno e, por isso, o autor afirma que "a natureza essencial do eu é transicional." (GREEN, 2007, p. 86).

Embora muitos autores busquem compreender a teoria de Winnicott pela perpectiva da intersubjetividade e esta, de fato, é fundamental. Safra (2009), autor do nosso meio, acredita que ele vai além em suas formulações. Ao considerar a realidade transicional, Winnicott valoriza o que ocorre entre dois sujeitos e que vai além da subjetividade de cada um, constituindo assim o Espaço Potencial um fenômeno que ocorre como experiência compartilhada. Na clínica winicottiana, a experiência é fundamental e a criação do Espaço Potencial entre analista e analisando é justamente o que vai possibilitar que esta experiência aconteça. O conceito de Espaço Potencial contribui também para uma expansão da intervenção clínica, à medida que pode ocorrer, além do consultório, em lugares, por exemplo, como escolas, instituições e comunidades.

Também em nosso meio, Aiello-Vaisberg (2004) tem se dedicado à pesquisa de Enquadres Clínicos Diferenciados à luz da Psicanálise winnicottiana. Desse modo, são realizadas Oficinas Psicoterapêuticas de Criação, constituindo um estilo clínico que vem sendo denominado Ser e Fazer. Compreendendo a idéia de enquadre como a criação de mundos temporários que estão inseridos em um contexto que se configura como espaçostempos de brincar. Nas Oficinas são apresentadas materialidades variadas, como a polpa de papel, as flores e fotografias, resultando, entre outras, em Oficinas de papel reciclado, de arranjos florais e também na Oficina Psicoterapêutica de Cartas, Fotografias e Lembranças, tema do presente trabalho.

Aiello-Vaisberg, (2009) analisa também os distúrbios relacionados ao sono sob a perspectiva da transicionalidade, entendida como uma modificação de estados de consciência vivenciados no tempo e que alternam estados calmos e excitados. Assim, podemos falar de "uma atenção máxima e focada, de natureza operacional, racional e pragmática", (necessária, por exemplo, no trabalho e nas relações sociais) para "uma consciência sensível a amplificada" (p. 148), presente em registros mais sensíveis e afetivos. A autora traça um 
paralelo entre esses estados e os espaços físicos que as pessoas ocupam no exercício da convivência, seja nas praças, vistas como espaços propícios ao dialogo, seja em jardins, compreendidos como: "espaços propiciadores de uma transição entre estados integrados e não-integrados, favorecedores do holding que se daria na vida desperta, permitindo ao indivíduo estar desperto e vigilante, sem estar necessariamente acordado e assombrado por perigos." (p. 148).

\section{5- A Oficina Psicoterapêutica de Cartas, Fotografias e Lembranças}

É importante destacar que a materialidade com a qual trabalhamos nas Oficinas Psicoterapêuticas foi inicialmente determinada como "Cartas, Fotografias e Lembranças". No entanto, observamos em nossa prática clínica a grande quantidade de objetos que os pacientes trazem às sessões. Por esta razão, optamos nesta introdução teórica por falarmos, inicialmente, de forma mais ampla, sobre a interface da psicanálise com objetos de modo geral, e que também inclui as cartas. Em seguida enfocamos a Oficina Psicoterapêutica de Cartas, Fotografias e Lembranças, sua fundamentação teórica, e apresentamos pesquisas que temos desenvolvido com esse enquadre.

Walter Benjamin (1940/1994, p.94), ao traçar a história da fotografia, propõe uma relação entre fotografia e psicanálise à medida que determina que a natureza que fala à câmara não é a mesma que fala ao olhar. Imagens que revelam ações conscientes que são substituídas por outras inconscientes também se contrapõem. Como exemplo, é proposta a imagem de um homem que caminha sem que percebamos sua atitude do momento. Segundo Benjamim (1940/1994, p.94): “A fotografia nos mostra essa atitude através de seus recursos auxiliares: câmara lenta, ampliação. Só a fotografia revela esse inconciente ótico, como só a psicanálise revela o insconsciente pulsional."

Em nosso meio, Frayze-Pereira (2005), à medida que trabalha com as implicações entre arte e psicanálise, traz contribuições importantes ao considerar o estudo dessa ciência uma forma de refletir sobre a relação que o homem estabelece com a cultura. $\mathrm{O}$ autor aborda a dimensão perceptiva da relação com a fotografia em um sentido em que não é possível conhecer todas as suas facetas, ou melhor dizendo, levando em conta aquilo que não se revela por completo de imediato, mas que traz em si a subjetividade implícita. Nesse contexto, a fotografia traz em si a noção de mistério, ou em suas palavras: "convida a fantasia a entrar em cena. A fotografia não explica nada. Ela fascina.” (p. 100). 
Frayze-Pereira (2005) recorre a Barthes (1981) para falar sobre o sentimento doloroso que se apresenta ao observar determinadas fotografias. Ele atribui esse sentimento a uma relação que se estabelece entre o revelado pela fotografia e o que já está morto, designado como o "isto foi", que pertence ao passado e que reflete, por sua vez, a própria dor e vulnerabilidade da humanidade frente à morte. É a partir também desta perspectiva de dor, considerada como uma dimensão fundamental no campo psicanalítico, que Frayze-Pereira (2005) afirma que, entre todas as artes, é a fotografia que mais se aproxima da psicanálise:

[...] assim como na fotografia, o negativo transforma-se, mediante um processo físico-químico, numa imagem-objeto capaz de suscitar em nós recordações e narrativas, na psicanálise observa-se a conversão do nãosentido em sentido (pictogramas ou palavras), sentido que pode gerar novas elaborações. Sem essa transformação simbólica o que resta ao sujeito é a experiência subjetiva da dor como fenômeno que persiste como mal-estar físico-psíquico, como um estado não nomeado, não pensado. (p. 117).

A análise e reflexão sobre a relação que o homem tem com os objetos é um tema bastante frequente também na obra de Safra (1999, 2004). Em A Face Estética do Self (1999), o autor desenvolve a ideia de que "as vivências de um indivíduo e seu estilo de ser constituem-se estéticamente, e o self se constitui, se organiza, se apresenta por fenômenos estéticos.” (p. 24). Os símbolos do self se expressam em imagens que vão formar os objetos de self, refletindo o modo de ser do indivíduo e também os objetos de self localizados na cultura bem como em sua faceta artístico-religiosa. Esses objetos, por sua vez, podem se constituir, em um primeiro momento, como subjetivos e logo após em objeto transicional, caracterizando assim uma primeira forma de posse não-eu.

Em 2004, Safra retorna a esse tema, pontuando que, para uma intervenção clínica poder se realizar por meio de objetos é necessário reconhecer a mensagem que esse objeto traduz, além de compreender o idioma pessoal do paciente. Desse modo, os objetos, para o autor, possuem diversos registros: étnico, estético, ontológico, teológico, social e lírico. O registro étnico diz respeito às características sensoriais e culturais que caracterizam os habitantes de um determinado lugar. O registro estético fala sobre o estilo de ser daquela pessoa. $\mathrm{O}$ ontológico reflete o modo como foi colocada naquele objeto uma concepção sobre a origem do mundo. 
O registro teológico representa o sentido de como colocamos nos objetos a ideia do fim último de nossa existência. O registro social é expresso pelo significado que aquele objeto tem com relação a um determinado grupo. Por fim, o registro lírico que o objeto possui, e que parece mais se aproximar do sentido que acreditamos ter o uso da materialidade que empregamos, é aquele concebido justamente por adquirir significado ao fazer parte da vida da pessoa "[...] adquirindo dessa forma uma ressonância poética." (p. 95).

Para o autor, é na perpectiva do conceito de espaço potencial formulado por Winnicott (1967/1975) que a fotografia, assim como os objetos, pode ser considerada elemento de intervenção e também de investigação psicanalítica. A fotografia é considerada, nesse contexto, um elemento cultural que está diretamente relacionado à memória e que também, desta perspectiva, possui vários registros possíveis. Safra (2009) fala sobre a memória subjetiva relacionada ao sentido biográfico que o indivíduo confere à fotografia. É possível também o registro social, (no sentido de um documento) e o registro de como a fotografia mostra o Real, que vai além do registro subjetivo e social. É exemplo de um registro do Real a expressão poética que pode ser percebida em uma fotografia.

Em nossa experiência, utilizamos a fotografia como meio de intervenção psicoterapêutica no contexto de uma Oficina de Vídeo e Fotografia, dirigida a adolescentes de duas aldeias Guarani, na cidade de São Paulo. A mediação do material fotográfico, e também de vídeo, resultou a realização de um documentário, construído a partir de um roteiro elaborado pelos próprios participantes. Ao final do processo, pudemos concluir que essa forma de enquadre contribuiu para a constituição de um campo emocional que, por sua vez, propiciou o encontro intersubjetivo e também interétnico dos participantes, mesmo levando em conta fatores como as diferenças culturais (BONFIM et al., 2005).

Mamede (2006) propõe em seu trabalho a utilização de objetos concretos, como cartas e fotografias, no atendimento psicoterápico de pacientes internadas na Colônia feminina do antigo Manicômio Judiciário do Estado de São Paulo. A partir dos pressupostos winnicottianos da Consulta Terapêutica, a autora realizou intervenções que possibilitaram auxiliá-las no resgate de sentimentos de dignidade e inserção e, principalmente, de constituição do Self. No entanto, o uso daqueles objetos apresentou também um caráter limitante, pois não conseguiu atingir totalmente a demanda daquelas pacientes.

Volpi (2009), da perspectiva do espaço potencial, ressalta a possibilidade de os objetos, e mesmo de situações do cotidiano, contribuirem para a formação de lugares de repouso e passagem para o indivíduo. Com essa base, é proposto um trabalho que utiliza também a fotografia como elemento mediador na relação grupal de caráter terapêutico ou não. 
Nesse enquadre, os participantes do grupo recebem o convite para que, durante três sessões, tragam fotografias que possuam o sentido de "encontrar sua própria história". Segundo o autor, esse é um enquadre que pode ser utilizado de modo amplo e que, ao utilizar fotografias no trabalho que propõe, permite intensificar as relações no grupo, favorecendo os processos de elaboração e ressignificação do vivenciado.

Ao enfocar a experiência clínica no campo da psicanálise, Soares (2007) relata o atendimento de uma senhora de 73 anos com diagnóstico de demência, em um quadro de progressiva perda de memória e dificuldades de raciocínio. No decorrer do processo, a psicoterapêuta e a paciente descobriram um interesse mútuo no campo da arte, que possibilitou uma linguagem comum frente ao estado de isolamento em que a paciente se encontrava. Desse modo, ela passou a trazer à sessão, de início, livros de arte e, mais tarde, fotografias que representavam diferentes momentos de vida dela.

A partir dos relatos facultados pela intermediação desses objetos, Soares (2007) fez o registro escrito de suas memórias, escrevendo, na primeira pessoa do singular e em tempo presente, uma redação autobiográfica da paciente. Em determinado momento, foi oferecida à senhora esse material, o que intensificou o processo de expansão da comunicação e da confiança no processo terapêutico. Por meio da constituição, do que a autora qualificou como metáfora, ou seja, de uma comunicação intuitiva na relação psicanalítica e facilitada pela intermediação dos objetos presentes na sessão, foi possível observar melhora em relação às dificuldades de memória. Nesse processo, a utilização de objetos favoreceu a conexão de áreas da mente da paciente, que juntamente com a integração de seus sentimentos, permitiu um processo de ligação de seu passado com o presente.

A Oficina Psicoterapêutica de Cartas, Fotografias e Lembranças é baseada em um modo de intervenção psicanalítica que utiliza enquadres clínicos diferenciados à luz da teoria Winnicottiana. Esse tipo de enquadre vem sendo pesquisado por nós no Laboratório de Saúde 
Mental e Psicologia Clínica Social ${ }^{3}$, no âmbito dos projetos APOIAR $^{4}$ e SER e FAZER Oficinas Psicoterapêuticas de Criação ${ }^{5}$.

As Oficinas Psicoterapêuticas têm se caracterizado em importante espaço que privilegia tanto o atendimento à comunidade quanto o desenvolvimento da pesquisa clínica e, nessa perspectiva, a partir de diferentes tipos de materialidades mediadoras, visam oferecer um ambiente terapêutico que possa favorecer o crescimento emocional e o desenvolvimento das potencialidades de cada indivíduo, criando condição de sustentação emocional e recuperação do gesto criativo, podendo assim gerar mudanças.

A apresentação da materialidade mediadora em cada oficina é vista como um elemento facilitador do brincar, podendo ser considerado um paradigma do Jogo do Rabisco proposto por Winnicott (1968/1994). A materialidade que é usada como mediação na comunicação entre o terapeuta e o paciente tem a função de gerar condições para a expressão do gesto espontâneo, fazendo com que o paciente saia de um estado de passividade e possa agir sobre o mundo, recuperando assim a possibilidade de existir de modo criativo no mundo.

Nesse tipo de enquadre se destaca o caráter não interpretativo em que o terapeuta não segue o modelo de "saber sobre o outro", decifrando o que ficou inconscientemente recalcado, mas parte do princípio de que a possibilidade da experiência do encontro inter-humano se fará acompanhar naturalmente da articulação simbólica (AIELLO-VAISBERG; MACHADO, 2003). Assim, nessa proposta de enquadre diferenciado, segundo Aiello-Vaisberg (2006): “A intervenção fundamental neste caso será o manejo ou holding, mediante o qual se exerce um

\footnotetext{
${ }^{3}$ O Laboratório de Saúde Mental e Psicologia Clínica Social está inserido no Departamento de Psicologia Clínica do Instituto de Psicologia da Universidade de São Paulo, sob a coordenação da Profa. Livre Docente Leila Salomão de La Plata Cury Tardivo. O Laboratório abriga os projetos APOIAR e SER e FAZER, com o objetivo de formação, pesquisa e oferta de serviços à comunidade em Saúde Mental.

${ }^{4}$ Atualmente é desenvolvido no APOIAR, sob a coordenação da Profa. Leila Cury Tardivo, um Projeto de Pesquisa/Intervenção Clínica voltado à realização de Oficinas Psicoterapêuticas em Hospitais Psiquiátricos. A compilação de vários artigos sobre esse tema pode ser consultada em Tardivo e Gil, 2008.
}

${ }^{5} \mathrm{Na}$ SER e FAZER, sob a coordenação da Profa. Tânia Aiello-Vaisberg, são desenvolvidas pesquisas no âmbito das Oficinas Psicoterapêuticas de criação com a utilização de diferentes materialidades. Atualmente, são realizadas no Instituto de Psicologia, além da Oficina de Cartas, Fotografias e Lembranças, as Oficinas de Arte do Papel, Arranjos Florais, Conversas e Esculturas, e de Tapeçaria e outros Bordados. 
cuidado à continuidade de ser, que favorece movimentos no sentido da integração pessoal que se encontra no gesto criador." (p. 26).

Devemos destacar ainda o caráter formlessness da materialidade apresentada que, similar a um estado de não-integração, já descrito por Winnicott (1945/2000), favorece o movimento do paciente em relação ao criar/encontrar de forma, portanto, criativa.

No enquadre clínico proposto de Oficina Psicoterapêutica de Cartas, Fotografias e Lembranças, os pacientes recebem o convite para que tragam cartas, fotografias, objetos ou ainda lembranças de qualquer natureza. Os encontros são semanais e têm uma hora e meia de duração. Sobre um cavalete ou mesa, apoia-se um quadro magnético branco que, auxiliado por ímãs, recebe e sustenta os diferentes materiais trazidos em cada sessão. O beiral do cavalete ou a superfície da mesa fornecem ainda a base para que sejam apoiados objetos que não puderem ser afixados no quadro. Após afixar o material trazido para a sessão, os participantes posicionam-se ao redor do quadro, quando, então, é aberto um espaço para falarem sobre as recordações e experiências que estas materialidades suscitam, bem como sobre tantos outros acontecimentos que fazem parte da vida de cada um. Desse modo, no espaço potencial criado, no conjunto, ocorre a manifestação de uma expressão coletiva, mas que conserva também o particular e singular de cada indivíduo.

Ao final da sessão, o quadro magnético é fotografado e a fotografia compõe um álbum que registra a produção do grupo. Durante as sessões o álbum permanece no local e fica disponível aos participantes. Ao serem fotografados novamente pela terapeuta durante a sessão, as fotografias e objetos instituem uma nova lembrança, contribuindo assim para o registro da sessão terapêutica e também, de modo mais amplo, para a construção da história do grupo.

Nessa Oficina, portanto, os participantes trazem lembranças de um passado mais recente ou distante, que são contadas ao grupo. Muitas vezes essas lembranças são mediadas por materialidades concretas: cartas, fotografias e objetos variados, a partir dos quais surgem as recordações.

Segundo Machado et al (2003), os objetos trazidos às sessões podem ser designados como "objetos dramáticos", pois:

[...] provêm da história de vida de cada um e têm o poder de constelar, no aqui e agora, uma experiência emocional significativa do passado [...] esta expressão enfatiza o enraizamento do objeto na trajetória do viver pessoal, 
bem como o fato de virem entretecidos com narrativas de histórias de vida. (p. $68)$.

Ainda segundo as autoras, a partir de articulações teóricas com o pensamento de Politzer (1928/1975) e Bleger (1963/1984), o termo dramático nesse caso é usado em seu justo significado, pois, para Politzer (1928/1975, p. 27), não existe nenhuma conduta na esfera humana que não tenha sentido, e a compreensão desse sentido deve se dar em um contexto que leve em conta a história de cada indivíduo em seu aspecto singular. Esse autor irá utilizar o conceito de drama e, ao falar sobre a vida dramática do homem, ressalta que é justamente essa característica dramática que irá possibilitar um estudo científico.

Por meio desses objetos dramáticos, acontece um mundo transicional, onde o passado (que pode ser recente ou mais remoto) se presentifica. Segundo a observação de Machado et al. (2003, p. 78), o que viabiliza a experiência vivida no passado voltar à vida no presente é o fato desta poder ser compartilhada, do ponto de vista emocional, pelo grupo. Desse modo, ao dar um novo sentido ao passado, favorecido por trocas afetivas que ocorreram no presente, é possível também projetar um futuro de novas perspectivas.

A integração entre a materialidade trazida pelos participantes e a narrativa referente às recordações despertadas dão uma dimensão existencial ao encontro terapêutico, ou em outras palavras, o gesto espontâneo pode ser assim integrado à narrativa. Vale dizer que gesto espontâneo é um termo criado por Winnicott (1960/1983) para designar uma das formas de expressão do Self verdadeiro. Essa integração à qual nos referimos colabora para a sustentação do encontro terapêutico. Nesse contexto, deve ser levado em conta o holding fornecido ao grupo pela presença e disponibilidade emocional da terapeuta que, à medida que acolhe os objetos dramáticos, favorece um campo propício para a troca e elaboração de experiências emocionais. (MACHADO et al, 2003).

Ao longo dos últimos anos temos realizado pesquisas com o enquadre clínico proposto na Oficina Psicoterapêutica de Cartas, Fotografias e Lembranças, tanto no contexto clínico quanto institucional, o que tem gerado publicações de artigos e participações em congressos. A seguir destacamos os trabalhos mais recentes.

A Oficina Psicoterapêutica em questão foi realizada em um hospital psiquiátrico, dirigido a pacientes masculinos na cidade de São Paulo, com o objetivo de criar um espaço de escuta e continência para pacientes internados. Participaram da Oficina quatro pacientes que exerciam a profissão de policiais, em sua maioria apresentando quadro depressivo associado ao uso de álcool. Foram realizados cinco encontros com frequência semanal e duração de uma 
hora e meia. Durante as sessões, os pacientes trouxeram principalmente fotografias e cartas escritas por seus familiares. No transcorrer do processo psicoterapêutico, pudemos observar que a materialidade utilizada propiciou grande envolvimento dos pacientes que, não obstante as condições de internação, mostraram-se motivados em trazer o material e participar do grupo. Ao final das cinco sessões, percebemos os pacientes menos angustiados e menos deprimidos, demonstrando mais confiança na necessidade de tratamento (GIL et al, 2008).

A experiência de realizar a Oficina de Cartas, Fotografias e Lembranças com cinco participantes de idades diversas (entre 16 e 73 anos), resultou um trabalho ocorrido no Laboratório de Saúde Mental e Psicologia Clínica Social do Instituto de Psicologia da Universidade de São Paulo ${ }^{6}$ (GIL; AIELLO-VAISBERG; TARDIVO, 2009), com um grupo que manteve a mesma configuração pelo período de um ano. A partir de uma ilustração clínica que relata a leitura de seu diário por uma participante de 16 anos e as ressonâncias emocionais ocorridas no grupo, foram elaboradas reflexões. Pudemos concluir que a perpectiva inclusiva dessa forma de enquadre, bem como a apresentação da materialidade, permitiu ao grupo a troca de experiências, beneficiando seus membros e favorecendo o encontro terapêutico entre pessoas que, a despeito da idade, puderam se sentir mais integradas e próximas a si mesmas.

Embora o enquadre clínico utilizado na Oficina tenha a perpectiva inclusiva já mencionada, temos observado ao longo dos anos que é grande a procura e aderência ao grupo por pessoas acima de 60 anos. Sob esse enfoque, apresentamos um trabalho referente ao mesmo grupo citado, porém com uma configuração mais recente, formada, nesse caso, por cinco homens com idades entre 60 e 73 anos que apresentavam sintomas de depressão. Esse grupo mantinha, na época do estudo, a mesma configuração há cerca de um ano. Na forma de vinhetas clínicas, foi discutido o processo psicoterapêutico de três participantes, a partir do convite para que os pacientes trouxessem cartas, fotografias ou objetos as sessões. (GIL; AIELLO-VAISBERG; TARDIVO, 2009).

Um dos participantes, com 70 anos de idade, que apresentava grande sofrimento pela morte abrupta do filho, pôde, após seis meses de participação, começar a trazer às sessões fotografias do filho e, com o apoio do grupo, passou a montar durante as sessões, um álbum referente a várias fases da vida do filho. Do mesmo modo, outro participante de 60 anos que

\footnotetext{
6 Desde o seu início, em 2003, o grupo tem se configurado de diferentes formas com relação aos participantes. Desse modo, este trabalho e também o relatado na sequência referem-se a fases distintas do mesmo grupo, sendo que alguns pacientes permaneceram no grupo e outros saíram, dando lugar a novos participantes.
} 
se angustiava muito com diversas mudanças em sua vida (a morte da mãe e a mudança de casa) pode elaborar melhor esses conteúdos a partir de fotografias que retratavam sua casa antiga e também a nova moradia, além de cartas que havia recebido de sua mãe. Por fim, o terceiro participante, com 60 anos de idade, bastante deprimido após a amputação de uma perna devido a diabétes, aceitou o convite de outro integrante para participar do coral, sendo marcante a sessão na qual ele traz um convite para que o grupo fosse assistir a ele na apresentação no final do ano (GIL; AIELLO-VAISBERG; TARDIVO, 2009).

Passaremos a seguir, a apresentar os dados da presente pesquisa inédita desenvolvida com outro grupo, os quais deram origem a essa tese de Doutorado. 


\section{CAPÍTULO II - JUSTIFICATIVAS E OBJETIVOS}

A partir das leituras e do contato com os aportes dos autores que fundamentam a introdução teórica desse estudo, vimos que, nos últimos anos, o Brasil passou a apresentar um fenômeno antes observado somente em outros países: a aceleração do envelhecimento populacional e o consequente aumento da expectativa de vida. Essa realidade tem gerado, cada vez mais, forte impacto no âmbito social, econômico e também na área da saúde. Na atualidade, a ênfase da análise das políticas públicas ainda prioriza o adoecimento físico (VERAS, 2009), mas sabemos que esse impacto se faz sentir também no campo da saúde mental, por exemplo, com o aumento dos índices de quadros psicopatológicos entre os idosos (LEBRÃO; LAURENTI, 2005).

Esse panorama, por sua vez, evidencia a carência, principalmente na rede pública, de equipamentos e profissionais aptos a oferecer o cuidado necessário à saúde mental do idoso e, de modo geral, que venham a contribuir para a melhoria da sua qualidade de vida. Torna-se necessário, no campo da psicologia clínica, o desenvolvimento de novos modelos e propostas que possam, nesse contexto, ser implementados com o objetivo de oferecer a atenção psicológica essencial ao idoso, tanto no sentido da intervenção como da prevenção (TARDIVO, 2008, 2009, 2010).

Por outro lado, temos observado também que, de modo geral, muitas pessoas apresentam dificuldades em lidar com as transformações de suas vidas em decorrência do envelhecimento, não conseguindo realizar mudanças, muitas vezes necessárias. Além disso, há também, em muitos casos, vivências relacionadas ao preconceito e à exclusão social que podem gerar um intenso sofrimento psíquico. Notamos, portanto, que, embora exista a demanda pela atenção clínica, existe também, de modo geral, dificuldades por parte do idoso em procurar e aderir à psicoterapia (GIL, 2005).

Tais dificuldades estão relacionadas, como é o caso de idosos com depressão, com quadros subdiagnosticados e que não são encaminhados adequadamente, como vimos em trabalhos anteriores (Gil, 2005; TARDIVO, 2008, 2009, 2010). No entanto, muitas vezes os enquadres mais tradicionais que preconizam atendimentos individuais e de longa duração não atendem à essa demanda e dificultam, ou mesmo impedem, a aderência ao processo psicoterapêutico. Alguns estudos têm apontado para propostas terapêuticas em grupo e/ou realizadas de forma breve que se mostram bastante eficazes quando dirigida a idosos, levando 
em conta também sua adequação aos equipamentos disponibilizados pela rede de saúde pública (GIL, 2005; ALTMAN et al, 2008; SCHWARZ, 2009)

Apresentamos neste estudo o método psicoterapêutico desenvolvido na Oficina de Cartas, Fotografias e Lembranças. O enquadre nela proposto foi utilizado com outros grupos, e pudemos observar sua potencialidade mutativa, (GIL; AIELLO-VAISBERG; TARDIVO, 2008, 2009) o que nos levou, na presente pesquisa, a aprofundar o estudo e ampliá-lo, dirigindo-o à população idosa.

Ao realizarmos o levantamento bibliográfico necessário para a fundamentação teórica deste estudo, entramos em contato com o trabalho de diversos autores que têm, principalmente nos últimos anos, pesquisado e escrito sobre as questões emocionais relacionadas ao idoso. No entanto, notamos que existe ainda uma carência de estudos que contribuam para maior compreensão clínica do envelhecimento, principalmente sob a luz dos conceitos psicanalíticos.

A partir do acima exposto, tivemos como objetivos na pesquisa:

1 - Apresentar a Oficina de Cartas, Fotografias e Lembranças como proposta de método psicoterapêutico dirigido a idosos em um enquadre grupal.

2- Estudar os alcances desse método psicoterapêutico com relação ao grupo que a ele se submeteu.

3- Apresentar o estudo das vivências emocionais dos idosos que participaram da pesquisa a partir dos instrumentos empregados, estudando a viabilidade de realizar avaliações psicológicas e psicodinâmicas com essa população.

4 - Compreender as vivências emocionais presentes na proposta terapêutica dirigida ao grupo, enfocando de forma especial àquelas relacionadas à recordação e transicionalidade. 


\section{CAPÍTULO III - O PERCURSO METODOLÓGICO}

Para apresentar o nosso percurso com relação ao metodo empregado, vamos, inicialmente, discorrer sobre a utilização do método clínico em pesquisas. Destacamos, nesse sentido, o aporte teórico oferecido por José Bleger (1963/1984), principalmente com relação ao conceito de campo de conduta, e que também contribuirá, posteriormente, para a análise dos dados obtidos na pesquisa.

Em seguida, será abordado o modo como se deu o contato com a instituição onde o trabalho foi realizado bem como com os participantes da Oficina psicoterapêutica. Nesse momento, também nos deteremos na descrição das etapas do processo e dos instrumentos utilizados, finalizando com os aspectos éticos relativos à pesquisa.

\section{1- Considerações acerca do Método Clínico}

Utilizamos neste estudo o método clínico em pesquisa, fundamentado na observação qualitativa dos fenômenos estudados. O método clínico propõe-se a observar os fenômenos de modo independente de sua frequência, com ênfase na forma como ocorrem, ou seja, no processo. Desse modo, o objetivo da pesquisa qualitativa consiste em obter dados descritivos de uma situação, o que pressupõe o contato direto do pesquisador com o fenômeno estudado, da forma como é proposta nesta pesquisa (LUDKE; ANDRÉ, 2006).

A esse respeito, Tardivo (2007), apoiada nos pressupostos de Bleger (1963/1984), acrescenta que a Psicologia Clínica deve ser compreendida como ciência humana, pois objetiva o acesso à conduta do homem. Embora a pesquisa no campo da psicologia clínica tenha como objetivo a compreensão do fenômeno humano, a busca de sentido para as condutas não pressupõe, necessariamente, a determinação de suas causas. A concepção de ciência como um processo que é construído, e não composto de verdades já consolidadas ou prontas, faz pensar no conhecimento e nos instrumentos utilizados para entrar em contato com ele, como um sistema complexo e que está sempre em contínua transformação.

Turato (2004), ao falar sobre o método qualitativo em pesquisa, apresentou em um artigo a definição do que denominou de metodologia clínico-qualitativa, na qual esse projeto se insere: 
É o estudo e a construção dos limites epistemológicos de certo método qualitativo particularizado em settings de Saúde, bem como abarca a discussão sobre um conjunto de técnicas e procedimentos adequados para descrever e compreender as relações de sentido e significados dos fenômenos humanos referidos neste campo. (p. 43).

$\mathrm{O}$ autor ressalta que esse tipo de abordagem metodológica obedece ao modelo fenomenológico em que são valorizadas as angústias e ansiedades existenciais dos participantes do estudo. Nesse sentido, o pesquisador deve valorizar um posicionamento denominado de face a face, com ênfase nas trocas afetivas, na escuta da fala do sujeito e também nos aspectos globais da linguagem corporal e do comportamento durante o contato terapêutico; sendo assim que foi mantido o contato entre a pesquisadora e terapeuta nas Oficinas (TURATO, 2004).

Além das atitudes de caráter existencialista e clínico, é considerada também, como pilar dessa metodologia clínico-qualitativa, a compreensão do ser humano pautada nos referênciais teóricos da psicanálise. Isso se deve, principalmente, porque, por meio desses pilares, é possivel, segundo a visão do autor, acolher as angústias e as ansiedades existentes e promover, assim, a valorização dos aspectos emocionais psicodinâmicos mobilizados na relação com os sujeitos em estudo. De modo mais amplo, trata-se de "buscar interpretar sentidos e significações trazidas por tais indivíduos sobre múltiplos fenômenos pertinentes ao campo do binômio saúde-doença [...] (TURATO, 2004, p. 44).

Nessa perspectiva, é importante salientar que este é um trabalho de Psicologia Clínica que utiliza um referencial psicanalítico. Claude Revault d'Allones (2004) propõe uma reflexão crítica sobre o procedimento clínico. Nesse percurso, ele considera que a dimensão social é parte integrante da psicologia clínica e, consequentemente, também do método clínico, pois considera a psicologia clínica objeto de uma demanda social.

Buscando caracterizar o procedimento clínico, o autor ressalta a importância da demanda nesse processo. Expresso de modos diversos - seja por um indivíduo, seja por um grupo, ou ainda, em alguns casos, pelo próprio pesquisador - Revault d'Allones (2004) aponta que o procedimento clínico "inicia seu trabalho no espaço aberto pela demanda, que ele analisa, estrutura e instrumentaliza." (p. 23). Em nosso estudo, a importância da demanda como aspecto fundante do procedimento clínico e que, ao mesmo tempo, cria espaço para que este aconteça, se traduz na forma como os participantes do grupo aderiram à oficina psicoterapêutica, não obstante termos enfrentado algumas dificuldades ao longo do processo. 
Para o autor, o procedimento clínico é interpessoal e, por essa razão, é também o lugar da ocorrência de fenômenos transferenciais. Dessa perspectiva, o autor aproxima-se dos conceitos psicanalíticos a partir da importância que atribui à implicação do psicólogo nesse processo. Ele destaca também a ideia da relação que se estabelece entre uma ou mais pessoas e, assim, o objetivo de qualquer procedimento clínico é "compreender a dinâmica e o funcionamento psíquico próprios a uma pessoa em sua irredutível singularidade; próprios a várias pessoas, grupos ou categorias de pessoas, segundo certas variáveis: a história pessoal, a estrutura da personalidade, as situações" (REVAULT d'ALLONES, 2004, p. 25). Essa questão sinaliza a importância de dois fatores fundamentais no acontecer clínico presente em nosso estudo: o encontro inter-humano e a busca da singularidade.

O método psicanalítico é considerado aquele que privilegia o sentido emocional das condutas, considerando-as em seu sentido singular e único, contextualizadas social, política e culturalmente. Assim, o fundamento do método psicanalítico é a certeza de que não existem limites para a compreensibilidade do fenômeno humano (BLEGER, 1963/1984). A aceitação desse pressuposto leva a uma metodologia que enxerga a produção de conhecimento necessariamente integrada à intervenção. Essa produção de conhecimento ocorre em um campo inter-humano, em que a clínica e a pesquisa acontecem ao mesmo tempo (AIELLOVAISBERG, 2004, p. 95).

Silva (1993) pressupõe que na utilização do método psicanalítico a relação sujeitosujeito se dê permeada pelo inconsciente de cada um. Para a autora, "trazer à tona esse nível submerso, essa subjetividade e relacioná-la com o nível da superfície, constituem o complexo e delicado trabalho da psicanálise" (p. 17). Assim, para a configuração do método como psicanalítico, a autora recomenda que não se tenha uma teoria ou resposta anterior à investigação, mantendo uma postura de receptiva curiosidade na relação estabelecida.

Para Herrmann (2004), “a Psicanálise é o método interpretativo em ação, não uma teoria" (p. 48). Assim, a psicanálise possui como método de investigação a interpretação psicanalítica. O autor, ao comparar os conceitos psicanalíticos aos fotogramas de um filme, esclarece que, se analisados quadro a quadro, provavelmente o enredo se mostrará pouco esclarecido. Porém "é o método em ação que os põe em movimento" (p. 82). Para o autor, o ponto de união entre a clínica e a pesquisa localiza-se justamente no método psicanalítico.

Quando utilizamos o método psicanalítico em pesquisa, a elaboração do acontecer clínico se dá por meio da interlocução com outros autores desse campo. Assim, apresentamos ao longo da introdução muitos dos aportes teóricos de Winnicott, autor cujas ideias nos acompanham no percurso deste estudo. Nesse contexto, identificamos também, na obra de 
José Bleger (1963/1984), conceitos que nos auxiliam tanto na fundamentação do método clínico quanto na elaboração teórica a partir dos dados obtidos na pesquisa.

Para Bleger (1963/1984), o método clínico relaciona-se a um estudo realizado de modo detalhado e profundo, baseado no contato e na observação direta do pesquisador com o participante da pesquisa, e, em contexto mais amplo, "a Psicologia Clínica é sempre o campo e o método mais direto e apropriado de acesso à conduta dos seres humanos e à sua personalidade" (p. 169). A conduta, segundo a visão do autor, é tratada como fenômeno central na psicologia e deve ser compreendida como toda e qualquer manifestação humana. Embora seja unitária, sua expressão se dá concomitantemente nas áreas do corpo, da mente e da ação sobre o mundo externo, podendo haver, na sua manifestação, o predomínio de uma área sobre outra. Concebido como um ser social, o homem, em seu percurso de vida, só pode ser compreendido se levarmos em conta o seu contexto social, cultural, histórico e político.

É baseado na leitura de Politzer (1928/1975) que Bleger (1963/1984) faz o que consideramos uma de suas mais fundamentais observações quanto à conduta: "Toda conduta, no momento em que se manifesta, é a 'melhor' conduta, no sentido de que é a mais ordenada e melhor organizada que o organismo pode manifestar nesse momento e é a que pode regular a tensão no máximo possível para essas condições.” (p. 144). Frente a tensões várias, a personalidade mostra-se sempre a mais integrada e organizada possível e o sintoma é considerado, nesse sentido, a melhor conduta possível do organismo.

Esse conceito fornece uma concepção de homem que deve ser visto, como postulado por Bleger (1963/1984), sempre como um ser social e concreto, em permanente interação com o outro, mas que necessita ser também compreendido em sua singularidade. Em relação aos participantes de nosso estudo, no caso os idosos, essa visão nos conduz a uma postura de aproximação compreensiva, em que buscamos reconhecer a pessoa que vivencia tal etapa da vida de forma única e singular.

Nessa mesma perspectiva, para Bleger (1963/1984), toda conduta ocorre em um campo. O conceito de campo foi elaborado com o objetivo de, ao obedecer a um rigor metodológico, buscar delimitar uma situação mais ampla para, assim, estudar os fenômenos de modo mais preciso. A noção de campo diz respeito "à situação total, considerada em um dado momento, quer dizer, é um corte hipotético e transversal da situação.” (p. 37). No entanto, esse corte é hipotético, pois, devido a sua natureza dinâmica, o campo está sempre em constante modificação e, consequentemente, não se repete em sua manifestação, ou seja, possui um caráter singular e original. 
A conduta pode ser compreendida assim, dentro desse contexto, como uma modificação do campo e não somente como manifestações de conteúdos internos ou respostas a estímulos externos. Bleger (1963/1984, p. 38) aponta a existência do campo ambiental, que diz respeito ao conjunto de "elementos, condições e acontecimentos" compreendidos de forma objetiva. Ele fala também do campo psicológico, relativo à configuração que o campo ambiental tem em um determinado momento e o campo de consciência que pode ser compreendido, segundo o autor, como "a configuração que tem o campo ambiental para a conduta consciente". Existe uma vinculação entre os campos, que segundo o autor, "contribui para que no campo ambiental presente existam elementos que ativam seu passado e o podem, além disso, situar prospectivamente num acontecimento futuro." (p. 41).

Destacamos o conceito de campo $^{7}$ como parte da orientação metodológica desse estudo, pois posteriormente, ao analisar o acontecer clínico relativo à Oficina Psicoterapêutica, nosso objetivo é utilizar esse conceito para identificar campos psicológicos não conscientes, a partir do que foi vivenciado nas sessões. Lembramos que esse mesmo conceito foi utilizado por Tardivo (2007) quanto à orientação relativa ao método empregado em seu trabalho, onde retrata o adolescente e o sofrimento emocional dos jovens na atualidade. Em sua pesquisa, a autora procurou delimitar o campo relativo às vivências emocionais de jovens indígenas aculturados do Amazonas, procurando conhecer o sentido da conduta de jovens em um contexto de violência e atos suicidas.

Aiello-Vaisberg e Machado (2008) realizaram um trabalho em que articulam a Teoria dos Campos, proposta por Fabio Hermann, com o conceito de conduta sistematizado por Bleger (1963/1984). As autoras apontam que o conceito psicanalítico de conduta mostra-se apropriado para apreender os campos presentes em qualquer manifestação, seja ela individual ou grupal, em um sentido vivencial e não representacional, cuja meta é possibilitar modificações clínicas. Pontuam, também, que a percepção do campo vivenciado tem o efeito de uma ruptura desse mesmo campo e, consequentemente, pode ser modificada a conduta.

Ainda nesta mesma linha metodológica, vale destacar o estudo realizado por Camps (2009), com o objetivo de investigar psicanaliticamente a potencialidade mutativa de oficinas de teatro espontâneo no atendimento a jovens em fase de escolha profissional. Por meio das

7 Utilizamos neste trabalho o conceito de campo a partir da articulação teórica de Bleger (1963/1984). No entanto, embora não tenha sido neste momento focalizado por nós, sabemos da relevância da criação da Teoria dos Campos por Fabio Hermann e a grande contribuição que este autor deu a área da Psicanálise. Desse modo, remetemos o leitor à obra de Hermann, no sentido de uma ampliação e aprofundamento do tema. 
narrativas das sessões, a autora buscou identificar campos psicológicos-vivenciais inconscientes e suas transformações. Ao final do processo, foi constatado que o enquadre clínico utilizado contribuiu para a criação de um novo campo denominado brincante, onde os jovens puderam experimentar ações mais criativas, sentindo-se assim mais próximos de sí mesmos.

\section{2- Participantes e Procedimentos}

Participaram do estudo seis pessoas, um homem e cinco mulheres, na faixa etária entre 65 e 79 anos. Todos iniciaram o processo relativo ao estudo, no entanto após a quinta sessão, o participante do sexo masculino, de 65 anos de idade, faleceu em razão de um enfarte, mas as demais continuaram até o final do processo. Todos eram moradores de uma cidade do interior de São Paulo, com graus de escolaridade de nível fundamental e médio, à exceção de uma participante que era analfabeta. De acordo com a entrevista inicial, não havia histórico de quadros psiquiátricos graves ou ainda doenças incapacitantes. Os participantes pertenciam a um grupo da terceira idade, onde lhes eram oferecidos, semanalmente, atividade física, artesanato, coral e dança cigana. Além disso, eram realizados mensalmente passeios a locais de interesse do grupo, bem como bailes da terceira idade.

O interesse da coordenação do grupo da terceira idade em oferecer um trabalho psicoterapêutico aos participantes originou-se da constatação de que, de modo geral, muitos idosos apresentavam queixas e sintomas relacionados à depressão e tinham dificuldades em procurar e aderir a um tratamento. Inicialmente comparecemos a uma reunião que ocorria semanalmente e que contava com todos os idosos que participavam das atividades oferecidas. Explicamos o objetivo do trabalho, além da duração e local de sua realização, e fizemos o convite para participação de até oito integrantes na Oficina Psicoterapêutica de Cartas, Fotografias e Lembranças.

Foram realizadas duas entrevistas individuais com os participantes e na ocasião aplicados os instrumentos: WHOQOL-BREF - Inventário da Organização Mundial da Saúde em sua forma breve, Inventário Beck de Depressão - BDI e uma técnica projetiva, o SAT Teste de Apercepção para $\operatorname{Idosos}^{8}$. Em seguida, iniciamos o processo psicoterapêutico em

\footnotetext{
${ }^{8}$ Conforme o que determina o Conselho Federal de Psicologia (CFP) - resolução 002/2003, o SAT encontra-se em processo de análise quanto a sua validade científica, e aguarda parecer final para sua utilização na clínica. No entanto, seu uso está aprovado no âmbito da pesquisa.
} 
uma forma breve, com a realização de 16 sessões semanais de uma hora e meia de duração cada, da Oficina Psicoterapêutica de Cartas, Fotografias e Lembranças. As sessões ocorreram no local onde funciona o grupo da terceira idade. Ao final do processo, realizamos uma nova entrevista individual com os participantes, quando foram reaplicados os mesmos instrumentos da entrevista inicial, com exceção do SAT. Consideramos que a reaplicação desse instrumento após 16 sessões não seria interessante devido à proximidade das duas aplicações, pois o período recomendado, quando se trata de retestes com técnicas projetivas, é de um ano (TARDIVO, 2009).

A aplicação dos inventários, instrumentos estes mais objetivos, tiveram a finalidade de complementar os dados da entrevista inicial com relação à qualidade de vida e depressão. A reaplicação dos inventários ao final do processo objetivou, principalmente, evidenciar possíveis mudanças de forma a ampliar a discussão quanto aos alcances da proposta da Oficina Psicoterapêutica. O SAT foi utilizado para favorecer a comunicação com os participantes e auxiliar na compreensão dos aspectos psicodinâmicos, os quais foram discutidos com eles na entrevista final.

A seguir, especificaremos melhor as etapas do processo, bem como os instrumentos utilizados.

\section{1 - Entrevistas Iniciais}

Inicialmente, foram realizadas duas entrevistas individuais com os participantes. A primeira, conduzida de modo semidirigido, objetivou estabelecer um rapport além de explicitar objetivos e procedimentos, e iniciar o processo compreensivo, ou seja, conhecê-los e conhecer a história de vida deles. Foi nossa meta, portanto, obter os dados pessoais e outras informações que os pacientes julgassem relevantes, bem como a motivação que cada um apresentou para participar do processo.

Às pessoas que aceitaram participar, foram entregues os termos de consentimento livre e esclarecido. Elas foram informadas adequadamente do objetivo do estudo e sobre o fato de não haver custo financeiro, bem como lhes foi assegurado sigilo com relação aos dados e o direito às entrevistas devolutivas de todo o processo. Foi solicitada autorização para uso dos dados coletados mediante assinatura do Termo de Consentimento Pós-Informação (anexo A).

Na segunda entrevista foram aplicados os instrumentos: WHOQOL-BREF - Inventário de Qualidade de Vida da Organização Mundial da Saúde - Forma Breve, Inventário Beck de 
Depressão - BDI. Na mesma entrevista foi aplicado o SAT - Teste de Apercepção para Idosos, e foi possível mostrar todas as pranchas nessa mesma sessão. Os instrumentos foram utilizados na ordem de aplicação descrita, sabendo os objetivos do seu emprego e tendo acesso aos dados, de forma compreensível aos participantes. As entrevistas e as sessões da Oficina não foram gravadas, e o relato foi registrado por escrito após cada sessão.

\section{WHOQOL-BREF - INVENTÁRIO DE QUALIDADE DE VIDA DA ORGANIZAÇÃO MUNDIAL DE SAÚDE - FORMA BREVE ${ }^{9}$ (ANEXO C)}

O Professor Marcelo Pio de Almeida Fleck e colaboradores (2008) representam o grupo WHOQOL no Brasil e coordenam diversas pesquisas sobre qualidade de vida. O WHOQOL-100 é composto de 100 questões que avaliam 6 domínios: Físico, Psicológico, Nível de Independência, Relações Sociais, Meio Ambiente e Espiritualidade/Crenças Pessoais. Já o WHOQOL-BREF é uma versão abreviada com 26 questões que obtiveram os melhores desempenhos psicométricos, extraídas do WHOQOL-100. A versão abreviada é composta por 4 domínios: Físico (Domínio 1), Psicológico (Domínio 2), Relações Sociais (Domínio 3) e Meio Ambiente (Domínio4).

Os instrumentos WHOQOL estão atualmente disponíveis em 20 idiomas. A versão em português (Brasil) do WHOQOL-100 e WHOQOL-BREF foi realizada segundo a metodologia preconizada para a versão desse instrumento, tendo sido realizado o teste de campo em 300 indivíduos para cada um dos dois instrumentos. As características psicométricas preencheram os critérios de desempenho exigidos: consistência interna, validade discriminante, validade convergente, validade de critério, fidedignidade de testereteste. A necessidade de instrumentos curtos que demandassem pouco tempo para preenchimento, mas com características psicométricas satisfatórias, fez com que o Grupo de Qualidade de Vida da OMS desenvolvesse uma versão abreviada do WHOQUOL-100, o WHOQOL-BREF. (FLECK et al., 2008).

No WHOQOL-BREF constam 26 questões, das quais duas são gerais e as demais representam cada uma das 24 facetas que compõe o instrumento original. Assim, diferentemente do WHOQOL-100, em que cada uma das 24 facetas é avaliada a partir de 4

\footnotetext{
${ }^{9}$ http://www.ufrgs.br/psiq/whoqol.html - Recuperado em 10 de Maio de 2008
} 
questões, no WHOQOL-BREF é avaliada por apenas uma questão. Os dados que deram origem à versão abreviada foram extraídos do teste de campo de 20 centros em 18 países diferentes.

Quanto à aplicação, o WHOQOL-BREF pode ser autoadministrado, assistido ou aplicado completamente pelo entrevistador. Nos casos de assistência na aplicação, é preciso dar esclarecimentos em algumas questões. O instrumento é completamente aplicado pelo entrevistador principalmente nos casos em que o participante é analfabeto ou portador de condições clínicas que o impeçam de se submeter ao instrumento de modo independente (FLECK et al, 2008).

No caso do presente estudo, optamos por aplicar o instrumento em cada participante, pois além de uma das participantes ser analfabeta, o contato estabelecido durante a aplicação poderia favorecer a comunicação com o grupo. Empregamos esse instrumento somente em sua forma breve. As folhas de aplicação como apresentadas no site bem como as instruções encontram-se na íntegra, no anexo C.

\section{INVENTÁRIO BECK DE DEPRESSÃO - (BDI)}

Segundo Cunha (2001), o Inventário Beck de Depressão foi desenvolvido por Aaron T. Beck e colegas em 1961, para constituir uma abordagem objetiva de medida das manifestações comportamentais da depressão. O interesse era criar um instrumento que avaliasse a profundidade da depressão, de forma padronizada, consistente e econômica, e que fosse de grande utilidade no campo da pesquisa. Os itens desse Inventário vieram, primeiramente, de observações sistemáticas de atitudes características e sintomas de pacientes deprimidos, feitas no curso de sua trajetória clínica. Beck selecionou um grupo de atitudes e sintomas que lhe pareceu específico para esses pacientes deprimidos, e que era consistente com descrições da depressão contidas na literatura psiquiátrica. Com base nessa seleção, ele chegou a um Inventário composto de 21 categorias.

Cada categoria de sintomas e atitudes descreve uma manifestação do comportamento desses pacientes e, inicialmente, consistiam de séries de quatro ou cinco afirmações autoavaliativas que depois foram simplificadas para quatro. As afirmações foram ordenadas de forma a refletir a gravidade do sintoma (de neutro até máximo), e cada uma recebeu valores numéricos de 0-3 para indicar o grau de severidade do sintoma. As categorias de sintomas e atitudes escolhidas por Beck foram: humor, pessimismo, senso de fracasso, 
insatisfação, sentimentos de culpa, expectativa de punição, autoestima, autoacusação, ideias suicidas, choro, irritabilidade, afastamento social, indecisão, mudança na imagem corporal, dificuldade no trabalho, insônia, fatigabilidade, anorexia, perda de peso, preocupações somáticas e perda da libido (CUNHA, 2001).

Entre os trabalhos que utilizaram a escala Beck de Depressão com idosos, destacamos o estudo de Trentini et al. (2006), que consideram que o BDI tem sido amplamente utilizado para demonstrar a prevalência da sintomatologia depressiva em amostras clínicas e nãoclínicas. Partindo da hipótese de que, no idoso, o escore total do Inventário de Depressão Beck pode estar influenciado pela maior pontuação na subescala de queixas somáticas e de desempenho em decorrência do impacto do processo de envelhecimento e das doenças clínicas, eles buscaram verificar a existência de diferenças entre as respostas dos adultos e dos idosos na subescala Queixas Somáticas e Desempenho. Comparando os dados de adultos e idosos, os autores consideram que respostas positivas na subescala Queixas Somáticas e Desempenho do BDI devem ser cuidadosamente avaliadas entre sujeitos idosos. O fator idade, seja pelo envelhecimento ou devido a várias doenças, pode trazer sinais que não são necessariamente sintomas de depressão maior.

Tardivo (2009) realizou uma pesquisa sobre Qualidade de Vida e Depressão em idosos de São Paulo - com a participação de 102 idosos na faixa etária entre 60 e 99 anos, dos quais 47 fizeram parte do grupo controle (sem depressão) e 55 do grupo experimental (com depressão) - e observou a existência de correlação entre resultados do BDI e do WHOQOLBREEF, indicando que as pessoas com depressão têm a qualidade de vida mais comprometida que as pessoas sem depressão. Nesse estudo foram encontrados dados que também indicavam que os idosos que vivem em casa; apresentavam mais depressão do que os asilados.

Cunha (2001) traduziu e validou a Escala Beck no Brasil. Assim, empregamos essa forma (como autorizado em nosso meio). Foi usada a folha de respostas com 21 itens que acompanha o manual que traz os estudos de validação na população brasileira, e como nota de corte geral o total de 11 pontos, acima do qual se pode dizer que há presença de depressão.

\section{TESTE DE APERCEPÇÃO PARA IDOSOS (SAT)}

O SAT, já empregado em estudos anteriores (GIL, 2005), foi criado em 1949, por Leopold Bellak e Sonya S. Bellak, como uma modificação da Técnica de Apercepção Temática (TAT), no qual são apresentadas 16 pranchas que oferecem como tema questões 
relacionadas ao envelhecimento. Segundo Bellak (1949/1992), o contato com uma técnica projetiva permite uma interação dinâmica entre os objetos do mundo externo e o mundo interno da pessoa, criando-se uma terceira realidade, e a essa percepção denomina-se de apercepção. Quando um estímulo é apresentado a um sujeito, suas respostas, sob a forma de histórias, palavras e comportamentos, são examinadas quanto ao que possam revelar a respeito daquela pessoa.

O SAT é uma técnica projetiva utilizada para investigação da personalidade, em que os estímulos das pranchas foram considerados para detectar possíveis problemas psicológicos. Em sua concepção, Sonya Bellak desenhou 44 pranchas que foram apresentadas aos idosos e, a partir de suas reações, foi feita uma seleção que compõe a configuração atual de 16 pranchas. As gravuras foram desenhadas em tamanho maior se comparadas com as do CAT ou TAT, devido à frequente dificuldade visual dos idosos. A interpretação do SAT pode ser feita por meio da mesma técnica descrita para o CAT e o TAT.

De modo geral, a história de vida e os dados fornecidos no contato com os estímulos do SAT podem propiciar a compreensão da estrutura e da dinâmica da personalidade, além do fato de que o instrumento pode ser utilizado, além do contexto diagnóstico, em uma perspectiva de intervenção terapêutica. Segundo os autores, o objetivo do SAT não é diagnosticar quadros psicopatológicos, mas sim buscar analisar as formas específicas que determinados estados assumem ou pelo que podem causar em um indivíduo em particular. É percebido, então, que frequentemente as histórias refletem problemas que o paciente não pode verbalizar de maneira direta (BELLAK, 1949/1992).

Bellak (1949/1992) afirma ainda que, embora no SAT constem 16 pranchas, não há necessidade de se aplicar todas elas, especialmente se o sujeito tende a ficar fatigado ou a ter um baixo limiar de atenção. Pode-se, nesses casos, escolher as gravuras que, em um julgamento com base nos dados clínicos, são mais propensas a esclarecer os problemas relacionados a elas.

Assim, a escolha das pranchas foi norteada pela ideia de oferecer estímulos que privilegiassem aspectos de relacionamento e sociabilidade, e que permitam um estudo, o mais amplo possível, da personalidade, rejeitando então as pranchas que oferecem estímulos mais explícitos relacionados a aspectos mais patológicos (doença, isolamento, doenças, morte, etc). As pranchas foram apresentadas na ordem $(1,3,4,5,13,14,15$ e 16 - descritas no anexo D) e entregues aos participantes com o pedido para que olhem a figura e imaginem uma história sobre ela. Para a prancha 16, a instrução foi diferente "Eis aqui a gravura de uma pessoa 
tendo um sonho. Conte-me o que pode ser este sonho”. Quando necessário se recomenda um inquérito a partir das histórias apresentadas.

O SAT é também um instrumento pouco pesquisado em nosso país. Destacamos sua utilização com o objetivo de auxiliar o diagnóstico compreensivo de idosos com depressão. Realizamos um estudo que concluiu que, de forma semelhante aos dados da literatura, a análise dos conteúdos das pranchas revelou a tendência ao raciocínio concreto, com presença de autorreferências e mecanismos de defesa pouco elaborados (fuga, idealização, negação e isolamento). Os temas eliciados pelos pacientes corresponderam a temas típicos relatados com respeito às gravuras: necessidade de afiliação, aspectos de dependência, conflitos no relacionamento familiar e limitações impostas pela velhice. (GIL; OLIVEIRA; TARDIVO, 2003).

Empregamos o Teste de Apercepção Temática para idosos (GIL, 2005) não só como auxiliar no psicodiagnóstico de idosos com depressão, mas fundamentalmente como facilitador e mediador no contato terapêutico. Com relação aos aspectos psicodiagnósticos foram também observados alguns dos conteúdos já relatados em trabalhos anteriores e que dizem respeito à presença de raciocínio concreto e presença constante de autorreferências e mecanismo de identificação projetiva. Mais do que utilizado de forma patológica, demonstrou forte necessidade do paciente ser escutado, expressando diretamente seus conflitos e ansiedades, muito mais devido a uma real premência do que como expressão de um mecanismo de defesa frente à situação ansiógena.

Tardivo (2008, 2009, 2010), como citamos anteriormente, ao apresentar resultados de um projeto de pesquisa de validação do SAT, analisa aspectos psicodinâmicos em idosos da cidade de São Paulo com e sem depressão. São considerados resultados obtidos a partir da pesquisa com 102 idosos, na faixa etária entre 60 e 99 anos, divididos em 47 participantes do grupo controle, sem depressão, e 55 do grupo experimental, idosos com queixa de depressão; analisados conforme o referencial de Tardivo (1998) por três juízes. Por meio da análise do SAT, observou-se elevada correlação entre os três juízes que participaram da pesquisa. Constatou-se entre os depressivos mais insegurança e maior grau de sofrimento e ansiedade. Nos dois grupos há: ausência de tendências hostis e agressivas, e necessidade de falar de suas experiências, com muitas histórias na primeira pessoa. 


\section{3 - A Oficina Psicoterapêutica de Cartas, Fotografias e Lembranças}

Os idosos participaram de 16 sessões, com frequência semanal, da Oficina Psicoterapêutica de Cartas, Fotografias e Lembranças. No capítulo referente à introdução teórica, já discorremos sobre esse modo de intervenção psicanalítica. Cada sessão teve a duração de uma hora e trinta minutos, e foi realizada em sala devidamente adequada para o trabalho com grupo. Os materiais utilizados foram: quadro magnético e ímãs para fixação. Após cada sessão o quadro magnético contendo o material trazido pelos participantes foi fotografado pela pesquisadora e essas fotografias compuseram um albúm que ficou disponível aos participantes durante as sessões. A escolha desse tipo de enquadre, no presente estudo, seguiu os parâmetros de um enquadre breve, principalmente quanto ao número de sessões e à adequação dessa forma de processo dirigida a idosos (GAVIÃO, 1996; ALTMAN et al, 2008).

\section{3 - Entrevista Final}

Após o período de duração da Oficina, foi realizada uma entrevista final com cada participante. Na ocasião, foram reaplicados o WHOQOL-BREF - Inventário de Qualidade de Vida da Organização Mundial da Saúde - Forma Breve e o Inventário Beck de Depressão. Os

participantes também fizeram uma avaliação do processo que vivenciaram e foram analisadas as necessidades de encaminhamento para continuidade do atendimento psicológico. 


\section{3- Enquadre e Aspectos Éticos}

A pesquisa foi aprovada pelo Comitê de Ética em Pesquisa com Seres Humanos, do Instituto de Psicologia da USP, de acordo com o Ofício 001/2010 CEPH (Anexo B). Foi estabelecido que o atendimento fosse realizado em 16 sessões, com frequência semanal, com duração de uma hora e meia, nas dependências do local onde funciona o Grupo da Terceira Idade. Os atendimentos foram realizados pela própria pesquisadora. 


\section{CAPÍTULO IV - CONHECENDO OS PARTICIPANTES E O PROCESSO}

Neste capítulo apresentamos, inicialmente, os participantes da pesquisa, considerando os dados das entrevistas iniciais que compreendem os temas contados pelas participantes sobre suas histórias de vida; o resultado das primeiras aplicações da escala de Qualidade de Vida - WHOQOL- BREEF, a Escala Beck de Depressão- BDI, bem como as histórias analisadas a partir do SAT (Anexo E). Com essas informações, realizamos uma síntese da comprensão clínica referente a cada participante.

No segundo momento, abordamos o processo referente ao método psicoterapêutico empregado, e apresentamos os resumos das 16 sessões da Oficina de Cartas, Fotofrafias e Lembranças, identificados por títulos e com as respectivas fotografias.

\section{1 - Apresentação ${ }^{10}$ dos Participantes}

\section{1 - ANGÉLICA}

Angélica é uma senhora de 76 anos, de aparência frágil e que caminha com dificuldade, em razão de artrose nos dois joelhos, amparada por uma bengala. As costas estão encurvadas e a pele, curtida pelos anos de exposição ao ar livre. Sempre trabalhou na lavoura. Ela conta sobre sua tristeza e sobre quanto precisa de ajuda, pois, desde que ficou viúva, sua vida perdeu a graça. Ela chora bastante durante a nossa conversa. Diz que já sofrera muito na vida e que sempre havia conseguido se recuperar, mas o marido lhe fazia muita falta. Ele, alguns anos mais velho do que ela, estivera adoecido por cerca de três anos, com câncer, e faleceu há um ano. Angélica, segundo seu relato, cuidou dele praticamente sozinha. Os filhos e noras não podiam oferecer-lhe o auxílio de que necessitava, pois a maioria, embora morasse na mesma cidade, trabalhava muito; além disso, alguns moravam na zona rural, o que dificultava o acesso à cidade.

Na mesma época em que o marido faleceu, um dos filhos se separou da esposa e veio morar com ela. Apesar de reconhecer que é bom ter companhia, esse é um filho que muito a preocupa, pois ele tem o hábito de, praticamente todos os dias, após sair do trabalho, parar em

\footnotetext{
${ }^{10}$ A fim de preservar a identidade dos participantes todos os nomes são fictícios.
} 
um bar das imediações para beber e voltar para casa, muitas vezes, alcoolizado. $O$ filho recusa qualquer ajuda para se tratar. Angélica conta que, apesar de preocupar-se muito, ele não é agressivo e, ao chegar a casa, vai dormir. Diz que, muitas vezes, se sente sozinha e gostaria de ter alguém para conversar. Antes de o marido ficar doente, eles participavam de algumas atividades do Grupo da Terceira Idade, mas, ultimamente, ela tem se sentido desanimada para frequentá-las, embora procure, mesmo com dificuldades para caminhar, estar presente às reuniões semanais.

Angélica conta também que foi mãe de seis filhos. Somente a caçula era menina - o desejo maior do marido desde a vinda do primeiro filho homem. Há 15 anos, a filha e o genro estavam a caminho de São Paulo, onde houve um acidente, e sua filha faleceu. Ela acha que o genro havia bebido antes de dirigir, pois ele tinha esse hábito. Sofreu muito na época, mas dedicou-se a cuidar da neta, filha única do casal, então com 7 anos. Alguns anos depois, o genro casou-se novamente com uma mulher que, com ciúmes da vida pregressa do marido, dificultava o contato dos avós com a neta. O tempo passou e a neta, agora com 22 anos, já trabalha e, mais independente, procura a avó com frequência, tornando-se a fonte de alegria da vida de Angélica.

Atualmente tem muitos netos e bisnetos, mas se ressente de que nem todos a visitem mais vezes. Além disso, há também o sofrimento de um filho que está com câncer e mora na zona rural, em um lugar de complicado acesso. Isso torna difícil a Angélica visitá-lo, principalmente por ter a locomoção restrita. Ela conta que, apesar da tristeza, também é uma pessoa muito brava, "que não leva desaforos para casa". Sente-se muito aborrecida com o pastor de uma igreja que foi construída, recentemente, ao lado de sua casa. Segundo ela, os frequentadores da igreja fazem muito barulho, falando alto e cantando, em muitas ocasiões, até tarde da noite, o que a incomoda. Ela já reclamou inúmeras vezes e acabou discutindo com o pastor.

A artrose lhe causa muitas dores e "não acha certo sua vida ser só médicos, exames e trabalho da casa”. Diz já ter feito vários tratamentos que não adiantaram muito. Atualmente, os médicos investigam se há algum problema no coração, por isso ela está fazendo vários exames; mas acredita que seu único problema de saúde é mesmo a artrose.

Angélica quer participar do grupo, pois considera que precisa melhorar da tristeza que sente desde a morte do marido. Embora more longe e tenha dificuldades para se deslocar, ela acredita que conseguirá vir aos nossos encontros. Ao final da entrevista, bastante constrangida, diz que gostou muito de conversar, mas tem dúvida se poderá integrar o grupo pelo fato de não saber ler e escrever, pois não teve oportunidade de aprender, ainda que queira 
muito. Eu a tranquilizo dizendo que sua participação será muito bem-vinda, e que não precisa ser alfabetizada para participar da Oficina.

\section{Resultado das escalas:}

BDI: 21 pontos - Depressão moderada

WHOQUOL-BREF: ${ }^{11}$

Domínio Físico: 42.86 / Domínio Psicológico: 37.50 / Domínio Relações Sociais: 33.33 / Domínio Meio Ambiente: 28.13

\section{COMPREENSÃO CLÍNICA}

$\mathrm{Na}$ entrevista inicial, Angélica conta a sua história com uma carga de muita dor e sofrimento. De início, fica evidente grande fragilidade emocional frente a tantos acontecimentos difíceis em sua vida, expressos também em seu corpo curvado e no caminhar com dificuldade. Dentre todos os fatos, a dor pela morte do marido parece ter um lugar central, e ela ressalta que essa é a sua maior razão de sofrimento hoje em dia. As respostas ao WHOQOL-BREF indicaram qualidade de vida abaixo da média em todos os domínios, inclusive no psicológico. O prejuízo na qualidade de vida, vinculado às relações sociais e ao ambiente, pode ser também evidenciado na fala de Angélica, quando ela conta sobre a solidão que sente, as dificuldades em frequentar o grupo da terceira idade e mesmo sobre exclusão social devido ao analfabetismo.

Os resultados da Escala Beck apontam também para os sintomas de depressão: tristeza e desânimo com relação ao futuro; sensação de fracasso e decepção consigo mesma. Essa escala favoreceu a expressão dos sentimentos de Angélica e ela demonstra, ao dar as respostas, sentimentos de culpa relacionados às suas perdas no passado, pois acredita que poderia ter orientado melhor a filha assim como ter cuidado mais do marido doente.

A expressão da culpa que sente também está presente quando conta sobre filho doente que ela não consegue ajudar em função de suas próprias limitações fisicas; e sobre o outro filho que recusa ajuda para lidar com os problemas relacionados ao álcool. Durante o relato de Angélica, ao lado da culpa surgem também sentimentos de rejeição e menos valia que

${ }^{11}$ Conforme os critérios estatísticos relativos à avaliação da escala, os resultados do WHOQOL-BREF são expressos em percentis e não em números brutos, pois é forma considerada mais adequada para comparar os dados dos retestes entre os participantes. 
contribuem para um estado de grande fragilidade emocional. Frente aos estímulos oferecidos pelo SAT, Angélica projeta nas cinco primeiras histórias conteúdos relacionados a doenças e à necessidade de tratamento e cura.

As gravuras, segundo Bellak (1949/1992), facilitam o surgimento de referências a relações sociais e familiares que nos permitem perceber justamente os conteúdos relacionados à fragilidade e insegurança, assim como os de necessidade e esperança por ajuda. Compreendemos também que, na relação transferencial que se estabelece, ela demonstra acreditar no apoio que pode receber por meio do trabalho proposto.

A história que Angélica conta na gravura 15 diz respeito a sua própria vivência. Ela traz o sofrimento pela perda do marido. De modo semelhante ao que encontramos em pesquisas anteriores (GIL, 2005; TARDIVO, 2009), as histórias autorreferentes são notadas com frequência em pacientes depressivos e, em especial, nos idosos, denotando não necessariamente um aspecto patológico, mas sim, como é o caso de Angélica, grande necessidade de ser escutada, colocando diretamente os seus conflitos e ansiedades.

Devemos considerar também que, ao lado da fragilidade emocional e dos sintomas depressivos, expressos na entrevista inicial e por meio dos instrumentos utilizados, Angélica, ao final do nosso primeiro contato, revela também tendências mais construtivas, o que a leva a se colocar de modo mais ativo na vida: ela briga pelos seus direitos, não quer se limitar frente às dificuldades de sua vida (quanto à locomoção e o analfabetismo, por exemplo).

Podemos relacionar esse fato ao melhor resultado no WHOQOL com relação ao domínio físico - embora também esteja ligeiramente abaixo da média -, se comparado aos demais. Assim, um resultado que contrastava inicialmente com a aparência fragil de Angélica, e com um relato de dores devido à artrose, pode ser entendido, não obstante seu estado mais depressivo, no contexto de tendências mais construtivas que ela apresenta. O prejuízo em sua qualidade de vida não se mostra determinado de forma preponderante pelas condições físicas, mas está muito mais relacionado aos fatores sociais e ambientais. Essas tendências, embora não sejam predominantes, são também projetadas nas pranchas 13 e 16 do SAT, quando ela parece se sentir mais segura para poder expressar, ainda de maneira bastante tímida, seus desejos, como andar de avião, e fantasias, como sonhar com a família e namorar. 


\section{2 - BENTO}

Bento, 65 anos, é o único participante do sexo masculino no grupo e o mais novo também. Chama a atenção pelo modo como chega: dirigindo um tipo de bicicleta motorizada. Acomoda o capacete em uma cadeira e diz que fora difícil tomar a decisão de procurar à psicóloga; que sempre teve curiosidade, mas muito receio também. De gestos calmos e fala pausada, Bento que, inicialmente, parecia bastante tímido, aos poucos vai parecendo estar mais a vontade. Conta que é casado, tem três filhos ainda solteiros que moram com ele, e muito orgulho de ter conseguido que todos se formassem na faculdade.

Oriundo de uma família bastante simples, concluiu, com muita dificuldade, o ensino médio. Há muito tempo tem uma pequena oficina onde conserta diversos tipos de aparelhos elétricos. Ao falar sobre seu trabalho, ele explica que a bicicleta motorizada que possui, tem o objetivo de agilizar o atendimento, que muitas vezes é em domicílio. Apesar de gostar bastante do que faz, ultimamente tem diminuído o ritmo de trabalho, pois se sente bastante cansado.

Alguns anos atrás, descobriu que tem problemas cardíacos e preocupa-se bastante com isso. Ele sentia taquicardia e falta de ar, mesmo em atividades que não requeriam muito esforço. No momento sente-se bem, mas já fez uma angioplastia. Atualmente, faz exames, pois existe possibilidade de se submeter a uma nova cirurgia, em breve. Receia que isso venha a acontecer, pois tem medo da cirurgia e suas consequências; não quer parar de trabalhar nem se sentir um inativo e dependente de todos. Ele conta que, ao pensar nisso, lembra-se de seu pai, já falecido, que também sofria do coração e, após ter um enfarte, passou a levar uma vida com muitas limitações. Bento tem medo do mesmo destino, e isso o deixa, às vezes, muito triste e desanimado.

Os filhos insistem para ele procurar um psicólogo, pois o acham muito calado - não se abre com eles nem com a esposa. Bento pensa que o fato de ser fechado incomoda bastante a família, e a esposa lhe diz com frequência que, guardar tanto as coisas assim, pode fazer mal. Ele conta que o relacionamento com a esposa é bom, eles se casaram cedo, ambos com 22 anos, e sempre viveram bem, mas se sente constrangido quando ela o critica por seu jeito reservado de ser. Passou a frequentar o Grupo da Terceira Idade, por insistência da esposa, acompanhando-a, principalmente, nas atividades recreativas e nos passeios. Se de início sentia-se um pouco forçado a participar, hoje gosta bastante. 
Ao final da entrevista, Bento diz que outra preocupação que enfrenta diz respeito às dificuldades na área sexual. Os problemas do coração o deixam bastante inseguro e, muitas vezes, não consegue se relacionar sexualmente com a esposa. Ao mesmo tempo, tem medo de tomar remédio para aumentar a potência sexual e fazer mal para o coração. Acha que um trabalho em grupo poderá ajudá-lo, principalmente ao ver que outras pessoas também têm problemas como os dele, e que não é o único a sofrer em momentos da vida. Bento fala ainda que não deseja que sua família saiba de sua participação no grupo. Pensa que é algo só dele, quer sentir primeiro suas impressões para depois contar e, além disso, tem receio de criar expectativas na família quanto a mudanças em seu comportamento.

\section{Resultado das Escalas:}

BDI: 11 pontos - Depressão leve

WHOQOL- BREEF:

Domínio Físico: 67.86 / Domínio psicológico: 54.17 / Domínio Relações Sociais: 33.33/ Domínio Meio Ambiente: 53.13

\section{COMPREENSÃO CLÍNICA}

No início de nosso primeiro contato, Bento, de fato, mostrou-se bastante reservado. Porém, aos poucos, pude perceber que, ao se sentir mais confiante, pôde expressar, ao longo da entrevista, o medo e a angústia que sentia frente à doença cardíaca e a perspectiva de ter que enfrentar uma cirurgia, em breve. As respostas à Escala Beck refletiram, em parte, estes sentimentos: insegurança, muitas vezes tristeza, e falta do prazer nas coisas como sentia anteriormente, indicando um quadro de depressão leve. Ainda com relação à Escala Beck de depressão, é importante destacar que, ao se identificar com a questão que afirmava seu modo de ser crítico com relação a si mesmo, devido a fraquezas e erros, Bento traz um grande sentimento de culpa. Reforçado pelo discurso sobre a família, sente-se responsável pelo sofrimento da esposa e dos filhos, pois acredita no fato de que sua doença está relacionada ao seu modo muito fechado de ser e à dificuldade em demonstrar seus sentimentos.

A aplicação do WHOQOL-BREF evidenciou uma qualidade de vida considerada praticamente na média com relação ao domínio psicológico, e superior à média com relação 
ao físico; o domínio que se mostrou mais comprometido é o que diz respeito às relações sociais. Podemos compreender esses dados quando pensamos que a dificuldade que Bento relata de expor seus sentimentos e o fato de ser muito reservado geram prejuízos no campo das relações sociais e pessoais. Com relação ao domínio físico, embora estivesse preocupado com a saúde e o risco da cirurgia, conforme o relato, ele se sentia bem fisicamente. Podemos atribuir também o resultado acima da média com relação ao domínio psicológico, à estruturação de suas defesas, o que se evidenciou também na aplicação da técnica projetiva SAT.

Suas respostas ao SAT, de início, parecem refletir esses conteúdos mais depressivos. Ele conta uma história referente à gravura 1 que, segundo Bellak (1949/1992), é considerada mais "inócua", facilitando o surgimento de referências a relações sociais. Nela, o personagem com o qual ele parece se identificar está em uma situação em que, ao ser pressionado, sente-se desprotegido e deprimido. Além do mais, do mesmo modo que verbalizara durante a aplicação do BDI, atribui a si a responsabilidade de ter feito "algo errado", tal qual o personagem da história, e que não é aceito por quem está a sua volta, refletindo assim o sentimento de culpa que já havia surgido anteriormente.

$\mathrm{Na}$ sequência, a história referente à prancha 3 fala de um personagem que está em "um lugar que não pode sair sozinho", mas que pode receber ajuda para sair de uma situação difícil. Acreditamos que esse momento trata-se de uma projeção associada ao campo transferencial que se estabelece durante as entrevistas, quando Bento apresenta demanda por cuidado e esperança de poder conseguir o apoio de que necessita no processo psicoterapêutico.

Nas gravuras seguintes, Bento parece estruturar melhor seus mecanismos de defesa e apresenta histórias mais descritivas, com projeções menos intensas, consequência de maior repressão dos seus sentimentos. No entanto, na prancha 15, segundo Bellak (1949/1992), pôde expressar, entre outros, temas relacionados a relações entre gerações em um nível social e sexual. Bento traz uma história em que, no primeiro momento, um casal está "se paquerando" e, em seguida, o interesse passa a ser somente do homem e não da mulher, quando diz que "ele que está a fim dela, ela não está". Na história a relação se estabelece com um casal da mesma geração, o que reforça a ideia de que Bento, a partir da projeção frente aos estímulos daquela gravura, fala de sua preocupação quanto às dificuldades enfrentadas na área sexual e à fantasia, relativa ao temor que esse problema resulte em possível rejeição de sua esposa. 
Após os dois primeiros encontros, percebemos que Bento mostrou-se bastante motivado a participar do grupo e que, não obstante os sentimentos de angústia e insegurança presentes, principalmente com relação à situação concreta que enfrentava, dada à eminência da cirurgia cardiaca, demonstrava confiança em sua decisão de buscar o cuidado necessário no campo emocional.

\section{3 - CLARA}

Clara é uma senhora de 79 anos; com uma aparência mais jovial, aparenta ter menos idade. É uma pessoa risonha e bastante agitada. Diz que gosta de participar de todas as atividades do Grupo da Terceira Idade e que é frequentadora assídua das atividades de ginástica, bem como dos vários cursos oferecidos pelo grupo. Nunca participou de trabalho com psicólogos e tem muita curiosidade para saber como é. Acha que, embora não tenha maiores problemas para resolver, vai aproveitar o que pode aprender com a psicóloga e com o grupo, o que, segundo ela, "só pode ser algo que faz bem as pessoas".

Clara tem uma única filha, que por sua vez lhe deu quatro netos. Ela mora com esta filha e o genro e conta que tem um bom convívio com todos. $\mathrm{O}$ fato de conviver com os netos, alguns ainda adolescentes, segunda ela, gera por vezes alguns conflitos, pois se preocupa com a segurança deles e às vezes tem opiniões diferentes da dos pais quanto à educação de filhos.

Porém, ressalta, não enxerga o convívio como um problema, não se importando também quando a filha, genros e netos opinam sobre a sua vida, o que segundo ela, ocorre com frequência.

Clara, criada na lavoura, ajudando os pais em uma cidade do interior de São Paulo, também foi filha única. Quando jovem, os pais não aceitaram o envolvimento com um namorado e ela acabou saindo de casa, indo morar, aos 15 anos, em outra cidade, com uma tia, irmã de sua mãe. Segundo ela, os pais eram muito rigorosos, não permitiam a ela namorar e frequentar festas, o que gerava muitos conflitos na família. À medida que os conflitos iam ficando mais intensos, Clara insistia para morar com a tia. Segundo ela, além de se afastar do convívio dos pais, poderia voltar a estudar, pois o fato de morar em um sítio, na zona rural, a impedia de dar continuidade aos estudos. 
Segundo ela, a relação com a tia e primos era boa, mas por dificuldades financeiras, ela acabou se empregando como doméstica na casa de uma família da região. Lá, conheceu o marido que trabalhava como caseiro na chácara da família, e se casaram. Ele era cerca de oito anos mais velho e, com o seu incentivo, Clara voltou a estudar até completar o ensino médio.

Há dez anos, o marido faleceu devido a problemas cardíacos. Diz ter sido muito difícil ficar sem ele, pois tinham um relacionamento muito bom. Ele era mais velho e cuidava dela com muito carinho. Ela acredita que superou esse momento difícil graças ao seu jeito otimista de encarar a vida. Hoje se sente bem adaptada, tem saudade do marido, mas não encara a viuvez como um problema. É bastante ativa e gosta muito de aprender coisas novas. Durante os nossos encontros individuais, embora eu houvesse explicado a Clara sobre o processo psicoterapêutico e a função do psicólogo, ela insistia, de modo animado e efusivo, em chamar as sessões de "aulas" e ressaltava, diversas vezes, o quanto esperava "aprender" comigo e com os demais participantes do grupo.

\section{Resultado das Escalas:}

BDI: 3 -Ausência de depressão

WHOQUOL-BREF:

Domínio Físico: 60.71 / Domínio Psicológico: 62.50 / Domínio Relações Sociais: 66.67 / Domínio Meio ambiente: 68.75 


\section{COMPREENSÃO CLÍNICA}

Clara se apresentou, de início, bastante animada a participar do grupo. Em uma conversa posterior com a assistente social que conduzia as atividades do Grupo da Terceira Idade, ela ressaltou o quanto Clara é participativa, presente na maioria das atividades que coordena. Com relação às respostas dadas aos inventários, de modo geral, ressaltaram os conteúdos mais positivos e saudáveis. A Escala WHOQOL-BREF refletiu qualidade de vida acima da média em todos os domínios, e no BDI a única pontuação foi relativa às questões relacionadas a características do processo natural de envelhecimento

No entanto, no decorrer da conversa com Clara, embora ela se mostrasse bastante falante, fui percebendo dificuldades em expressar sentimentos frente a situações da vida atual. Quando eu perguntava algo do presente, ela parecia ficar tensa e não se aprofundava, recorrendo a histórias de seu passado. Assim, ao mesmo tempo em que se mostrou interessada no trabalho a ser desenvolvido, notei uma atitude na qual ela, de maneira defensiva, parecia negar algumas questões de sua vida, ou ainda ter dificuldades para entrar em contato com elas. Esse fato pode ser evidenciado em sua fala, quando afirmava não ter "maiores problemas" para resolver, ou quando diz que os temas referentes ao convívio com a família não representam questões conflitantes para ela, ou seja, as situações em que ela relatava pontos de possíveis conflitos em sua vida, mas que na fala seguinte eram amenizados ou mesmo negados.

A partir das histórias que Clara contou durante a aplicação do SAT, essa hipótese pareceu se confirmar, pois frente aos estímulos oferecidos pelas gravuras, foram projetadas situações de conflitos, em sua maioria possivelmente inconscientes, que, do nosso ponto de vista, podem corresponder a questões relativas à sua vida, tanto presente quanto passada. As histórias do SAT são diferentes dos dados da entrevista e dos inventários, pois tanto a Escala de qualidade de vida (WHOQOL-BREF) quanto a Escala de depressão (BDI) medem aspectos distintos dos analisados no SAT. Podemos, então, considerar que as escalas tratam de comportamentos manifestos, enquanto o SAT é um instrumento projetivo que analisa conteúdos mais profundos da personalidade. Assim, Clara, tanto na entrevista inicial quanto nas respostas às escalas, se apresenta de forma mais defensiva, enquanto no SAT ela demonstra os conflitos relacionados, por exemplo, ao lugar que ocupa na família e as fantasias relativas a essa situação, como podemos observar nas histórias referentes às gravuras 1 e 13 . 
Na gravura 1, a personagem principal, por um lado, deseja ir embora da casa de seus familiares para poder se sentir mais livre e independente e, por outro, demonstra o receio da solidão e o temor de desagradar à família com tal atitude. Não podemos também deixar de notar a repetição, na história de vivências de seu passado, quando ela provavelmente apresentou os mesmos conflitos ao sair da casa dos pais para morar com a tia. É importante observar que, na sequência, frente à cena da gravura 3 que, segundo Bellack (1949/ 1992), pode estimular projeções de sentimentos de hostilidade e rivalidade entre os personagens, Clara parece expressar conteúdos mais regredidos, possivelmente se identificando com a criança insatisfeita, que, ao ser a única filha - como é o caso dela própria e também de sua filha -, é alvo da competição dos pais.

A temática expressa na gravura 1 aparece de modo semelhante na gravura 13, que, segundo Bellak (1949/1992), sugere muitas vezes conteúdos verbalizados em histórias relativas a viagens, visitas a filhos, abandono, retorno; e ansiedade com respeito ao futuro e ao destino. Clara cria naquela gravura uma história que expressa, ainda de modo mais claro, sua preocupação com o seu lugar na família, tanto no presente quanto no futuro, trazendo sentimentos de insegurança, medo da solidão e receio de, ao necessitar de cuidados, representar uma carga pesada demais para a família.

Ainda a partir das gravuras 4 e 15, Clara projeta seus conflitos familiares em personagens que ora recriminam a atitude da mãe - que na história esquece-se do seu filho priorizando o telefonema; ora precisam se preocupar com os netos mais que os pais, e têm de lidar tanto com os perigos a que estes estão expostos quanto com a reprovação dos netos, frente a um comportamento mais protetor por parte dos avós.

De modo geral, devemos considerar que, embora Clara tenha demonstrado, durante as entrevistas, dificuldades em entrar em contato com os sentimentos gerados por possíveis conflitos que vivencia, estes puderam ser expressos por meio das associações, a partir dos estímulos favorecidos pelas gravuras do SAT. Podemos pensar que a necessidade de instrumentalizar sua defesa, frente à insegurança e à angústia que sente, levou Clara a uma vivência, embora não patológica, de certa dissociação; isso a fez negar, em suas verbalizações, no primeiro momento, sua verdadeira demanda pelo auxílio da psicoterapia, substituindo-a, assim, pela ideia da psicoterapia como um "curso" onde ela poderia adquir conhecimento e, desse modo, frequentar sessões fantasiadas como "aulas". No entanto, destacamos o fato de que, mesmo apresentando essa dinâmica mais defensiva, Clara aceitou o 
convite para participar da Oficina, o que nos levou a reforçar a oferta de um ambiente que, ao favoreçer o holding necessário (WINNICOTT, 1962/1983), permitisse o seu desenvolvimento e elaborações em um tempo próprio.

\section{4 - TEREZA}

Tereza tem 71 anos e é muito agitada. Fala bastante e queixa-se de muitas coisas. Disse sofrer do coração, ser hipertensa, ter diabete e depressão. Segundo ela, vai tanto ao Posto de Saúde da cidade que já é conhecida por todos os médicos. Conta que, na juventude e mesmo antes de ficar doente, era uma pessoa muito alegre e festeira, sempre buscando reunir a família e os amigos a sua volta. Hoje em dia, apesar de gostar muito das atividades do Grupo da Terceira Idade, quase não as tem frequentado em razão dos problemas de saúde e do desânimo que sente. No entanto, mesmo procurando se tratar, tem muito medo de morrer ou de ficar inválida com essas doenças.

Segundo ela, os médicos atribuem os sintomas depressivos que apresenta, em parte, ao problema cardíaco e ao diabétes, e principalmente à sua ansiedade e ao nervosismo; recomendaram a ela que procurasse um psicólogo para tratar também desses sintomas. Ela chegou a procurar a psicóloga no Posto de Saúde para um tratamento individual, mas disse preferir o atendimento em grupo, pois acredita que ouvir os problemas de outras pessoas pode ajudá-la.

Tereza veio da Bahia para o interior de São Paulo com 21 anos; aqui conheceu o marido e criou os filhos e netos. Ainda tem parentes na Bahia, principalmente irmãos, dos quais sente muita saudade. Em todos esses anos, ela pôde voltar a sua cidade natal somente duas vezes. Além de a viagem ser cara, diz ela, foi difícil surgir oportunidade para isso, pois esteve sempre trabalhando e cuidando da família. Hoje aposentados, seu marido trabalhava no ramo da construção civil e ela era costureira em uma tecelagem. Tereza conta que sempre foi muito trabalhadora e que hoje sente falta de outras atividades, além de cuidar da casa e dos netos, e atribui à ausência de uma vida mais ativa os seus problemas de saúde.

Segundo Tereza, há um bom relacionamento com o marido, que é muito calmo e tranquilo. No entanto, o comportamento dela é oposto, pois conta que briga muito com todos 
a sua volta, principalmente com os inquilinos de uma casa no mesmo quintal, pois se comportam de forma que ela não gosta, fazendo barulho e falando muitos palavrões. Ela tem três filhos já casados e sete netos; todos moram próximos a ela. Tereza diz que, embora se dedique muito à família, e está sempre procurando ajudà-los como pode, vive muito nervosa e preocupada com todos, principalmente filhos e netos, o que, no seu modo de ver, só agrava seus problemas de saúde.

Atualmente seu maior problema é com um dos netos, rapaz de 18 anos que não gosta de estudar e anda em más companhias. Recentemente foi surpreendido pela polícia pichando os muros da cidade. O pai dele precisou ir à delegacia para colocá-lo em liberdade, mas ele foi condenado a prestar trabalhos comunitários. Tem muito medo da violência e teme que os netos se desviem para a marginalidade; pensa nisso o tempo todo. Ela leva essas preocupações para os filhos e acha que eles, mesmo adultos, precisam de sua orientação, pois os julga, muitas vezes, permissivos na educação dos netos. Os filhos a acusam de ser muito controladora e, com frequência, há brigas e conflitos, tanto com eles quanto com os netos.

Ao final de nosso primeiro contato, Tereza conta que, quanto à depressão, já tentou tomar a medicação recomendada pelo psiquiatra, mas interrompeu o tratamento porque acha que o remédio the fez mal. Sente-se desanimada e com pouca energia, mas, segundo ela, a depressão não a impede de fazer suas tarefas diárias. Tereza fala que não tem certeza de que a psicoterapia possa ajudá-la de fato, mas quer tentar um tratamento psicológico para ser "uma pessoa diferente". Foi-lhe recomendado, ao final da entrevista, que, além de participar da Oficina, voltasse a procurar o psiquiatra para reavaliar o tratamento medicamentoso para a depressão.

\section{Resultado das Escalas:}

BDI: 31 -Depressão severa

WHOQOL-BREF:

Domínio Físico: 35.71 / Domínio Psicológico: 45.83 / Domínio Relações Sociais: 58.33 / Domínio Meio Ambiente: 43.75 


\section{COMPREENSÃO CLÍNICA}

O contato inicial com Tereza deixou a impressão de uma pessoa muito ansiosa e agitada, que durante a entrevista falou praticamente sem pausas, emendando um assunto ao outro. A aplicação da Escala Beck evidenciou os sintomas depressivos e, devido à pontuação alta, indicou um quadro de depressão considerada severa. De acordo com o BDI, ela se identificou com as afirmações que indicavam principalmente tristeza, falta de esperança, insatisfação e irritabilidade constante. Além disso, relatou sintomas físicos como falta de energia e alterações no sono, na concentração e no apetite.

Quanto à qualidade de vida, de acordo com o WHOQOL-BREF, o comprometimento maior está no domínio físico, resultado que corresponde à fala de Tereza, ao se queixar de muitas doenças e visitar sucessivamente médicos. O resultado referente ao domínio psicológico, embora abaixo da média, parece não corresponder a um quadro de depressão tão severa como indicou o BDI.

O resultado do BDI e as verbalizações de Tereza destacaram a sintomatologia depressiva, mas, no contato com ela, ficou bastante evidente a presença de ansiedade e irritabilidade, sintomas que são considerados também uma forma de expressão característica de quadros depressivos. Esse tipo de sintomas é mais frequente em homens do que em mulheres e, muitas vezes, é associado a alterações físicas relacionadas a doenças cardíacas ${ }^{12}$, como é o caso de Tereza.

A aplicação do método projetivo - SAT trouxe como tema principal relativo às primeiras gravuras (1 e 3), a necessidade de proteção e ajuda, evidenciando, em um primeiro momento, uma atitude básica de insegurança, o que, segundo estudo realizado por Tardivo (2009) e outros autores, é característica de quadros depressivos. Na gravura 1, a necessidade de ser ajudada aparece ligada a sintomas físicos: a personagem tem problemas nas pernas e na coluna. Já na gravura 3, é projetado o medo da morte no personagem que está se afogando.

É interessante notar que, sob outra faceta, podemos pensar na dinâmica projetada nessas gravuras como também advindas da relação transferencial que se estabeleceu durante o

\footnotetext{
${ }^{12}$ Esta afirmativa baseia-se em pesquisas realizadas por nós no Laboratório de Saúde Mental e Psicologia Clínica Social do IPUSP. Consultar em: Gil; Paulo; Tardivo; Tung, 2004.
} 
nosso contato. Assim, podemos pensar no conflito e nas expectativas de Tereza quanto à ajuda que pode receber no processo psicoterapêutico, que são expressos de forma dual: na primeira história a personagem vai ser ajudada, o que não acontece na segunda história, onde os pais do personagem estão muito longe e, não conseguindo salvá-lo, ele morre afogado.

Nessa mesma linha, podemos considerar a resposta à gravura 4 como uma representação de um bom prognóstico quanto à confiança de Tereza de que pode receber ajuda, pois se trata de uma história em que retrata uma idosa que, embora ainda em conflito, tende a aceitar o auxílio - no caso da história, para ser ensinada como pegar o nenê. Por outro lado, segundo Bellak (1949/1992), esta gravura pode estimular projeções quanto a relações conflitivas no âmbito familiar e, assim, Tereza identifica-se com a idosa da história que tende a aceitar a ajuda. Ela também pode ter se identificado com o personagem do pai, que expressa um comportamento semelhante ao verbalizado por ela durante a entrevista na queixa aos filhos, ou seja, a necessidade de controlar as atitudes dos familiares.

Ainda no que diz respeito às relações familiares, a gravura 15 também retrata uma situação onde é enfatizado o modo como os pais, na história, são vistos - figuras de apoio para os filhos -, reforçando a ideia que Tereza externou nas entrevistas, de uma autoimagem centralizadora e responsável pela segurança e o bem-estar da família. Chamou também a nossa atenção, o conteúdo da história referente à gravura 14, que, conforme apontado por Bellak (1949/1992), estimula, com frequência, circunstâncias relacionadas a enfermidades e remédios. Frente a essa gravura, no entanto, Tereza conta uma história na qual suprime essa temática tão frequente entre as respostas de idosos, fazendo referência a um funcionário que conserta a pia da casa.

De todo modo, é importante destacar que, levando em conta o nosso contato nas entrevistas, Tereza deu grande destaque aos sintomas depressivos e nos chama a atenção o estado ansioso no qual se encontra, bem como os impulsos agressivos frente às tentativas de controlar o ambiente que a cerca, evidenciando assim o seu sofrimento psíquico. 


\subsection{ISA}

Isa é uma senhora de 69 anos, muito magra e delicada. De aparência bastante frágil, tão logo começa a falar sobre sua vida, chora. É um choro silencioso, que não chega a embargar sua voz, enquanto me conta sobre seu filho mais velho que, aos 43 anos de idade, faleceu há seis meses, vítima de câncer no estomago. Embora tenha o apoio do marido, do filho mais novo e também das noras e netos, sente-se muito triste o tempo todo, pois segundo ela, não se conforma com a morte do filho. A família, bastante preocupada, insistiu para Isa procurar atendimento psicológico, pois acham que seu processo de luto está muito intenso e sofrido.

Isa nasceu no interior de Minas Gerais e foi criada em uma fazenda que pertencia a sua família. No local, além dela e dos irmãos, moravam em casas vizinhas os avós, tios e primos. Ela fala da infância e juventude como uma época muito feliz, sempre na companhia de uma família grande e alegre. Conheceu o marido na cidade vizinha e, após o casamento, vieram para interior de São Paulo, pois ele conseguira um emprego em uma indústria da região. Disse que a adaptação na cidade foi difícil, pois era muito tímida e mais reservada, além de sentir muita falta da família. Porém, acabou se adaptando e gostando da cidade, onde criou os dois filhos.

Ela conta da grande afinidade que tinha com o filho mais velho, pois o considerava muito parecido com ela. Já o filho mais novo tem características mais parecidas com as do pai. Isa disse que cuidou do filho até o final; que não sente nenhuma culpa, mas não consegue aceitar a sua morte, pois sempre teve um relacionamento muito bom com ele, o que torna ainda mais difícil continuar vivendo tendo que lidar com sua ausência. Sente também muita pena da nora e dos netos pequenos, de 6 e 8 anos, que vão crescer sem a presença do pai.

Professora de piano, desde a morte do filho não consegue mais tocar e precisou dispensar alguns alunos; isso tem prejudicado o orçamento familiar, uma vez vivem da aposentadoria do marido. Sempre gostou muito de participar das atividades do Grupo da Terceira Idade e costumava ir a alguns bailes com o marido aos finais de semana. No entanto, após a morte do filho, parou de frequentar o grupo. Soube da possibilidade de se integrar ao trabalho da Oficina por meio do marido que participa das reuniões semanais do Grupo da Terceita Idade, e pediu a ela que agendasse uma entrevista comigo. Após explicar a Isa como funcionaria o grupo, disse a ela que, embora estivesse mobilizada pela preocupação da família, era importante que ela mesma avaliasse a sua necessidade e vontade de participar do 
processo psicoterapêutico, ao que ela me respondeu: "Eu quero vir sim, porque se a gente não se ajudar os outros também não podem, não é?”

\section{Resultado das Escalas:}

BDI: 13 - Depressão leve

WHOQOL-BREF:

Domínio Físico: 46.43 / Domínio psicológico: 37.50 / Domínio Relações Sociais: 25.00 / Domínio Meio Ambiente: 46.88

\section{COMPREENSÃO CLÍNICA}

Desde o primeiro momento de nosso contato, pudemos perceber que estávamos diante de uma senhora que enfrentava um grande sofrimento emocional. Isa, sem dúvida, vivia um luto muito difícil, o que parecia angustiar os familiares e amigos à sua volta. A aplicação da Escala Beck de depressão indicou um quadro de depressão leve, com características como: tristeza, desânimo, falta de prazer nas coisas e de interesse pelas pessoas, além da dificuldade em tomar decisões, e algumas alterações de sono e apetite.

A sua qualidade de vida mostrou-se comprometida, o que pode ser observado, principalmente, nas respostas ao WHOQOL, que indicaram uma pontuação abaixo da média,

principalmente com relação aos domínios psicológico e relações sociais; os resultados correspondiam à fala de Isa ao contar sobre o seu sofrimento devido à morte do filho. A qualidade de vida de Isa, referente aos domínios citados, demonstrou prejuízos e um quadro mais acentuado do que o indicado no resultado do BDI.

Embora a pontuação obtida apontasse para um quadro de depressão leve, Isa pareceu ter um quadro depressivo mais intenso, pois chorava muito, demonstrando certa passividade em suas atitudes, por exemplo, ao relatar que havia procurado apoio psicoterapêutico por insistência da família. Todas essas questões faziam pensar se o estado melancólico de Isa era consequência de um luto, que ainda não havia sido superado e que poderia se transformar em condição patológica, ou se havia uma estrutura de personalidade mais depressiva, anterior ao 
próprio trauma que havia sofrido. Essa resposta, no entanto, poderia somente ser construída a partir da participação dela no processo psicoterapêutico.

A aplicação do SAT revelou histórias em sua maioria bastante simples e descritivas. A partir das histórias referentes às gravuras 1, 4 e 5, que sugerem temas, segundo Bellak (1949/1992), relacionados ao convívio familiar e social, Isa pareceu, ao entrar em contato com esses estímulos, se defender, possivelmente, do sofrimento gerado pelas lembranças do filho. Desse modo, ela parece negar os estímulos daquelas gravuras, contando histórias curtas e mais descritivas, nas quais não se aprofunda e termina dizendo que não há mais nada para contar sobre elas.

Nessa sequência, há uma exceção quanto à gravura 3, que pode ter representado a necessidade de reparação frente à perda, pois Isa conta a história de pais que conseguem salvar o filho de um afogamento e termina com um final feliz. Nessa mesma linha, a gravura 16, trouxe o desejo de estar no paraíso, o que associamos com a idéia do reencontro com o filho. Assim como, na gravura 3, o final do sonho que a senhora relata na história - como é a instrução para esta gravura - está associado ao bem estar e ao prazer.

$\mathrm{Na}$ gravura 15, Isa, a partir dos estímulos oferecidos, conta uma história autorreferente, na qual se lembra do tempo em que ia aos bailes com o marido e de suas limitações vivenciadas nos dias de hoje. Conforme já referimos, essa forma de expressar diretamente seus conflitos e angústias nas histórias são notadas com frequência em pacientes depressivos e, em especial, nos idosos, e refletem a necessidade pela atenção e escuta, não sendo considerado necessariamente um sinal patológico. (GIL, 2005; TARDIVO, 2009).

Como relatado no final da primeira entrevista, a demanda de Isa em participar da Oficina estava bastante vinculada à necessidade sentida por seus familiares. Como já dissemos em estudos anteriores (GIL, 2005), a depressão no idoso caracteriza-se muitas vezes pela perda da autonomia e por um estado de passividade frente à própria vida. Diante da escolha em participar da Oficina psicoterapêutica como opção dela, notamos que, mesmo enfrentando dificuldades, Isa parecia disposta a buscar ajuda para o seu sofrimento. 


\subsection{LÚCIA}

Lúcia tem 79 anos, é uma senhora de aparência séria e reservada, e aparenta ser mais jovem do que a idade que tem. Logo de início, conta que sua vida podia ser dividida em duas etapas: até os 60 anos, quando era casada e morava em São Paulo, e após essa idade, quando se separou e mudou-se para o interior de São Paulo. Lúcia tem três filhas casadas e três netos, todos residentes em São Paulo. Seu marido era médico e ela, dona de casa. Até a separação viviam, segundo ela, de forma "razoável", pois sentia que, embora não houvesse brigas, o relacionamento era um pouco distante. Conta que o marido era bastante exigente no cuidado com as filhas e a casa. Mesmo tendo completado o ensino médio, não conseguiu cursar uma faculdade, como era seu sonho, e também não pôde trabalhar fora de casa.

Aos 60 anos o marido, hoje já falecido, a abandonou para se casar com uma mulher bem mais jovem, e na época isso foi muito difícil. Impactada por algo que nunca imaginou que acontecesse em sua vida, ficou inicialmente com muita raiva, que mais tarde deu lugar à tristeza. Hoje, passados todos esses anos, sente-se mais recuperada, mas ainda considera que esta é a grande mágoa que tem.

$\mathrm{Na}$ época da separação, embora as filhas já estivessem casadas e o ex-marido continuasse a auxiliá-la financeiramente, seu padrão de vida caíra bastante e ela precisou mudar-se de São Paulo para o interior, onde uma de suas irmãs residia. Essa adaptação foi muito desgastante, pois Lúcia tinha muitos vínculos em São Paulo e valorizava as oportunidades culturais e sociais da cidade. Ao mesmo tempo, ressentia-se das filhas não a incentivarem a permanecer morando em São Paulo, como era seu desejo. Lúcia sente que nunca conseguiu se adaptar totalmente à nova cidade e demonstrou sentimento de perda, e também certo ressentimento, com as circunstâncias da vida que teve que enfrentar.

Lúcia sentiu que a situação começou a melhorar quando iniciou a participação no Grupo da Terceira Idade, pois fez novos amigos e passou a sentir-se menos só. A irmã, que mora na mesma cidade, é casada, tem filhos e netos, e, segundo ela, tem também um jeito de ser diferente do seu, mais caseiro e acomodado, e por isso elas acabam tendo menos convívio. Gostaria que as filhas e netos a visitassem e a levassem para passear em São Paulo com mais frequência e, como isso não acontece, sente-se bastante magoada. 
Ela acha que tem muitas mágoas devido aos fatos difíceis de sua vida, porém reconhece que, o que mais a incomoda hoje em dia, é a solidão e muitas vezes também a sensação de abandono por parte das filhas e netos. Acha que sua saúde de modo geral é boa e que poderia aproveitar melhor a sua vida. Considera que o grupo de psicologia pode ajudá-la a lidar melhor com essas questões, mas reconhece que sua principal motivação é ser atendida por uma psicóloga que venha de São Paulo e também da USP, o que a faz sentir tendo uma oportunidade de crescimento, pois segundo ela, a vida na cidade pequena acaba por não suprir suas reais necessidades.

\section{Resultado das Escalas:}

BDI: 9 - Ausência de depressão

WHOQOL-BREF:

Domínio Físico: 60.71 / Domínio Psicológico: 54.17 / Domínio Relações Sociais: 41.67 / Domínio Meio Ambiente: 56.25

\section{COMPREENSÃO CLÍNICA}

Lúcia tem uma postura séria e também um pouco distante. Durante os nossos encontros contou fatos de sua história, sempre com muita clareza e ordenação, embora demonstrasse estar pouco a vontade. As respostas à Escala Beck de Depressão indicaram ausência de quadro depressivo, mas evidenciaram sintomas como: sensação de fracasso e falta de prazer nas coisas, como apresentava anteriormente. Associamos esses sentimentos à sensação de mágoa que Lúcia diz ter com relação a acontecimentos marcantes em sua vida. Com relação ao WHOQOL, suas respostas indicaram qualidade de vida acima da média em relação a todos os domínios, com exceção ao que diz respeito às relações sociais. Esse resultado pode ser compreendido, se considerarmos, na fala de Lúcia, a ênfase na falta de apoio que sente das filhas, o que acaba comprometendo a sua qualidade de vida correspondente a esse domínio.

A aplicação do instrumento projetivo propiciou interação um pouco mais afetiva e próxima com Lúcia, que pareceu relaxar um pouco enquanto contava as histórias. Estas, em 
sua maioria, trouxeram cenas familiares e sociais vistas como felizes, e com personagens idosos que conseguem lidar de modo adequado com as questões do envelhecimento. Com relação à gravura 1, Lúcia demonstrou insegurança ao contar essa primeira história, preocupada com o "jeito certo de contar". No entanto, após o esclarecimento dado, ela pareceu ficar um pouco mais tranquila.

Podemos considerar que na história referente à gravura 15 que, segundo Bellak (1949/1992), suscita, entre outros, temas referentes às relações entre as gerações e também a ressentimento, à raiva e à desaprovação, Lúcia fez projeções que podem estar relacionadas à sua própria vida. Assim, ela conta uma história que retrata o momento da despedida dos pais e avós aos filhos e netos que se casaram. Lúcia, a partir desse enredo, trouxe o sentimento de tristeza dos pais ao ver a filha ir-se embora com o marido e da felicidade do casal devido ao casamento, mas ressalta que é uma tristeza que não permanece à medida que é possível recordar os bons momentos. A partir dessa história, podemos pensar sobre o sentimento de abandono ao qual Lúcia se referiu na entrevista, e também em uma capacidade de superação que ela demonstrou ter, após ter passado por momentos difíceis.

Podemos atribuir o distanciamento afetivo inicial de Lúcia a certa idealização da figura da psicóloga que, em sua fantasia, parece vir investida dos valores que atribui ao profissional que, por vir de São Paulo e da USP, pode lhe proporcionar crescimento, resgatando assim possibilidades que não conseguiu obter na vida do interior. Assim, as histórias de Lúcia frente aos estimulos do SAT parecem evidenciar suas defesas, revelando conteúdos que podem ser considerados mais sadios e construtivos juntamente com aqueles mais idealizados. 


\section{2 - Resumos das Sessões da Oficina Psicoterapêutica de Cartas, Fotografias e Lembranças ${ }^{13}$}

\section{PRIMEIRA SESSÃO}

\section{"Tem coisas na vida que a gente não conta para ninguém"}

Todos os participantes compareceram à primeira sessão. Sentamos-nos ao redor do quadro magnético, que nesse encontro inicial permaneceu vazio. Durante as entrevistas individuais, houve o convite para que trouxessem cartas, fotografias ou objetos, porém isso não aconteceu. Iniciamos a sessão nos apresentando. Nesse momento eles falam de si de uma forma bastante geral, abordando questões como idade, onde moram, alguns dados sobre a família, entre outras. A postura dos participantes, em geral, é tímida; há alguns momentos de silêncio e procuro estimular a retomada da conversa com algumas perguntas sobre o que eles trazem.

Percebo que se sentem mais à vontade quando começam a falar sobre as atividades de que participam no Grupo da Terceira Idade, e esse ponto em comum parece quebrar a tensão inicial. Clara e Lúcia contam sobre os cursos que já frequentaram e que, no ano passado fizeram um curso breve de teatro do qual gostaram muito. Angélica e Tereza falam das dificuldades em participar com mais constância. Lúcia destaca a qualidade das atividades e tece elogios à assistente social e à capacidade dela de organização e de dar atenção aos participantes. Todos concordam, inclusive Bento e Isa que haviam permanecido mais quietos até então.

Por meio da conversa que se estabelece, noto que, embora os participantes façam parte do Grupo da Terceira Idade, e já tivessem se visto ou mesmo conversado anteriormente, não há convívio entre eles. Eles se surpreendem com o fato de que, frequentando as mesmas atividades, praticamente não se conhecem. Lúcia disse que havia insistido para suas amigas mais próximas participarem, mas elas não demonstraram interesse; Tereza conta que o mesmo havia acontecido a ela. Ao me apresentar relembro algumas questões do enquadre sobre o qual havíamos conversado anteriormente nas entrevistas, entre eles o sigilo que devemos

\footnotetext{
${ }^{13}$ As fotografias que os participantes trouxeram às sessões foram alteradas com relação ao foco, com o objetivo de impedir a identificação das pessoas fotografadas.
} 
manter sobre o que conversarmos na Oficina. Enfatizo também o convite para que tragam cartas, fotografias e objetos sobre os quais queiram falar. Deixo claro ainda que, mesmo que não queiram trazer algo em determinada sessão, poderão participar; e que as lembranças podem também ser contadas e não necessariamente representadas em algo concreto.

Depois da minha apresentação, o grupo permanece em silêncio. Lúcia é a primeira a rompê-lo quando diz: "Sabe, é que é difícil falar assim da gente, tem coisas que a gente não conta para ninguém [...]" Tereza fala: "É verdade, estamos acostumadas a sermos alunas nos grupos, só recebemos, aqui acho que vai ser diferente [...]”. A partir daí, sinto todos mais a vontade. Isa diz que os problemas de família influenciam muito a vida das pessoas. Tereza começa a falar de sua preocupação com a família e acha que as modernidades, segundo ela, causam má influência nos netos. Nesse momento a conversa atinge um tom mais geral e a maioria dá sua opinião sobre, por exemplo, a influência da televisão, dos computadores e vídeo games entre os jovens. Tereza fala novamente sobre a dificuldade dos pais para controlar os filhos e a falta de uma voz mais ativa para com eles.

Procuro ampliar a questão, reforçando que esse é um espaço no qual eles podem falar sobre as suas vidas e sentimentos e digo: "Como vocês sentem isso na vida de vocês?" Angélica fala: "Os problemas da gente não são só de família, tem as mortes... Coisas que a gente não queria que acontecesse". Ela passa a falar sobre o processo da doença e morte do marido, e como sua vida havia ficado mais difícil desde então. Angélica nos conta que seu marido era uma pessoa muito boa e que, apesar das dificuldades financeiras, ele nunca havia deixado faltar algo a ela ou aos filhos. Todos ouvem em silêncio o relato de Angélica, que chora ao falar da saudade que sente do marido.

Clara diz entender o que Angélica sentia porque seu marido também era muito prestativo e dedicado a ela, mas que hoje, passado todos esses anos, ela estava mais conformada com a viuvez. Ao final da sessão, Clara pergunta se eu poderia ajudá-las a conversar com a assistente social para voltarem a ter aulas de teatro no Grupo da Terceira Idade. Digo que podemos conversar melhor sobre isso na próxima sessão e pensar se essa era também uma questão para o restante do grupo, o que achavam sobre isso. Clara concorda e encerramos a sessão. 


\section{SEGUNDA SESSÃO}

“O Apoio para o Sofrimento"

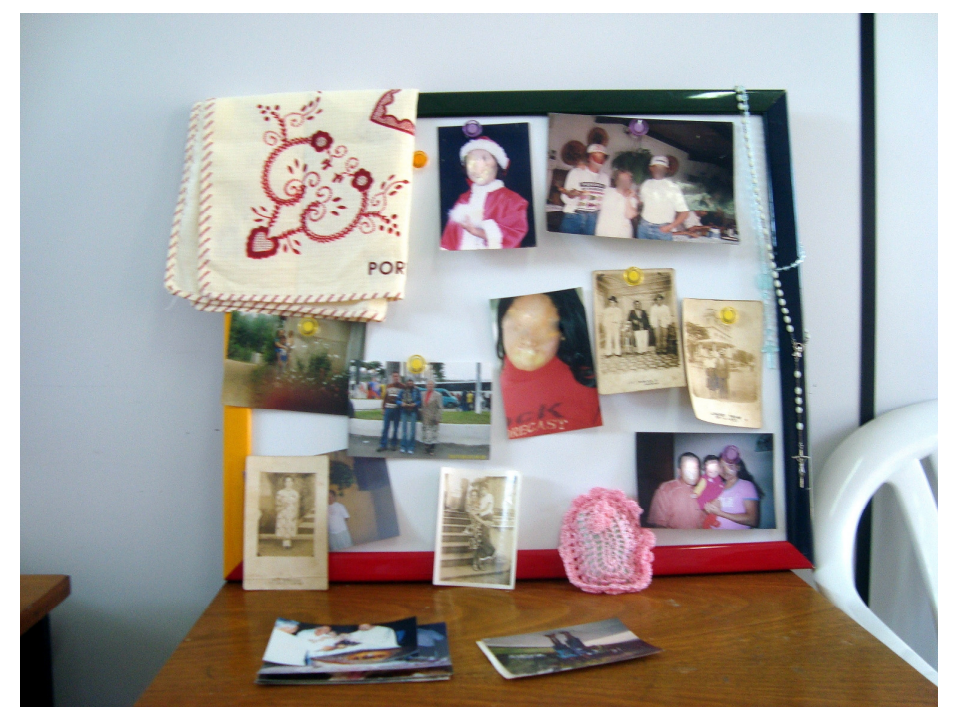

Sentamo-nos ao redor do quadro magnético e me ofereço para ajudar a dispor, nele e na mesa de apoio, as fotografias e os objetos que alguns participantes trouxeram. Isa, portando uma sacola com muitas fotografias, pede para que eu afixe algumas no quadro e outras apoie na mesa. Angélica trouxe um terço, um sabonete embalado em um trabalho de tricô e uma fotografia. Clara também trouxe fotografias, e Lúcia, um pano bordado que tem a palavra "Portugal". Aos poucos, o quadro vai ficando colorido.

Isa, de modo espontâneo, diz que tem se sentido muito triste. Aponta para uma fotografia e explica ser ela entre os dois filhos, alguns anos atrás. Conta sobre a morte recente do filho mais velho, o processo da doença dele, como sente sua falta, e sobre o fato de não se conformar com a morte tão prematura. Ela chora e sinto que os demais participantes também se emocionam. Conta que ainda não consegue fazer as coisas direito, nem tocar piano, o que a fez dispensar os alunos que tinha. Fala que a família lhe dá muita força e apoio, e por isso trouxe fotos de seus irmãos, do marido e netos. Nesse momento, ela pega as fotografias empilhadas sobre a mesa e começa a passá-las entre o grupo, descrevendo a família grande que tem, e mostrando fotografias em branco e preto de seus pais e irmãos, tiradas na fazenda onde morava. Alguns fazem perguntas sobre as pessoas e os locais retratados e Isa responde. Ao mostrar as fotografias ela parece menos angustiada que no início da sessão. 
Angélica comenta que também havia perdido uma filha e conta ao grupo como esse fato ocorreu. Ela fala: "Trouxe as coisas que são importantes, quando eu lembro quanta desgraça já passei [...] Mostra a fotografia de uma neta muito querida que ela criou até os 7 anos com quem, por circunstâncias relacionadas ao segundo casamento do genro, retomou o contato somente alguns anos atrás. Ela repete a história contada na entrevista inicial, enfatizando o quanto a segunda esposa do genro era ciumenta e impedia o contato dela e do marido com os netos. Mostra o terço para falar da ajuda que representa em sua vida a fé, e de como se sente bem ao frequentar a missa. Conta também que o trabalho de tricô foi feito por ela e que gosta muito de fazer artesanato e também de dar de presente o que faz, mas tem se sentido, nos últimos tempos, bastante desmotivada para novos trabalhos.

Pontuo para o grupo que tanto Isa como Angélica falam do grande sofrimento que sentem ao perder os filhos; mas, independentemente de quanto tempo atrás havia acontecido, trazem representado, nas fotos e objetos, o apoio que acreditam ter para poder lidar com esse sofrimento. Clara mostra as fotografias que retratam a filha, genros e netos e diz que a família é sempre o maior apoio na vida.

Lúcia, nesse momento, discorda de Clara, porque, acha que família não a apoia: "No men caso se eu for esperar pelo apoio da família estou roubada [...] Acabei tendo que fazer as coisas por mim. Queria muito ir a Portugal, juntei dinheiro e convidei minha irmã e ela não quis, ficou com medo de viajar para longe e deixar a família. Eu também fiquei com medo de ir sozinha. Acho que esse apoio tem que vir da gente mesmo. Esse paninho, uma amiga trouxe lá de Portugal."

Digo ao grupo, então, que cada um tem uma experiência diferente; que não há certo ou errado, mas sim o sentimento próprio de cada um, e assim vão podendo encontrar um sentido no que pode representar apoio com relação às dificuldades que enfrentam na vida. Assim, para alguns, esse apoio vem da família; para outros, vem dos amigos; e, claro, é muito bom quando sentimos esse apoio em nós mesmos. Falo também o quanto esse apoio parece ter o significado de não nos sentirmos sozinhos, principalmente quando atravessamos épocas mais difíceis. Exemplifico essa ideia com o material trazido por algumas participantes: Isa com as fotos da família, Angélica com o artesanato, o terço e a foto da neta, e Lúcia com a lembrança que representava, quem sabe, um sonho de ir um dia a Portugal.

Após a minha intervenção, todos parecem querer falar e opinar ao mesmo tempo. Tereza nos conta que sua família é do interior Bahia e que sente saudades dos irmãos que não 
vê há muito tempo. Conta que, há muitos anos, seu pai sofrera um derrame e ela conseguira ir visitá-lo na Bahia. Ele havia ficado com muitas sequelas e necessitava de cuidados constantes. Ela externa que se sentiu muito mal ao ter que voltar e ver o pai naquela situação. Pergunto sobre as condições do tratamento e se sua mãe tinha alguma ajuda para cuidar dele. Tereza responde: "Tratamento naquela cidade fim de mundo [...] Não tinha não. Não como tem aqui. Mandaram meu pai para casa e pronto, a gente que se arrumasse." Ela fala também que, quando precisou vir embora, brigou com alguns irmãos que, segundo ela, não queriam prestar maior ajuda para cuidar do pai doente. Conta que, alguns meses depois, ele faleceu. Senti Tereza ainda bastante ansiosa para falar do tema que trouxe, mas sinalizei que estávamos no final do nosso tempo e, assim, encerramos a sessão. 


\section{TERCEIRA SESSÃO}

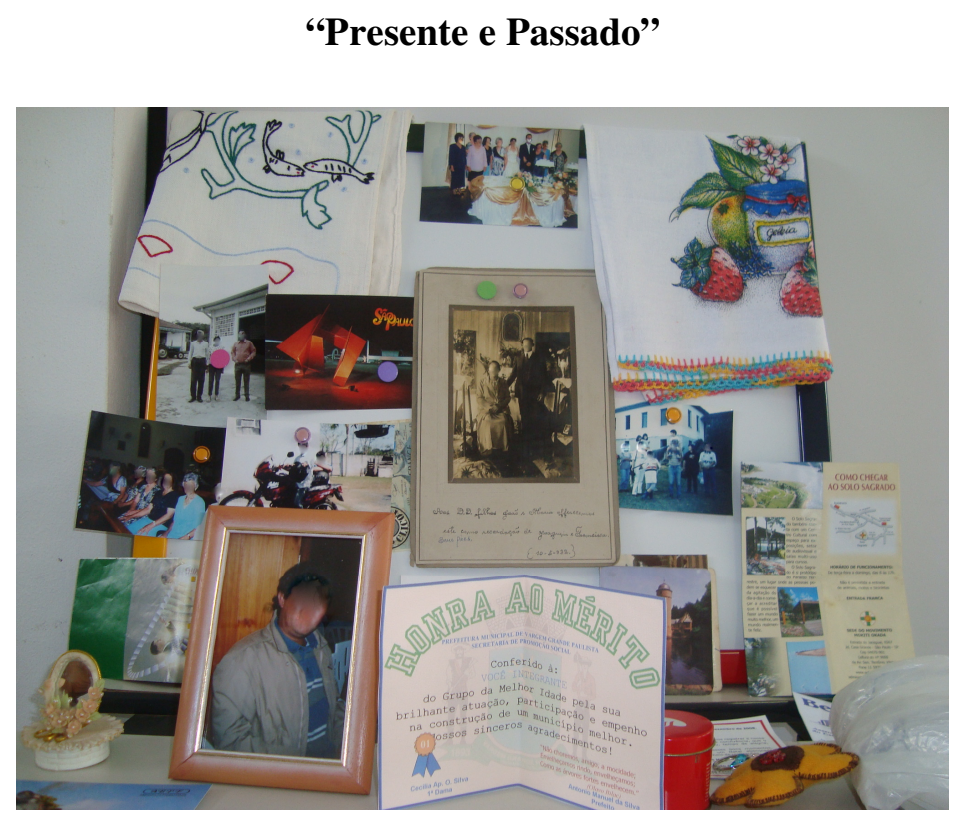

Iniciamos a sessão. Todos vieram à Oficina e vejo com satisfação que o quadro fica pequeno para tantas fotografias e objetos trazidos. Lúcia começa contando que trouxe um diploma de participação em uma atividade do Grupo da Terceira Idade. Conta sobre como foi difícil mudar-se de São Paulo para o interior. Sentiu-se muito deprimida na época, mas, depois da separação, as filhas casadas insistiram que seria bom que ela morasse próximo a sua irmã em uma cidade mais tranquila e com menor custo de vida, e ela acabou aceitando a ideia.

Diz que é muito grata ao Grupo da Terceira Idade, que a "salvou" naquela época, ocupando seu tempo com as atividades e proporcionando-lhe novos amigos. Trouxe também pequenas lembranças dos passeios com o grupo: a folha de uma árvore de um parque visitado, o ticket de uma lanchonete da cidade de Aparecida e um cartão postal da cidade de Santos, lembrança de uma viagem bastante recente, e algumas fotografias onde ela aparece ao lado de amigas do grupo. Falo que as lembranças que Lúcia traz, por meio da sua fala e também dos objetos e fotografias, parecem ser de ocasiões muito boas e recordadas com saudades. Se ela sentia as perdas advindas da mudança de São Paulo, que na época a deixara muito triste, era possível ver também muitos ganhos em ter vindo para o interior. Lúcia diz que, apesar de ainda preferir São Paulo, gosta da cidade onde mora hoje em dia, principalmente pelas amizades feitas. 
Angélica trouxe notas e moedas antigas guardadas em uma pequena latinha. Contou que resolveu esconder a caixa com o dinheiro para alguma eventualidade e, com o passar do tempo, esqueceu-se dela. Depois de muitos anos, achou a caixa, mas as notas e moedas já haviam perdido o valor; esse fato, na ocasião, fizera seu marido dar muitas risadas. Todos se divertem com a história de Angélica. Ela ainda mostra peças de artesanato feitas no passado: uma cestinha, uma flor de feltro e panos de prato pintados.

Clara trouxe uma fotografia, onde aparece ao lado do marido, e conta que ambos trabalharam como caseiros de um sítio, e gostavam muito dos antigos patrões. Mostra também o convite da primeira comunhão da neta. Bento, que até então havia permanecido quieto, tira uma chave do bolso e a coloca sobre a mesa de apoio, dizendo ser a chave de sua bicicleta motorizada, da qual gosta muito. Explicou que não conseguia pensar em algo para trazer; que tinha separado algumas fotografias, mas as havia esquecido em casa. Tereza diz que acha difícil esse negócio de trazer algo de casa para a sessão. Conta que gosta de ouvir as pessoas falarem sobre o que trouxeram, mas ela mesma ainda não havia conseguido trazer algo, embora pensasse nisso durante a semana. Clara fala que pensar sobre o que trazer à sessão é um jeito de lembrar-se do grupo durante a semana, das conversas, das pessoas.

Exponho minha concordância com Clara, acrescentando que cada um pode ter o seu jeito e seu tempo de lembrar-se das coisas. Alguns trazem fotos e objetos do passado, como as moedas de Angélica, ou do presente, como a chave da bicicleta motorizada de Bento; e outros, podem apenas contar suas lembranças, da forma como Tereza já fizera, ao lembrar-se da Bahia e dos irmãos por exemplo, sem, necessariamente, ter trazido algo.

Isa fala sobre as fotografias que trouxe: o filho e o neto com sua motocicleta; uma em preto e branco, de seus pais; e por fim outra, no porta-retrato, do filho já falecido. Diz que, por muito tempo, não conseguiu olhar para as fotografias do filho e que agora parece um pouco mais fácil. Acha que precisa, segundo ela: “[...] tentar lembrar sem sofrer tanto, aceitando mais o que aconteceu”. Lúcia, nesse momento, diz: “A gente não pode ter medo de olhar para o passado, ele é importante porque fez a gente chegar até aqui. Tem coisas que doem muito, como lembrar da traição do meu marido."

Digo a eles que, se olharmos para o quadro, vamos ver tanto lembranças do passado quanto objetos ou fotos de nosso presente, e que tudo isso faz parte de nossas vidas, assim como o que nós estamos conversando ali, naquele momento, pode fazer parte também de ações, pensamentos e sentimentos do futuro de cada um de nós. Todos voltam à atenção para 
o quadro, fazendo comentários sobre as fotografias e objetos e sobre como eram diferentes as fotografias antigamente se comparadas com as de hoje. Retomam o episódio do dinheiro de Angélica, que era do passado e hoje está aqui, mas só como recordação, porque havia perdido o valor, pois segundo Angélica: [...] de tão bem guardado acabou não sendo encontrado enquanto valia [...] A sessão termina de uma forma mais leve, com os participantes sorrindo ainda da história de Angélica. 


\section{QUARTA SESSÃO}

\section{"A História de Bento"}

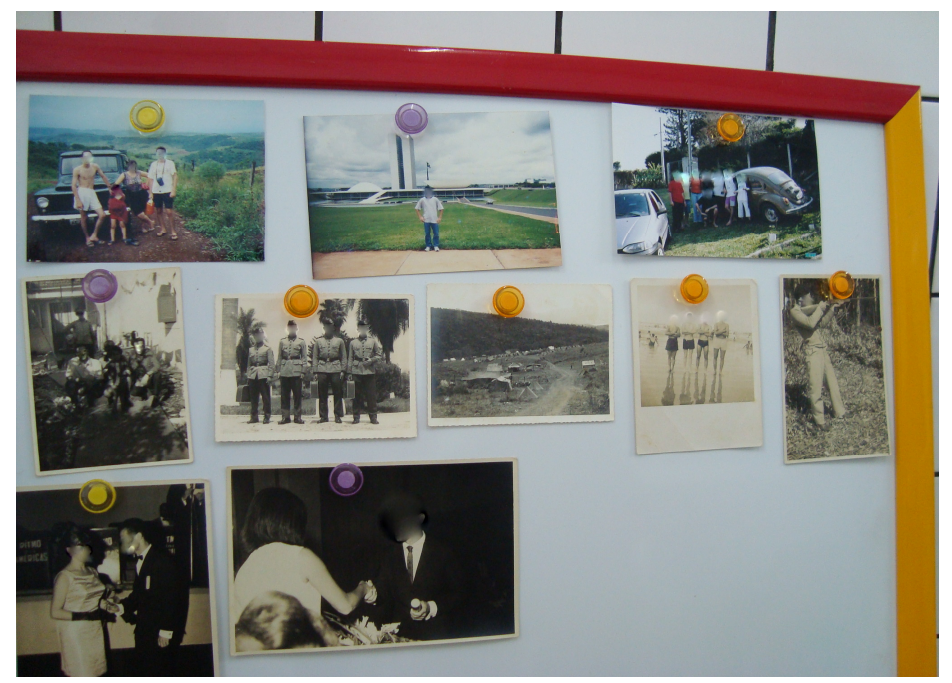

Todos estão presentes à sessão. Assim que nos sentamos, percebo que Bento trouxe muitas fotografias. Ele me pede para afixá-las no quadro. Tereza brinca dizendo que aquele seria o dia de Bento, pois, com a presença de tantas mulheres, era mesmo difícil ele conseguir falar. O clima é bastante descontraído e o assunto, por algum tempo, gira em torno das diferenças entre homens e mulheres com relação a falar mais ou menos, e outros temas afins. Angélica trouxe um anel e contou, enquanto o colocava sobre a mesa, que havia sido um presente do marido. Os demais participantes não haviam trazido material naquele dia.

As fotografias retratam Bento em várias épocas de sua vida e, em algumas, estão também a esposa e os filhos. Bento inicia explicando que a fotografia o mostra ainda adolescente, junto a amigos na praia, e como tem saudades daquela época tão despreocupada. Em seguida, fala do serviço militar e mostra a fotografia onde ele, fardado, está também com amigos, além de outras que retratam sua formatura no ensino médio em uma escola militar no interior de São Paulo.

À medida que fala sobre as fotografias, ele parece se sentir mais à vontade e intensifica o relato. Conta que sua mãe era dona de casa e seu pai havia sido militar e queria muito que ele seguisse a carreira. Durante a época em que cursou o colégio militar, embora tenha feito amigos e gostado da escola, achou que não era isso que queria para sua vida. $\mathrm{O}$ pai, segundo Bento, era pessoa bastante rigorosa e também muito fechada. Quando Bento 
comunicou-lhe a decisão tomada, ele não fez nenhum comentário, mas o olhou como se estivesse decepcionado e, durante muito tempo, passou a tratá-lo com frieza. A mãe o apoiou, mas mesmo assim Bento lhe disse se sentir muito culpado pela decepção causada ao pai. Embora já nessa época se interessasse por elétrica e pensasse em fazer uma faculdade de engenharia, não dispunha de condição financeira nem do apoio do pai. Bento desistiu da ideia e passou a trabalhar em fazendas com plantações e criação de animais.

Conta também que, quando casou, foi trabalhar com um sócio em uma fazenda. $\mathrm{Na}$ época, seu primeiro filho era recém-nascido e o sócio aplicou-lhe um golpe que o deixou completamente falido. Por isso, ele precisou pedir ajuda aos pais, e essa situação o fez se sentir muito humilhado. Bento fala que na época não conseguiu reagir, mas que, segundo ele, esse é um "grande sapo" que sente ter engolido na vida. Acha que, depois disso, engoliu ainda muitos "sapos", aceitando situações no trabalho com as quais não concordava, e calando quando deveria ter se manifestado. Bento conclui: "[...] acho que tudo isso acabou fazendo muito mal para meu coração e que meus problemas de saúde vêm disso". Diz também que acha que não deve mais engolir tantos "sapos", quer mudar. Pergunto para Bento porque ele acha que "engoliu tantos sapos" e ele responde: "Acho que eu não tinha coragem, me preocupava muito com o que as pessoas iam achar de mim, falar, eu acabava muitas vezes ficando quieto e isso ia me fazendo mal." Bento trouxe também fotografias mais atuais, principalmente de viagens com os filhos e a esposa. Fala que é bastante ligado na família e acha que a preocupação com seus problemas de saúde fazem-na sofrer muito. Sente-se responsável por isso, e, segundo ele, é um peso que carrega em sua vida.

Tereza passa também a falar sobre esse tema, relacionando seus problemas de saúde com coisas que deixou de falar ou fazer no passado. Outras pessoas do grupo se manifestam no mesmo sentido. Tereza acha que, atualmente, o seu problema é inverso, pois muitas vezes, segundo ela, "fala demais, o que não devia, e acaba saindo briga." O tema parece de fato mobilizar o grupo. Todos querem falar e, nesse momento, procuro mediar à conversa, de modo que possam se manifestar sem atropelos. Clara pensa que, às vezes, o melhor mesmo é não falar sobre o que incomoda e lembra o ditado: "[...] quem fala o que quer ouve o que não quer." Continuamos conversando sobre esse tema até o término da sessão. 


\section{QUINTA SESSÃO ${ }^{14}$}

"Mudanças"

Clara e Isa trouxeram fotografias, mas são ainda as de Bento que ocupam a maior parte do quadro. Bento trouxe, dessa vez, fotografias mais atuais: os aniversários dos filhos, formaturas, todos reunidos em pequenas comemorações familiares, viagens à praia e à casa de parentes no interior. Bento fala bastante dos filhos e do orgulho que sente por ter conseguido que se formassem na faculdade. Um deles é engenheiro, o que o deixa muito feliz, pois é a faculdade que gostaria de ter feito e não pôde na época. Diz, ainda, que os filhos são rapazes bons e responsáveis. Todos trabalham, têm namoradas; o do meio está noivo e deve se casar no próximo ano. Diz que os acompanha muito, mas eles reclamam do seu jeito fechado e gostariam que conversasse mais com eles.

Fala também da esposa: pessoa muito boa, mas também desconfiada; ela acha que seu jeito calado pode esconder segredos, coisas dele que ela não sabe. Cobra dele um comportamento mais aberto, onde possa falar o que está sentindo e dividir mais com ela. Bento diz que sente que, muitas vezes, ela e os filhos têm razão e que gostaria de mudar seu comportamento. Clara diz que acha que já está havendo essa mudança, pois ele que sempre foi tão calado estava contando tantas coisas sobre ele. Bento diz que de fato está se surpreendendo com o próprio comportamento, pois nunca havia se imaginado falando tanto sobre si para um grupo, como o fazia agora, e que se sentia muito bem com isso. Outras pessoas se manifestam, dizendo sobre o bem-estar que sentem em poder falar delas mesmas e que estão também gostando de participar da Oficina.

Bento coloca novamente, como fizera na terceira sessão, a chave de sua bicicleta motorizada ao lado do quadro e fala sobre o quanto gosta de andar com ela, principalmente porque sente uma sensação de liberdade. Conta que a bicicleta é como um "xodó" na vida dele: tem ciúmes e não gosta de emprestá-la a ninguém. Fala também sobre o receio que sente do médico proibi-lo de utilizá-la após a cirurgia. Todos se mobilizam após a fala de Bento. Tereza, bastante ansiosa diz: "Não vai ser nada não, quem sabe você nem precisa operar. Pelo menos no seu caso tem cirurgia, já no meu, acho, nem para operar dá [...]". Digo compreender a ansiedade de Tereza diante do tema que Bento traz, e sua necessidade de falar

${ }^{14}$ Esta sessão não possui registro devido a problemas técnicos com a máquina fotográfica. 
dos seus sentimentos, pois ela também sofre de problemas no coração. No entanto, procuro validar o sentimento de apreensão que Bento manifesta, encorajando-o a falar mais sobre isso.

Ele nos conta que soube, naquela mesma semana, que a cirurgia estava marcada para o início de janeiro, portanto a cerca de um mês. Bento passa a falar da cirurgia, dos exames a fazer e também de sua preocupação por ter que interromper sua participação no grupo, na época. Todas se mostram solidárias a Bento e procuram, por meio de perguntas e colocações, aliviar a angústia daquele momento. Digo a Bento que não se preocupasse com o fato de não poder participar do grupo em janeiro, e reforço que poderia continuar a contar com o nosso apoio também durante a fase da cirurgia.

Angélica fala que, ao se agravar a artrose que tem nos joelhos, precisou da bengala para se locomover. Disse que no início era muito ruim. Tinha vergonha e achava que as pessoas iriam achá-la mais velha do que realmente é. Com o passar do tempo, percebeu que a bengala a ajudava a andar melhor e que assim não sentia dores tão fortes; acostumou-se com o uso e, hoje em dia, não importa mais e acha que a bengala a ajuda bastante a não se limitar na locomoção. Falamos como muitas vezes é preciso se adaptar a mudanças em nossas vidas, e que algo, que a princípio pode ser encarado como ruim, pode aos poucos se transformar, mostrando-nos outros lados que não havíamos visto anteriormente. Alguns mais opinam sobre esse tema e encerramos a sessão.

\section{Nota sobre o ocorrido entre a quinta e sexta sessão}

A última sessão relatada ocorreu em uma sexta-feira. No domingo, durante a tarde, Bento sofreu um ataque cardíaco e faleceu. A esposa e os filhos tentaram levá-lo para o hospital da cidade e, lá chegando, tentaram reanimá-lo, porém sem sucesso. A coordenadora do Grupo da Terceira Idade entrou em contato comigo na segunda-feira, colocando-me a par do acontecido. Disse-me que todos haviam ficado muito tristes com o fato e que muitos participantes do Grupo da Terceira Idade estiveram no velório e no enterro que ocorrera naquele dia pela manhã. Eu disse a ela que estaria na próxima sessão marcada da Oficina com o grupo para podermos conversar sobre o acontecido. 


\section{SEXTA SESSÃO}

\section{“Há uma cadeira vazia aqui”"}

Fui à sessão bastante impactada com a morte repentina de Bento. Todas estavam presentes, mas nenhuma das participantes havia trazido fotografias ou objetos, como que sinalizando que aquela seria uma sessão para conversarmos sobre o que havia ocorrido. Chama à atenção a cadeira vazia posicionada ao lado de Lúcia. Todas estavam presentes e, antes mesmo que eu perguntasse sobre os seus sentimentos, elas espontaneamente passaram a falar sobre o que acontecera. Isa, Clara e Lúcia haviam ido ao velório, falaram da tristeza da esposa e filhos. Todos lamentavam muito que não houvesse tempo para a cirurgia cardíaca. Angélica conta que soube que ele, a esposa, os filhos e duas das namoradas, estavam reunidos no almoço de domingo. Após o almoço, Bento foi até o quintal da casa e lá teve o enfarte.

Clara fala que sente que Bento aproveitou bastante o grupo, principalmente as últimas sessões quando pôde falar bastante sobre si. Lúcia concorda e fala que todas devem ter sentido como foi importante para ele mostrar as fotografias e falar sobre elas, pois nas duas últimas sessões ficaram mais caladas, como se, de fato, o espaço fosse dele. Clara relembra a sessão na qual Bento havia falado sobre os "sapos" que havia engolido na vida e de como não queria mais que isto acontecesse. Lúcia diz que, embora seja católica, deixou naquele dia uma cadeira vazia para Bento, como se fosse um símbolo, um jeito de dizer que na lembrança ele sempre fará parte deste grupo. Todos concordam e sinto que encaram essa atitude realmente como uma homenagem a Bento.

Tereza, que estava bem mais quieta do que nas últimas sessões, disse que tinha ficado muito impressionada com a morte de Bento e como era estranho estar com a pessoa e de repente esta não estar mais lá. Diz que ficou com muito medo também, devido aos seus próprios problemas de saúde. Digo que é natural que ficasse impressionada, pois ela também tinha problemas cardíacos e havia se identificado com a possibilidade de que lhe acontecesse o mesmo. No entanto, reforço o foto de Tereza estar se cuidando, vindo às sessões, e que isso é muito importante. Clara fala que é difícil entendermos o porquê isso aconteceu, qual a explicação, por que uma pessoa boa, como Bento, morre e outras ruins ficam vivas. Isa fala: "O mais difícil é a gente se conformar sem saber a razão. No caso do meu filho eu também não entendo, uma pessoa tão jovem, que só fazia o bem, sofrer tanto e morrer cedo.”. Falo da nossa impotência perante algo tão difícil como a morte e da necessidade que temos de 
compreender algo para alívio do nosso sofrimento, e que essa busca de sentido é algo que cada um vai fazendo dentro de si, aos poucos na vida, cada um há seu tempo.

Surpreendo-me com a capacidade dessas mulheres lidarem com essa perda. Elas estão tristes, mas não choram; seguem falando sobre o tema e muitas delas estão falando de mais uma perda que se soma a tantas outras em suas vidas. Angélica passa a falar de sua viuvez e de como é difícil, segundo ela, "[...] da noite para o dia ficar sozinha, porque mesmo doente meu marido estava lá.”. Clara, que teve a mesma experiência, concorda, mas diz que no seu caso não foi tão difícil se adaptar, pois sempre procurou ser mais independente. Lúcia relembra a separação do marido que foi, em suas palavras, "como também ficar viúva da noite para o dia", pois, depois da traição e do abandono, ela sentia que aquele marido que ela conhecia havia de fato morrido para ela. Isa fala mais sobre a morte do filho. A sessão termina com todas opinando sobre a viúva de Bento e avaliando como acham que será difícil a vida dela dali em diante. 


\section{SÉTIMA SESSÃO}

"Mágoas: uns choram e outros não"

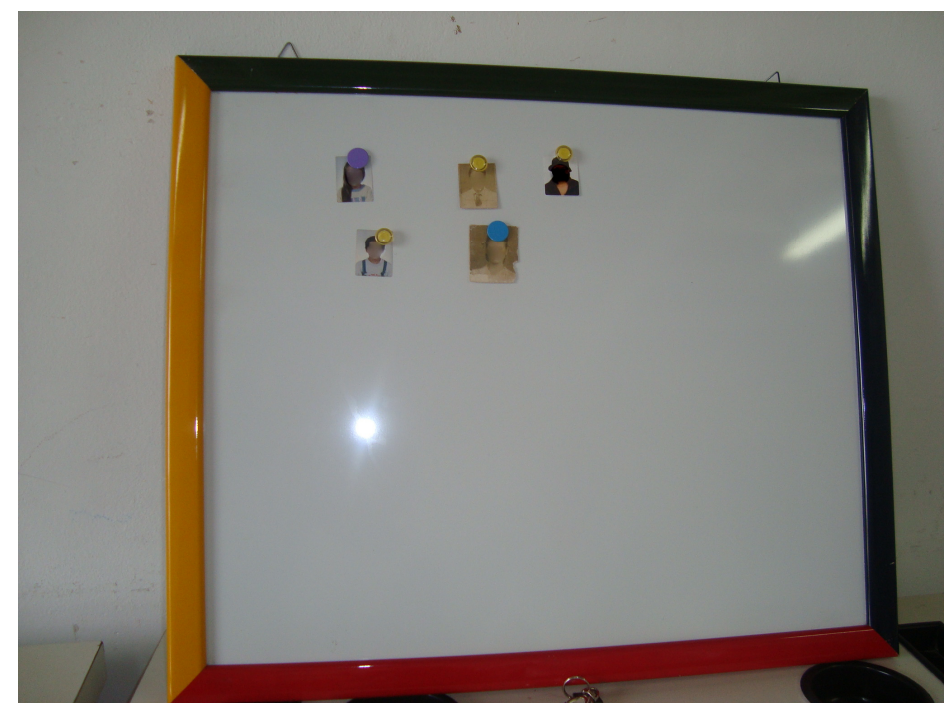

Todas estão presentes à sessão. Clara, Tereza, Lúcia e Isa se desculpam por não terem trazido nenhum material. Angélica trouxe uma pulseira e duas fotografias pequenas em preto e branco. Clara comenta que hoje o quadro não estava tão cheio e bonito como em outras sessões; em seguida, tira duas fotografias pequenas da bolsa e as afixa no quadro. Angélica tira da carteira uma fotografia $3 \times 4$ e a coloca no quadro.

Angélica conta que havia ganhado aquela pulseira do marido há muitos anos; estava chateada porque imaginou dá-la de presente para a neta mais velha, mas ela não vem visitá-la há muito tempo. Ela fala: "[...] às vezes, as pessoas me acham boazinha, mas eu não sou boba, não aprendi ler nem escrever, mas sei da vida, não vou deixar que ou outros me enganem". Mostra a fotografia da neta que ajudou a criar, e que a visita com mais frequência, dizendo que, embora a neta mais velha vá ficar brava, ela vai dar a pulseira para a da fotografia. Mostra também a fotografia do marido e da filha falecida. Angélica conta ainda que, no mesmo terreno de sua casa, há uma igreja evangélica e que o Pastor pretende reivindicar sua casa como parte do terreno. Angélica diz que se sente muito magoada com isso, mas que vai lutar porque a casa é dela.

Clara mostra as fotografias dos netos e diz que alimentar mágoas não leva a nada, pois segundo ela, “[...] mágoa faz mal para a gente, é melhor deixar, viver bem”. O tema do grupo 
passa a girar em torno das mágoas que têm e de como cada um reage a ela: alguns choram, outros sentem raiva, e assim por diante. Tereza diz que não concorda com Clara, pois tem coisas que a magoam muito: "[...] eu não levo desaforo para casa, pode ser filho neto ou marido, quando tem alguma coisa errada, fico com raiva e falo mesmo. Só depois que vem a tristeza. Não quero ficar engolindo sapos como o nosso amigo Bento falava."

Isa conta que, quando se sente magoada, sua reação é diferente, pois ela chora e muitas vezes só consegue falar sobre o assunto muito tempo depois. Lúcia, por sua vez, diz: “[...] acho que a maior arma para quando a gente é magoada é a indiferença com a pessoa. É como com as minhas filhas, que nunca têm tempo para vir me visitar ou me levar para passear em São Paulo. Fico muito magoada, mas não demonstro, tenho o meu orgulho."

Isa lamenta pelo filho mais novo não "guardar um luto mais tempo pelo irmão." Conta que ele, algum tempo depois do falecimento, já tinha ido com a família em um churrasco de amigos, em um sítio. Na época, ele insistiu para que os pais também fossem, mas Isa considerou isso um desrespeito com a memória do filho. A opinião geral foi de que os mais jovens têm uma ideia diferente do luto; não era como antigamente, quando as pessoas respeitavam mais. Lúcia fala que acha que ele poderia estar sentindo tristeza pela morte do irmão, mas com um jeito diferente de demonstrar. Lembram-se, novamente, de Bento, que dizia não demonstrar muito o que sentia; mas, como nos havia contado, isso não queria dizer que ele não tivesse sentimentos.

Ao final da sessão falo sobre como cada uma de nós é diferente da outra na forma de ser; que frente a um sentimento de mágoa, agimos, cada uma, de um jeito; umas ficam tristes e choram, e outras têm raiva, ficam bravas; muitas vezes, experimentamos os sentimentos misturados. No entanto, via a importância de sermos nós mesmas, respeitando os nossos sentimentos e agindo de forma coerente com eles, sabendo que sempre há uma consequência para as nossas ações. Elas concordam e permanecemos conversando sobre esse assunto até o final da sessão. 


\section{OITAVA SESSÃO}

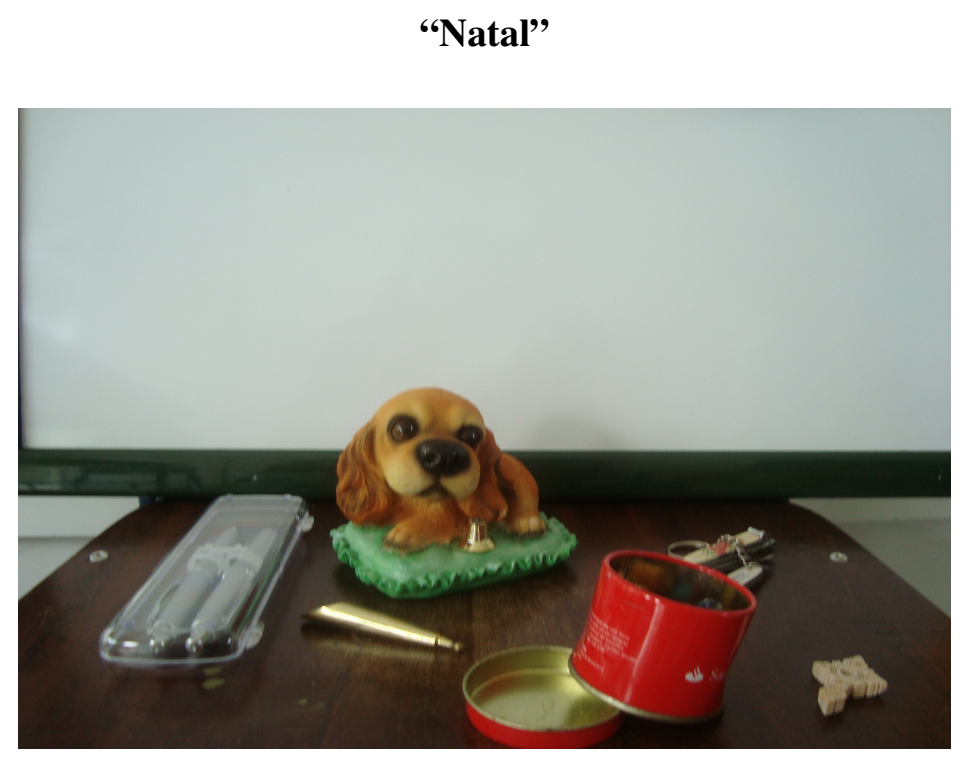

É a nossa última sessão do ano; estavamos próximos ao natal. Elas me trazem um presente comprado em conjunto: um estojo com canetas e um cachorro de cerâmica que também é um suporte para caneta. Após o meu agradecimento, sugerem que eu coloque o presente na mesa de apoio. Angélica traz ainda um crucifixo feito de madeira e um chaveiro, além da mesma latinha com as moedas e notas antigas que já havia trazido em uma sessão anterior. Não há fotografias.

Iniciamos a sessão com Clara contando, com entusiasmo, sobre a festa de natal do Grupo da Terceira Idade. Elas falam sobre detalhes da comemoração, do amigo secreto, dentre outras coisas. Falam também sobre os preparativos para passar o natal com suas famílias. Isa diz que, apesar da data, não se sente tão mal ao lembrar-se do filho. Ainda chora bastante, mas se recupera mais rapidamente. Clara comenta que, quem sabe, nesse natal Isa consiga até tocar seu piano, como disse que fazia antigamente. Isa sorri e não responde.

Tereza se lembra de Bento, pois viu a esposa dele, na semana, com uma aparência muito triste. Pergunto sobre a saúde de Tereza e ela conta que tem se sentido muito cansada e indisposta; às vezes se esforça para estar presente, tanto no Grupo da Terceira Idade quanto em nossa Oficina, mas sente que faz bem a ela e, por isso, não quer perder ambos os encontros. Conta também que acha que melhorou um pouco da depressão, não fica tão desanimada, apesar de considerar a época de natal muito triste. Ela foi à consulta com o 
psiquiatra recentemente e este mudou o remédio que tomava para a depressão, segundo ela, por um mais fraco e que não lhe faz tanto mal. Explica que agora está tomando a medicação regularmente e que, no geral, está se dedicando mais a seus tratamentos de saúde, sem reclamar tanto como fazia antigamente. Digo que, o ocorrido com Bento nos marcou a todas e que, sem dúvida, nos fez repensar sobre as nossas vidas, como Tereza, por exemplo, que parece estar se cuidando melhor.

Angélica diz que não gosta do natal, e ainda fica muito triste com a morte do marido. Mostra um chaveiro que era dele e também o crucifixo comprado em uma viagem que ela e marido fizeram com o Grupo da Terceira Idade. Ela chora, dizendo que passará o natal com a família do filho doente, mas que, apesar de achar bom estar com ele, sabe que, quando sua família se reúne, há muitas brigas. Fica preocupada também com o filho que bebe muito, que nessas ocasiões exagera ainda mais. Lembra-se do genro que fora casado com a sua filha falecida, e conta como ele era totalmente dominado pela atual esposa que, muito ciumenta, impedia-o de visitá-la, mesmo no natal. Conta que a neta que havia criado (filha de sua filha falecida) viria visita-lá e isso era bom.

Lúcia diz que vai passar o natal com uma irmã que mora em uma cidade do interior mais distante e está animada com essa perspectiva. Isa fala que, logo após o natal deve ir para Minas Gerais passar o ano novo com a família, e que também está gostando da ideia de viajar. Passam a falar das festas de final de ano e como essa é uma época triste para quem perdeu alguém.

Pergunto como será a passagem do ano para elas. Angélica diz que não liga muito para isso: "no dia seguinte está tudo igual, é bobagem isso de ano novo". Para Isa: "a farra é mais das crianças e dos jovens com os fogos e festas". Clara relata que é uma época de muito trabalho, porque é ela que acaba indo para a cozinha, muitas vezes, sem tanta ajuda das noras e filhas. Todas concordam que o mesmo ocorre com elas. Elas brincam dizendo que no final todos querem comemorar, mas o trabalho em cozinhar fica mesmo para elas. No entanto, elas complementam que gostam de cozinhar. Lúcia pede à Isa a receita do doce que fizera para a festa de natal do Grupo da Terceira Idade. Combinamos o nosso retorno para a primeira semana de janeiro e nos despedimos em um clima festivo. 


\section{NONA SESSÃO}

\section{"Estamos aqui de volta"}

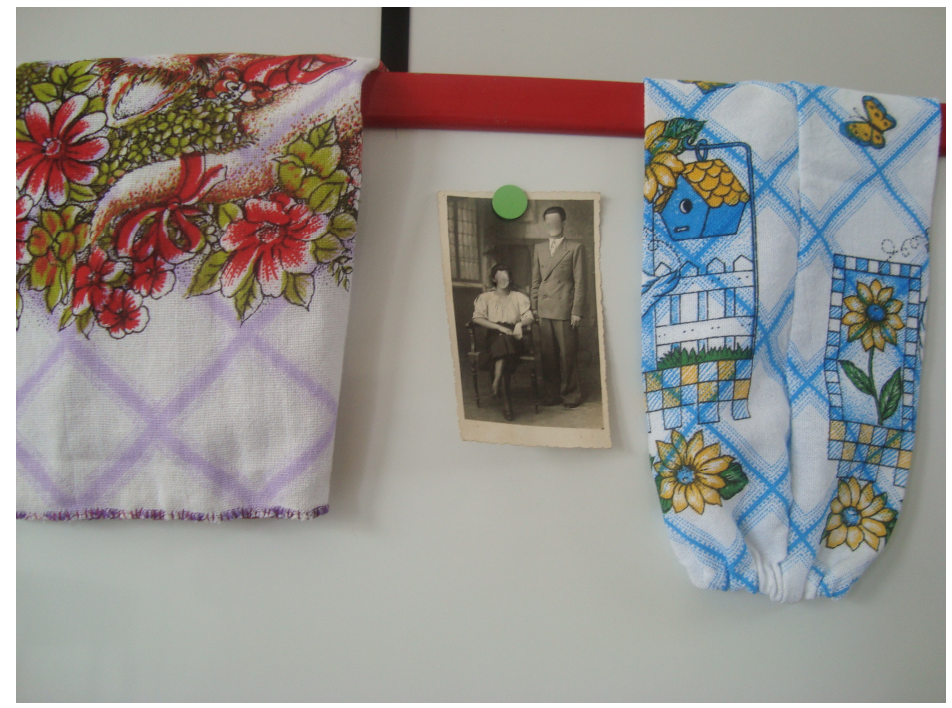

Permanecemos duas semanas sem sessões da Oficina devido às festividades do final do ano. Compareceram somente Angélica e Clara. Isa, Tereza e Lúcia ainda estavam viajando e deveriam retornar na próxima sessão. Angélica traz um saquinho pintado com flores e borboletas para guardar sacolas plásticas, e Clara, um pano de prato pintado à mão, ambos feitos por elas. Elas se surpreendem com a coincidência de terem pensado em algo semelhante para trazer à sessão. Clara traz também uma fotografia bastante antiga de seus pais, quando eram mais jovens.

Clara diz que está gostando de estarmos de volta, no grupo, para começar mais um ano e Angelica concorda. Dizem que é estranho somente as duas estarem presentes para falar, e que sentem falta do grupo. Clara, parecendo preocupada com a minha impressão sobre somente as duas estarem presentes, fala: "O importante é que a gente está aqui de volta, logo o grupo fica cheio de novo". O assunto versa sobre como foi, para cada uma, o período de Natal e ano novo. Angélica diz que, tal qual ela havia comentado na última sessão, houve algumas brigas, principalmente entre duas noras que não se dão bem e também entre seus filhos. Ela conta que está preocupada, pois acha que o filho que mora com ela está bebendo muito e, consequentemente, está ameaçado de perder o emprego. Na noite de Natal esse comportamento se repetiu e um de seus filhos brigou muito com ele, chegando até a agressão 
física. Ela fala também que, em horas como essa, sente muita falta do marido, pois os filhos o respeitavam muito e jamais, segundo ela, brigariam dessa forma na presença dele.

Clara pergunta sobre a possibilidade de tratamento para o alcoolismo do filho de Angélica, e esta fala que o filho não admite ajuda, pois não reconhece o problema. Falamos da sensação de impotência que, muitas vezes, temos diante das escolhas que não são nossas e como não podemos mudar as pessoas, embora seja importante mostrar também os nossos limites em determinadas situações. Angélica acrescenta que, quando se trata de filhos, é muito difícil porque eles não são mais crianças. Angélica também compartilha o sofrimento com a doença do filho, que está com câncer no intestino e tem uma cirurgia marcada para breve. $\mathrm{O}$ filho mora com a família na mesma cidade, mas na zona rural, em uma região de difícil acesso. Ela fala: "[...] queria cuidar do meu filho, mas ir na casa dele é difícil e não posso deixar a minha casa para ficar com ele, estou com muita dor na artrose e está ruim para andar muito".

Retomo a questão da sensação de impotência frente a algo tão difícil quanto à doença do filho, e conversamos sobre outras possibilidades dela ajudá-lo, por exemplo, pedindo para que outro filho a leve de carro para visitá-lo aos domigos. Angélica diz que havia pensado em ficar morando algum tempo com esse filho, a nora e os netos, para ajudar nos cuidados póscirúrgcos. A nora trabalha muito, assim como os netos adultos, e ela poderia ser muito útil. Fica, porém, bastante preocupada com a sua casa e acha que o pastor da igreja pode mandar invadir seu terreno na ausência dela, pois o filho que mora com ela só está em casa à noite.

Clara ressalta que é uma decisão difícil mesmo, mas que ela tinha de pensar primeiro em seus problemas, pois o filho, apesar de tudo, possuia uma família com muitos filhos e netos para ajudá-lo. Fala também: acho que a dedicação que a gente tem, nem sempre a família tem com a gente. Pergunto se ela tinha esse sentimento com relação à sua família e Clara respondeu: “Às vezes tenho. Eles me tratam bem, mas às vezes parece que não tenho muita importância, fico lá, ajudando a cuidar da casa”. Já estamos no final da sessão e Clara fala brevemente sobre a fotografia de seus pais, que trouxera. Conta que a mãe era muito vaidosa, gostava de se arrumar e aparecia sempre bonita nas fotografias. Já seu pai era mais sério e bravo, como podíamos notar em suas feições na fotografia. Clara promete trazer a mesma fotografia em outra sessão. 


\section{DÉCIMA SESSÃO}

\section{"Um grande mosaico"}

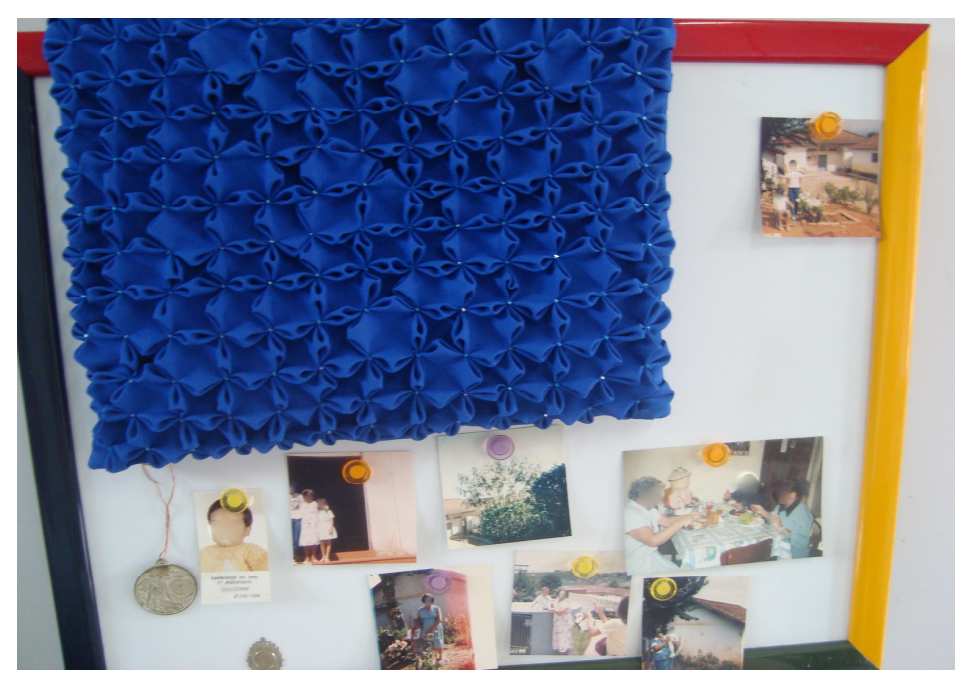

Todas comparecem e trazem muitas fotografias e objetos à sessão. Isa traz uma medalha que o filho falecido havia ganhado quando pequeno, e uma medalhinha religiosa. Lúcia veio com fotografias das festas de final de ano que passou com a irmã. Angélica traz a capa de uma almofada feita de fuxico, confeccionada por ela. Tereza traz fotografias dos filhos quando pequenos. Clara também traz fotografias dela com os netos. Todas estão agitadas e falantes e o tema central são as viagens e festas do final do ano.

Isa mostra a medalha, lembrança do filho quando pequeno. Fala bastante dele e comenta que a cada dia, embora a dor esteja lá, consegue se sentir um pouco melhor. Não se considera preparada para voltar a dar aulas, mas já consegue tocar um pouco de piano. Ela conta sobre a viagem para Minas Gerais, feita com o marido e a família de seu filho mais novo. Disse que gostou muito de rever os irmãos e que todos foram muito carinhosos com ela; e que trouxe, para mostrar ao grupo, a medalhinha religiosa, presente de uma de suas irmãs. Conta que foi à missa com os irmãos, e que se sentiu muito bem e reconfortada, pois se lembrou de quando eram pequenos e iam à igreja, na cidade, todos os domingos.

Lúcia mostra as fotografias e fala de sua viagem para a casa da irmã, também foi boa, e lá se sentiu bem acolhida pelas sobrinhas e pelo cunhado. Ela conta também que acabou desabafando bastante com essa irmã, falando da mágoa que tem das filhas, e a irmã pôde fazer o mesmo com ela, o que foi muito bom. Fala que o cunhado foi bastante atencioso e fizeram 
vários passeios. Sentiu saudades das filhas e netos, mas conseguiu falar com eles no natal, pelo telefone, pois estavam viajando para lugares distantes.

Todas elogiam a capa de almofada feita de fuxico por Angélica. Por algum tempo a conversa gira em torno do artesanato e da técnica do fuxico. Clara comenta que Angélica é muito caprichosa, pois tudo que traz à Oficina, feito por ela, é bonito e bem feito. Todas concordam, com vários elogios. Percebo que Angélica fica muito feliz com as manifestações do grupo. Ela conta que desde pequena gostava de artesanato, mas como sempre precisou ajudar na lavoura, não tinha oportunidade de fazer algo nesse sentido. Ela foi aprender artesanato depois de adulta, praticamente sozinha, e conta ao grupo, bastante constrangida, que o que gostaria mesmo é de aprender a ler e a escrever, mas acha que agora está muito velha e não vai conseguir fazê-lo. A sua fala gera uma reação de discordância geral no grupo e todas a incentivam a se alfabetizar. Lúcia fala: "[...] tenho certeza que você aprende muito fácil, tem cursos à noite na cidade”. Angélica sorri e diz: “[...] quem sabe... Vou pensar".

Clara mostra uma fotografia onde está ao lado dos netos. Conta que sua filha e a família planejaram ir para a casa de parentes de seu genro, por uma semana, em outra cidade, e queriam que Clara os acompanhasse. Ela ponderou com a filha que não gostaria de ir por não se sentir tão a vontade na casa de outras pessoas com quem não convive; além disso, não pretendia perder a sessão da nossa Oficina. Essa situação gerou um grande problema, pois a filha não queria que ela ficasse sozinha na casa e insistiu muito para que Clara mudasse de ideia. No final, a família foi viajar e Clara permaneceu em casa. Tereza diz que Clara é corajosa de ficar sozinha e que ela teria medo. Clara respondeu que não sentia medo. As outras participantes também opinam. Algumas acham que Clara deveria ter ido com a família e outras, não. Digo a elas que essa é uma situação que mostra como cada um pensa e sente de forma diferente e como havia sido importante Clara dizer o que sentia para a família e conseguir tomar uma atitude coerente com o seu sentimento.

Tereza também mostra suas fotografias e fala do seu final de ano. Conta que, na véspera de natal, se sentiu mal, com falta de ar e taquicardia, e que todos da família se preocuparam bastante, poupando-a de qualquer trabalho. Ela diz que, no entanto, foi algo passageiro, e no dia seguinte já se sentia melhor, tanto é que acabou indo passar alguns dias na casa de parentes, em uma cidade vizinha. Estávamos quase no final da sessão e Lúcia falou: "Nossa, falamos tanto em artesanato que o quadro hoje está parecendo quando a gente 
faz mosaico de artesanato, são várias partezinhas de cada uma de nós. São pecinhas diferentes, mas que depois junto fica bonito." 


\section{DÉCIMA PRIMEIRA SESSÃO}

“Uma boneca muito especial”"

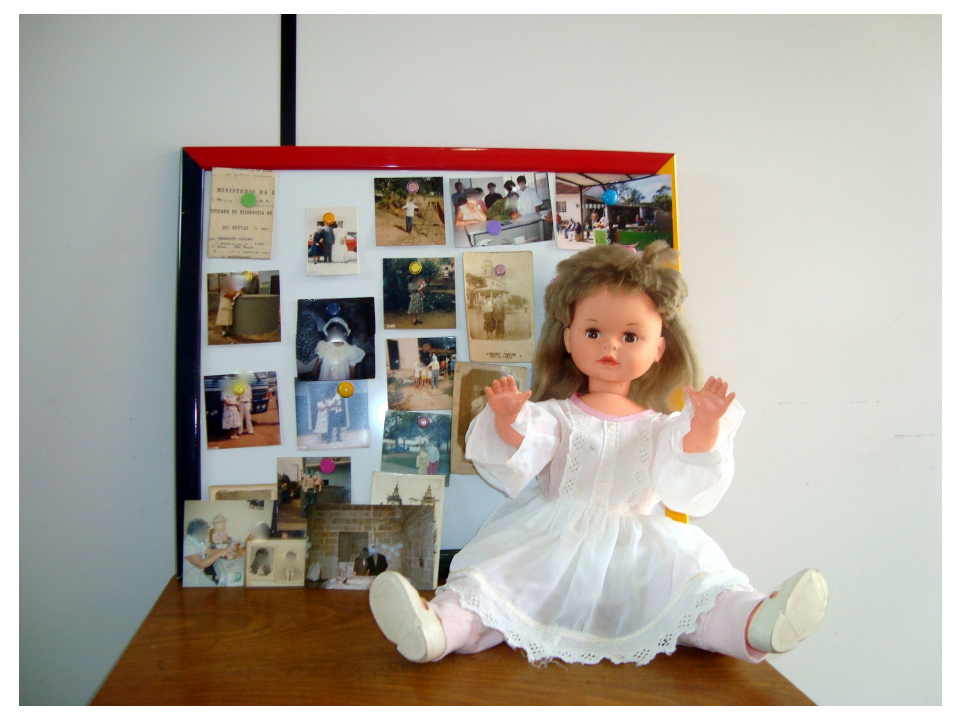

A sessão já havia começado. Todas, com exceção de Angélica, estavam presentes e trouxeram fotografias. Tereza traz também sua certidão de nascimento. Colocamos as fotografias no quadro e, quando íamos começar a conversar, Angélica chega, atrasada, carregando com dificuldade uma sacola muito grande. Para nossa surpresa, tira da sacola uma boneca grande e bonita e a coloca sobre a mesa. Todas, com bastante curiosidade, pedem para que ela fale sobre a boneca.

Angélica nos conta que a boneca está com ela desde os dezesseis anos e que, embora já tenha emprestado para as filhas e netas brincarem, faz questão de ter muito cuidado com ela. Angélica relata sobre sua infância, muito pobre. Ela, que trabalhava na lavoura com os irmãos e os pais, nunca havia tido uma boneca de verdade, só algumas feitas de sucata ou palha de milho. Que naquela época, ter uma boneca de verdade, para a realidade dela e das irmãs, era muito difícil, pois somente pessoas mais ricas tinham brinquedos de verdade, comprados em lojas. Quando ela fez dezesseis anos, seus pais, segundo ela, arranjaram o seu casamento com o filho de um vizinho, alguns anos mais velho, de quem gostou. Ele veio a ser seu marido por todos esses anos. Sua vida era muito dura na época e ela tinha a esperança de que o casamento mudasse as coisas. 
Ela conta que, próximo à data do casamento, disse ao noivo que seu maior desejo sempre foi o de ter uma boneca de verdade. No dia do casamento, quando entrou no seu quarto, em cima da cama estava a camisola da noite de núpcias, dada pela mãe, e a boneca comprada pelo marido para ela. Esse foi um momento do qual, segundo ela, nunca iria se esquecer. Desde então a boneca a acompanha em sua vida. Ela diz: “[...] depois que meu marido morreu fiquei mais apegada a ela ainda. Meu marido era assim, gostava de agradar, dar presentes. Foi assim a vida toda. Eu trouxe aqui algumas coisas que ele me deu. Nós éramos pobres, mas ele nunca esquecia um aniversário, sempre vinha com um presentinho, às vezes até mesmo sem motivo."

Todas se interessam muito pela histórica de Angélica e comentam como a boneca é bem cuidada e conservada. Lúcia observa que ela teve muita sorte de os pais terem escolhido um marido tão carinhoso para ela. Tereza concorda e fala que muitos casamentos arranjados não dão certo, e que ela teve mesmo muita sorte. Lúcia relembra o seu casamento e diz que o marido nunca havia sido tão atencioso com ela; que era uma pessoa mais fechada e voltada para o trabalho. Angélica fala que, desde o dia em que a ganhou até hoje, a boneca fica em cima da sua cama, enfeitando. Gosta de olhar para ela porque lhe traz recordações de muitas coisas boas. Quando sua única filha nasceu, a sogra lhe disse que quando ela crescesse poderia herdar a boneca. Angélica conta que nessa ocasião ficou muito brava com a sogra e respondeu que poderia emprestá-la para a filha, mas não dar, porque a boneca pertencia a ela. Ela educou a filha e depois as netas para pedirem a boneca emprestada para brincar e depois devolvê-la, e conta que nunca houve problemas com relação a isso. Digo que possivelmente elas deviam sentir a importância que Angélica dava à boneca e, por isso, tomavam cuidado. Angélica concorda.

Tereza mostra sua certidão de nascimento contando que, ao procurar lembranças para trazer à Oficina, achou o documento. Lê para o grupo o nome da sua cidade natal, no interior da Bahia, e disse ter muitas saudades de lá, principalmente de alguns irmãos que ainda residem no local e que ela não vê há bastante tempo. Isa trouxe fotografias da família de seu marido e fala das lembranças que elas despertam. Fala do bom relacionamento com a sogra e com as cunhadas; pessoas boas, com as quais nunca tivera problemas. Lúcia conta que nunca se deu bem com a sogra. Ela protegia muito o marido e Lúcia sentia que ela tinha muito ciúmes. Quando ela se separou, a sogra já havia falecido, mas ela acredita que, se estivesse viva, não a teria apoiado nos momentos difíceis pelos quais passou. 
Chegamos ao final da sessão e todas se aproximam da boneca, para vê-la mais de perto. Ajudam Angélica a colocá-la na sacola e se mostram preocupadas em como ela iria carregá-la, pois estava chovendo. Clara e Lúcia se oferecem para ajudá-la a levar a sacola até o ponto de ônibus. 


\section{DÉCIMA SEGUNDA SESSÃO}

\section{“Quero contar um segredo"}

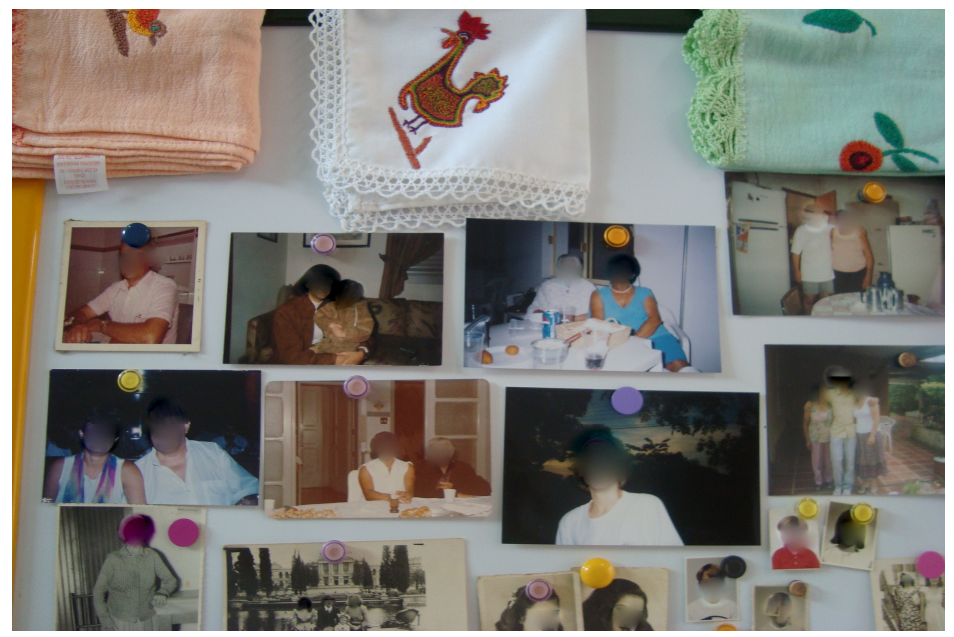

Nesta sessão Lúcia, Tereza e Isa trazem fotografias. Angélica traz toalhas que pintou e bordou. Clara traz fotografias suas, em várias fases da vida. Todas comentam como ela era uma moça bonita. Clara conta que, de fato, era muito assediada pelos rapazes e, em certa ocasião, ficou gostando de um que sua família não aprovava, pois ele, além de ser mais velho, tinha fama de mulherengo.

Nesse ponto da história, Clara silencia e, depois, diz que vai contar um segredo, do qual tem muita vergonha e que poucas pessoas sabem. Parece bastante constrangida, mas as demais participantes a incentivam e a apoiam, dizendo que todos têm seus segredos e que pode fazer bem a ela contar. Clara parece estar em dúvida sobre o que vai fazer e permanece em silêncio. Digo para ela que fique à vontade e divida com o grupo o que quiser e a seu tempo. Clara então revela que, na verdade, ela havia engravidado desse namorado e por isso sua família a havia expulsado de casa. Quando ela foi morar com a tia, conheceu o marido que criou a filha como sua. Embora a filha saiba da história, elas pouco falam sobre o assunto. Clara diz que sempre se sentiu muito errada devido a tudo o que aconteceu.

Lúcia fala da boa mãe que ela era para a filha e que isso é importante, e não o passado. Clara diz que sabe disso, mas sempre se sentiu errada e carregava uma grande culpa pelo acontecido. Conta que seus pais eram muitos rigorosos e não a deixavam namorar e ir a bailes. Aos 15 anos, ela conheceu o pai de sua filha e se apaixonou. Ele tinha 22 anos, começaram a namorar escondido, até que, segundo ela, “[...] por ingenuidade, achando que 
íamos nos casar e sermos felizes para sempre, acabei engravidando". Clara disse que demorou em descobrir a gravidez; era muito mal informada sobre isso, pois a mãe não conversava com ela sobre esses assuntos. Quando ela contou aos pais, em suas palavras, “[...] foi um escândalo, imagine naquela época uma menina de 15 anos engravidar. Meus pais não aceitaram e ficaram com muita vergonha que as pessoas da cidade soubessem e acabei indo morar com uma tia em outra cidade, com a desculpa que a mudança era para que eu pudesse estudar."

Clara conta ainda que a tia a apoiou e a ajudou na gravidez e no parto; quando a filha era ainda bebê, ela conheceu o marido e, tempos depois, se casou com ele. Diz que o marido sempre foi um ótimo pai, que considerava a filha como sua. Alguns anos depois, ela tentou engravidar novamente e não conseguiu. Tereza e Lúcia fazem várias perguntas: “E o pai de sua filha, você o viu novamente? E seus pais, tiveram contato com a neta?" Clara conta que o namorado sumiu quando soube da gravidez e nunca mais o viu. Clara chora ao falar da mágoa que tem dos pais, que nunca aceitaram sua filha, tampouco o que havia acontecido com ela. Teve com eles alguns contatos ocasionais e bastante formais, mas nunca conseguiram tratar do assunto e expor seus sentimentos. Todas nós ficamos sensibilizadas com o relato de Clara. Digo que ela deve ter sentido confiança no grupo para poder contar algo tão delicado e ressalto o quanto é bom poder dividir um segredo que ela traz há tantos anos. Clara concorda e sorri.

Isa pergunta sobre a filha de Clara: "ela não ficou revoltada?" Clara diz que não, porque o marido sempre foi ótimo pai e a filha sofreu muito quando ele morreu. Conta que, assim que a filha cresceu um pouco, começou a contar a história por partes, até que por volta de 12 anos ela já a conhecia por inteiro. Sempre achou a filha bastante equilibrada e conta que ela nunca havia demonstrado vontade de procurar e conhecer o pai. Os anos se passaram e elas raramente falam do assunto. $\mathrm{O}$ genro conhece a história, mas seus netos não. Clara fala que às vezes sente falta de conversar com a filha, mas fica constrangida, e sente como se houvesse uma barreira que as impedisse de falar do assunto. Falo que Clara, ao nos contar a sua história, poderia estar começando a fazer a sua parte para derrubar essa barreira, já que o fato dela aceitar e entrar em contato com a própria história poderia facilitar também as conversas com a filha. Como já estávamos no final da sessão, combinamos que as demais trariam suas fotografias e objetos, que não puderam ser mostrados, em uma próxima vez. 


\section{DÉCIMA TERCEIRA SESSÃO}

"Maçãs e caquis"

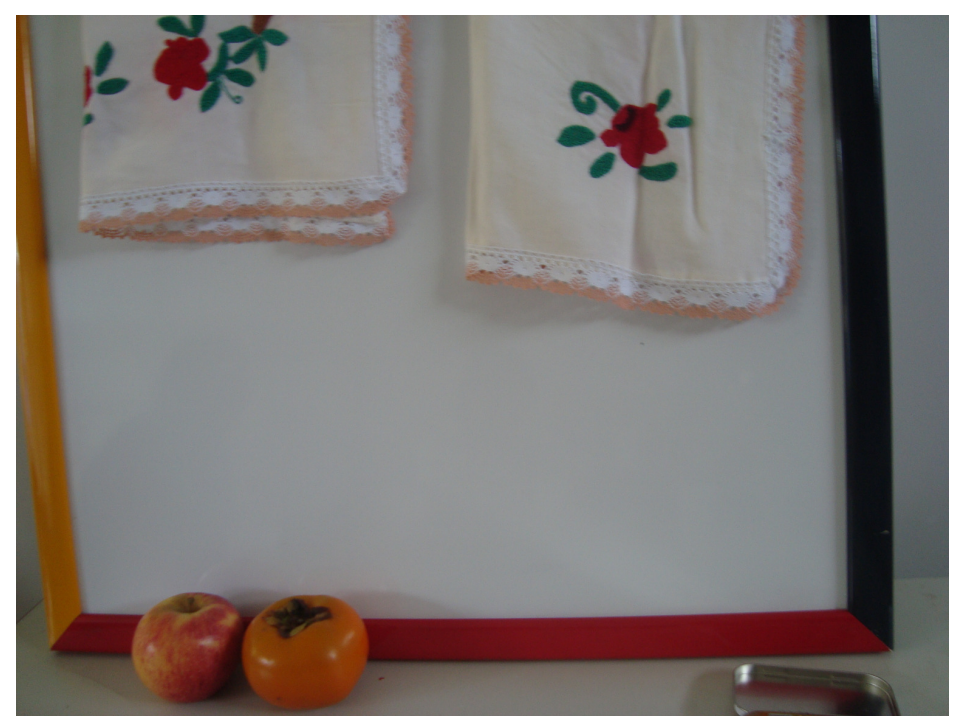

Iniciamos a sessão e Clara apoia uma maçã e um caqui em frente ao quadro magnético. Ela tira as frutas de um pacote maior e diz que é um presente, pois foi muito bom para ela poder falar de seu segredo, sente-se aliviada e também grata. Angélica traz toalhinhas bordadas por ela. Conta que durante a semana conseguiu pegar algumas encomendas de panos de prato e toalhas bordadas a mão, o que a deixou bastante contente. Fala também, bem animada, que conheceu uma senhora que organiza um bazar de dia das mães e a convidou para expor seus trabalhos. Como ainda faltam alguns meses, ela pretende confeccionar várias peças até lá, para participar do bazar. Todas a parabenizam, dizendo que seus trabalhos vão fazer muito sucesso.

Tereza disse que não se sente bem, está muito nervosa e angustiada. Soube que um de seus netos, o mesmo que já havia sido pego pela polícia pichando os muros da cidade, está bebendo muito. Ela disse que procura se controlar, mas não consegue evitar preocupar-se com tudo e com todos. Todas passam a aconselhá-la, dizendo que ela não pode mudar as pessoas e precisa aceitar como cada um é. Tereza chora e explica que tem muito medo de que o nervosismo faça mal para sua saúde; tem medo de que aconteça a ela o mesmo que ocorreu com Bento, um ataque cardíaco. Lúcia diz que ela está tentando melhorar, se cuidar. Ressalto que, na entrevista inicial, antes do nosso trabalho começar, ela havia afirmado não saber se conseguiria vir a todas as sessões, devido à depressão e aos problemas de saúde, e mostro que 
estamos quase no final de nosso trabalho e ela conseguiu vir a quase todas e parece menos ansiosa agora do que no início.

Tereza concorda e diz que está se esforçando para mudar, mas que ainda é difícil não se preocupar tanto, principalmente com os netos em relação à violência dos dias de hoje. Isa diz que ela deve tentar não se preocupar tanto. Fala: “[...] olha o meu caso, meu filho sempre foi ajuizado, nunca me deu trabalho e acabou morrendo tão cedo. A gente não manda em nada, não controla nada. Aproveite que seus filhos e netos estão aqui hoje, o futuro a Deus pertence."

Clara diz que concorda com Isa. Fala que, como mora com a filha, genro e netos, às vezes acha que ela representa uma carga para eles; mas, ao mesmo tempo em que, às vezes, pensa em morar sozinha, também tem receios. Muitas vezes eles opinam sobre a sua vida e ela fica brava, mas sente também que eles gostam muito dela, é sua família, e ela quer também aproveitar o convívio. Acha que está bem de saúde, mas mesmo se cuidando, como ela faz, pode ficar doente e se tornar dependente, sem ter alguém que cuide dela.

Sinto que as preocupações de Clara mobilizam o grupo. Passam a falar do medo que sentem de ficar dependentes, dando trabalho para os outros na velhice. Angélica diz: "Prefiro morrer antes, não quero dar trabalho para ninguém”. Tereza acha que é obrigação dos filhos cuidar dos pais na velhice, e que eles devem fazer isso por gratidão. $\mathrm{O}$ assunto gira em torno desse tema, sobre a capacidade que alguns têm de ser gratos e outros, não. Estamos terminando a sessão e lembro a elas que Clara havia, no início, trazido as frutas e falado do seu sentimento de gratidão. Lúcia fala: “[...] a vida é assim, às vezes ganhamos aqui e perdemos lá, uma coisa pela outra. Quando vim para essa cidade, no começo me senti só perdendo, mas depois vi que, por causa da mudança, ganhei muitos amigos. Acho que faz falta a gente ver as coisas boas que acontecem com a gente, parece que é mais fácil vermos as coisas ruins." 


\section{DÉCIMA QUARTA SESSÃO}

\section{"Saudade dos Amigos"}

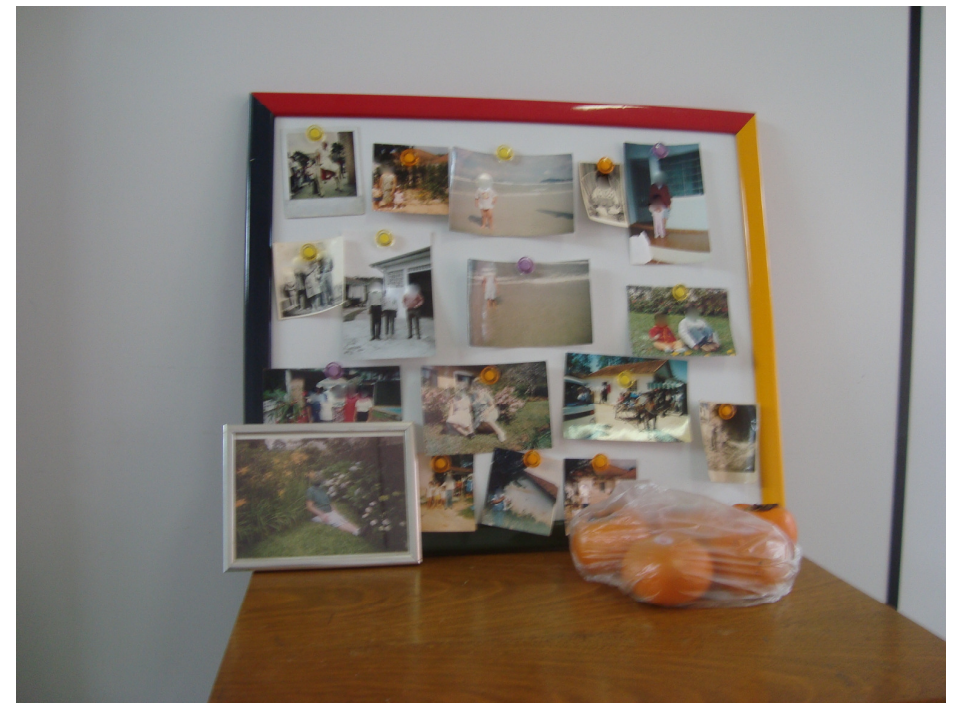

Isa e Tereza não compareceram à sessão. Isa manda um recado que não pode vir devido a uma forte gripe. Clara nos conta que Tereza precisou ir a São Paulo fazer alguns exames. Muitas fotografias são trazidas à Oficina. Chama à atenção a quantidade de crianças retratadas: “[...] é que criança é muito bom”, diz Clara. Clara trouxe novamente caquis. Conta que havia ido à feira naquele dia, achando-os muito bonitos, sentiu vontade de trazê-los para o grupo.

Angélica começa a falar das fotografias que trouxe. Conta-nos que, junto com o marido, foi caseira de uma chácara por muitos anos. Era um local muito bonito, cheio de flores. Ela fala bastante de uma fotografia onde aparecem, ela e a patroa abraçadas, com um jardim ao fundo. Diz que gostava muito dela, que a tratava como uma amiga, com muito respeito e amizade. Conta que, quando precisou de dinheiro para pagar uma dívida, a patroa emprestou a quantia a ela, o que a deixou muito grata. Fala que há muitos anos perderam o contato, mas que sente muitas saudades.

Lúcia mostra uma fotografia onde está cercada de amigas. Conta que são de São Paulo, da época em que era casada e morava na capital. Fala que, após a separação do marido e a mudança, acabou perdendo o contato com muitas delas. Com outras, se encontra raramente e mantém contato somente nas datas comemorativas. Diz que hoje, passado tanto 
tempo, considera que a mágoa sentida com a separação a fez também se afastar de tudo que a lembrasse daquela época, inclusive de suas amigas. Sente saudade delas e acha que deve procurá-las mais. Ainda dentro do mesmo tema, Lúcia se lembra de uma amiga, também frequentadora do Grupo da Terceira Idade, que a acolheu com muita atenção e carinho quando veio morar na cidade, e destaca o quanto isso foi importante para ela. Um tempo depois, essa mesma amiga ficou doente e acabou perdendo a audição. Lúcia disse que pôde, naquela oportunidade, também ajudá-la bastante.

Clara traz muitas fotos dos netos, da filha e do genro. Conta de viagens e de ocasiões festivas. É muito próxima dos netos, que já lhe disseram ser uma avó “muito jovem”. Clara atribui isso ao seu gosto pela ginástica. Ela é frequentadora assídua das aulas de ginástica e caminhada, organizadas pelo Grupo da Teceira Idade, e tem muitos amigos no grupo. O assunto versa sobre as pessoas que conhecem em comum e que também frequentam as atividades da Terceira Idade. Angélica se lembra de uma amiga que tem em comum com Lúcia e Clara. Elas relembram que essa amiga participa todos os anos do concurso "Miss Terceira Idade”, promovido pela Prefeitura local, e que já ganhou algumas vezes o título. Elas falam o quanto a tal amiga é divertida e vaidosa e que, a cada ano, renova as roupas com as quais vai se apresentar no concurso. Elas contam que nos bailes essa amiga é muito disputada e tirada para dançar várias vezes.

Lúcia aponta que, nos bailes que foi, observou que Clara também é bastante convidada a dançar. Elas riem e Clara diz que já notou o mesmo com relação à Lúcia. Lúcia fala: “Eu gosto muito de dançar e aceito os convites, não tem nada demais, mas a... (fala o nome da senhora que participa dos concursos de beleza) é muito namoradeira. Eu não namoro, é só para dançar". Clara fala que pensa do mesmo modo e que, quando vai aos bailes, só quer se divertir um pouco, mas que às vezes tem alguém interessado em namorá-la, mas ela não quer. Em seguida, passam a falar novamente das fotografias e das lembranças por elas despertadas. Ao final da sessão comentam como foi bom lembrar-se de pessoas queridas, de quem muitas vezes acabam se esquecendo, por causa da rotina da vida, ou não dando o devido valor a essas amizades. 


\section{DÉCIMA QUINTA SESSÃO}

"Planos e sonhos"

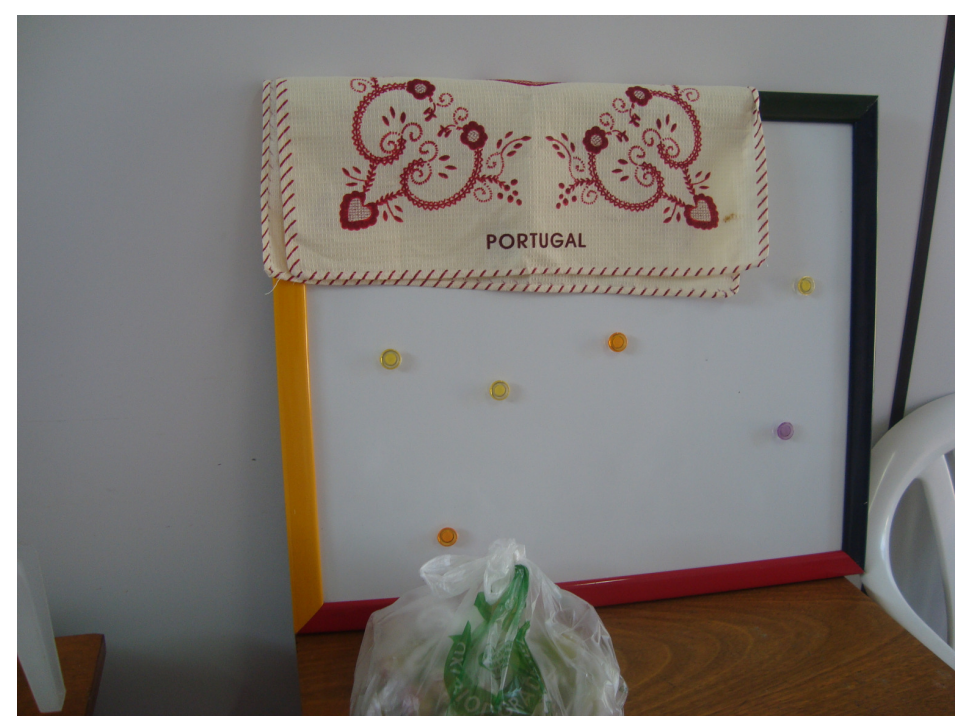

Iniciamos a sessão com todas as participantes presentes. Noto que a maioria não trouxe nenhum material à sessão. Lúcia traz a toalha que veio de Portugal. Clara, mais uma vez, traz frutas de presente e as coloca apoiada sobre a mesa. Comento que a falta do material pode significar o início de uma despedida, pois aquela seria a nossa penúltima sessão.

Lúcia diz que a sessão passada a havia feito pensar bastante. Conta que por ser de família portuguesa, sempre teve o sonho de visitar a terra dos pais e avós, mas nunca havia podido ir. Soube que, depois de sua separação, o ex-marido havia ido com a nova esposa para a Europa, o que lhe trouxe grande mágoa. Lúcia fala que sentia estar na hora de realizar esse sonho. Em breve iria completar 80 anos e não sabia até quando teria saúde suficiente para poder viajar. Ela tinha algumas economias e planejava viajar com uma amiga para Portugal. Todas a apoiam, dizendo que viajar é muito bom e que ela deve realmente ir.

Isa conta que sua nora, viúva de seu filho, fora convidada para fazer um curso em São Paulo com o objetivo de obter um progresso profissional. Como sua família não mora na cidade, Isa se ofereceu para ajudar a tomar conta dos netos na ausência da mãe. Acha que isso vai ser bom, gosta muito das crianças e seu marido também prometeu ajudá-la. Tereza interrompe Isa, dizendo para que ela tome cuidado para as pessoas não abusarem dela, pois isso havia lhe acontecido. Fala que o fato dos filhos "abusarem" da sua boa vontade, pedindo- 
lhe favores ou pedindo que fique, às vezes, com os netos, a aborrece muito. Ela fala que "[...] eles pedem as coisas e depois, quando eu dou a minha opinião, eles dizem que eu me meto demais na vida deles" Isa diz a Tereza que acha que, não haver abuso, depende dela mesmo, de ela saber dizer não quando não tem vontade ou mesmo condição de fazer algo. As demais concordam com Isa.

Angélica diz que o Pastor da igreja, vizinha a sua casa, a procurou, dizendo que irá mudar-se para um local com melhores condições. Ela fica muito feliz com a ideia, pois não consegue ter paz desde o momento em que a igreja começou suas atividades. Fala que quer ter mais sossego para fazer seu artesanato, e que todas as noites tem reservado um tempo especial para essa atividade. Lúcia conta que em breve terão um curso de "biscuit" como atividade do Grupo da Terceira Idade e Angélica diz que vai participar. Pensam também em reivindicar a volta das aulas de teatro, atividade da qual gostavam muito. Clara fala que tem muita vontade de aprender a usar o computador. Seus netos já tentaram ensiná-la, mas ela gostaria de fazer um curso. Combina com Lúcia para conversarem com a assistente social e pedir um curso de informática.

Tereza fala que está ansiosa pela volta de um de seus filhos da Bahia, pois ele deve lhe trazer notícias dos irmãos e sobrinhos. Conta que, quando alguém da família chega de lá, é sempre uma festa, pois trazem muitos presentes, a maior parte comida tipica, e que todos se reúnem para experimentá-las. Ela nos conta também, que as coisas na sua família parecem mais calmas, com menos brigas e discussões. Fala que quando ouviu Lúcia falar de sua viagem para Portugal, sentiu muita vontade também de fazer uma viagem, quem sabe para a Bahia. Sempre havia achado muito difícil, principalmente devido a seus problemas de saúde, mas que agora começava a achar que poderá ser possível.

Ao final da sessão, destaco que, nesse encontro, muitas puderam falar de planos e objetivos, e esse era um jeito de podermos nos despedir de um processo que chegava ao final, à medida que podiamos pensar e nos entusiasmar com novos projetos. Conversamos sobre o final do processo e como algumas sentiam que seria difícil se despedir do grupo. 


\section{DÉCIMA SEXTA SESSÃO}

\section{"Despedida"}

$\mathrm{Na}$ última sessão ninguém trouxe fotografia ou objeto. Combinaram entre elas e trouxeram refrigerantes, alguns salgados e doces para uma festa de despedidas do grupo. Todas estavam bastante agitadas e falantes.

Elas falaram sobre a participação no grupo e relembramos, olhando o álbum de fotografias que retratava as sessões da Oficina, os momentos pelos quais havíamos passado, inclusive da morte de Bento. Cada uma das participantes se expressou como alguém que de algum modo sentia-se diferente de quando havia iniciado o processo. Clara agradeceu a todas e disse que sentia que as demais seriam amigas para a vida inteira. Relembrou como foi importante contar sobre o seu passado e ressaltou que se sentia mais leve e contente. Disse também que havia sido muito bom para ela ver que todos tinham seus problemas e que não precisava ter vergonha de ter os dela e nem de ficar às vezes triste ou mesmo chorar.

Isa disse ter gostado muito de participar do grupo e sentia que poder ter falado do filho e trazido fotografias e objetos para a Oficina a havia ajudado a não sofrer tanto. A família havia sentido diferença em seu comportamento. Ela ainda ficava triste e chorava quando se lembrava do filho, mas com uma frequência menor. Sentia que a vida continuava e que ela tinha coisas boas para consolá-la: o filho, os netos e seu marido que também precisavam de atenção. Conta que seu filho falecido possuía uma motocicleta da qual gostava muito e que estava guardada em sua casa. Toda vez que Isa olhava para ela sofria muito, pois se lembrava do filho, mas não queria se desfazer daquele veículo. Na semana passada, ela havia pensado melhor, conversou com a nora e resolveram vendê-lo. Conta que a sensação foi boa, de alívio.

Angélica disse que, como Isa, também chorava ao se lembrar do marido, mas menos que antes. Sentia-se diferente, segundo ela, um pouco mais corajosa na vida. Já não se sentia tão culpada quando não conseguia fazer algo a que tinha se proposto. Acha importante pensar na sua saúde e quer tentar um tratamento novo para a artrose nos joelhos. Um dos médicos do Posto de Saúde recomendou-lhe que buscasse um tratamento no Hospital das Clínicas e ela havia pedido a um dos filhos para acompanhá-la. Voltou a falar com entusiasmo do seu artesanato e das perspectivas de aprendizado de novas técnicas e do comércio de seus produtos. Fala que gostou muito de trazer suas coisas para o grupo, tanto objetos pessoais 
como o artesanato, e o fato do grupo valorizar seus trabalhos tinha-lhe feito muito bem. Acrescenta que sempre tinha se sentido, segundo ela, "menos que as outras pessoas, porque não sabia ler e escrever". Não havia decidido ainda se realmente ia tentar se alfabetizar, conforme sugestão do grupo, "mas que hoje sentia que sabia muitas outras coisas."

Tereza fala também da mudança que sente. Acha que está um pouco mais calma e menos desanimada e que sua família havia comentado que ela estava também, segundo ela, menos mandona e briguenta. Acha que está conseguindo aceitar melhor a vida dos filhos e dos netos e que ela não pode interferir em tudo. Não sabe se vai continuar assim depois do encerramento do nosso trabalho. Está insegura com o término do grupo. Ressalto que elas podem buscar futuramente um atendimento individual, ou mesmo em grupo, com um psicólogo da cidade ou de um local próximo. Mostro também a possibilidade, considerada a distância, de um atendimento psicológico no serviço APOIAR da USP, em São Paulo. Elas me perguntam sobre a possibilidade de uma continuidade com frequência mensal da Oficina e fico de conversar com a assistente social do Grupo da Terceira Idade sobre esse assunto.

Por fim, Lúcia também agradece e fala que participar do grupo a fez se conhecer um pouco melhor. Disse que gostou muito de poder trazer as fotos e os objetos à sessão, pois acha que isso a fez participar e sentir mais as coisas, tanto suas quanto de outras pessoas também. Conta que no início do trabalho ficou com receio de, segundo ela, revirar suas mágoas, mas que no final do processo sentia-se muito bem e acha que o tipo de trabalho com fotografias e objetos contribuiu para isso.

Ao final da sessão senti que todas nós estavamos emocionadas. Agradeci a participação e o empenho que demonstraram em participar da Oficina e combinamos os encontros que finalizariam o nosso processo de forma individual. 


\section{CAPÍTULO V - COMPREENDENDO O PROCESSO}

Este capítulo é dedicado a reflexões e considerações acerca do processo vivenciado pelos integrantes do grupo durante as sessões da Oficina Psicoterapêutica de Cartas, Fotografias e Lembranças. Nessa reflexão buscamos discutir nossas observações, dialogando com os autores que fundamentam a introdução teórica deste estudo, segundo os aportes da teoria Psicanalítica, especialmente aqueles inspirados no pensamento winnicottiano e no conceito de campo psicológico desenvolvido por Bleger (1963/1984). Em um primeiro momento apresentamos como o processo da oficina Psicoterapêutica pôde ser compreendido, considerando os campos psicológicos observados em cada sessão e a transição entre esses campos presentes no movimento entre elas.

Posteriormente, fazemos considerações sobre o processo, da perspectiva da recordação e do conceito de transicionalidade. Finalizamos o capítulo ampliando a compreensão clínica com a visão dos próprios participantes, levando em conta os resultados da reaplicação das escalas e da síntese dos relatos ocorridos nas entrevistas individuais que finalizaram essa etapa da pesquisa.

\section{1 - O Processo da Oficina Psicoterapêutica: Identificação e Transição entre Campos Psicológicos}

No capítulo anterior, os resumos das sessões da Oficina Psicoterapêutica de Cartas, Fotografias e Lembranças receberam títulos, expressos por frases ou palavras, com o objetivo de identificar, a partir dessa leitura, o principal campo psicológico presente em cada encontro. Apoiados nos conceitos desenvolvidos por Bleger (1963/1984), que aponta para o caráter dinâmico e ao mesmo tempo singular dos campos psicológicos que aparecem implicados nas condutas, outros campos também podem ser identificados nas sessões. A partir dessa ideia é possível analisar a transição entre os campos que ocorrem em cada sessão e no processo psicoterapêutico como um todo, evidenciando assim possíveis transformações desses campos psicológicos (AIELLO-VAISBERG, 2008; CAMPS, 2009). 
No começo da primeira sessão, vimos que os participantes, ainda bastante reservados e parecendo pouco à vontade na situação grupal, não trouxeram cartas, fotografias ou objetos. A ansiedade gerada pela expectativa em relação à oficina e como ela aconteceria, expressa por muitos deles nas entrevistas ou nas histórias contadas a partir do SAT, parece ter contribuído para esse momento. Podemos identificar, nesse início, um campo psicológico que denominamos Apresentação, por refletir as colocações breves, mais superficiais, e pontuadas por períodos de silêncio dos participantes.

A transição para o campo que recebeu o nome de Grupo da Terceira Idade ocorreu à medida que a conversa dos participantes, ainda de caráter mais impessoal, deu destaque, e versou por um período mais longo, às atividades que frequentavam nesse Grupo, do qual foram convidados para participar do processo da Oficina. Pudemos observar, a partir desse campo, o sentimento de surpresa dos participantes, pois, mesmo frequentando as atividades do Grupo, eles não se conheciam bem, o que contribuiria para se sentirem mais à vontade ao se expor.

Em um momento posterior, ao relembrarmos aos participantes o enquadre proposto na Oficina, buscamos oferecer-lhes o holding (WINNICOTT, 1960/1983) necessário para que pudessem se colocar com mais segurança. Ao retomarmos o convite inicial para que trouxessem cartas, fotografias ou objetos ou, ainda, participassem contando suas lembranças em sessões, onde o sigilo seria respeitado, consideramos que a noção de enquadre foi utilizada de modo mais estratégico do que técnico e, portanto, conforme pontua Aiello-Vaisberg (2004), permanecendo mais fiel ao conceito proposto por Bleger, (1963/1984).

Após esse momento, pudemos observar a mudança para o campo psicológico que consideramos central na sessão, denominado Tem coisas na vida que a gente não conta para ninguém. Esse campo foi organizado a partir da fala da participante Lúcia, que pareceu ter representado os sentimentos do grupo ao expressar os principais conflitos inconscientes dos participantes. Ela expôs sobre a dificuldade de falar sobre si, principalmente a respeito de temas que não são comumente partilhados; ou, ainda como Tereza reforçou, dizendo que nesse grupo é mais difícil falar adotando uma posição ativa, se comparada com o papel de alunos que desempenham nos Grupos da Terceira Idade.

Essa questão nos remete para o fato de que, de modo geral, o trabalho dos Grupos de Terceira Idade é de grande valia e oferece muitos benefícios aos participantes. No entanto, muitas vezes, uma visão assistencialista pode contribuir, em alguns casos, para que o idoso 
assuma uma postura mais passiva e frágil diante da vida (Gil, 2005). Nesse sentido, um trabalho com outro tipo de proposta, como é o caso da Oficina Psicoterapêutica, traz a possibilidade de uma participação que reforça a postura mais ativa e autônoma do idoso, à medida que ele pode, como aponta Goldfarb (2006), ter a sua palavra e vontade validados a partir da escuta de seus desejos.

Notamos que, quando esse campo psicológico se tornou consciente ao grupo, alguns participantes puderam começar a falar de si mesmos, entrando em contato com seus sentimentos, como ocorreu com Angélica ao falar do marido. Outros, como Tereza, demonstraram aspectos mais defensivos e permaneceram falando de assuntos gerais, não se colocando ainda de forma individualizada na Oficina.

O campo psicológico identificado no final da primeira sessão apontou para a possibilidade dos participantes trazerem para a Oficina suas vivências acompanhadas dos sentimentos despertados por elas. Em consequência, observamos que, no segundo encontro, houve a transição para um novo campo onde a maioria dos participantes passou a falar de suas lembranças a partir das fotografias e dos objetos trazidos à sessão, como é a proposta do enquadre. Os relatos foram principalmente relacionados a perdas que algumas das participantes tiveram, como é o caso de Isa e Angélica que falaram sobre o sofrimento decorrente da morte do filho e do marido, respectivamente.

Nesse ponto, ao analisarmos a forma de recordar de que Isa e Angélica se utilizaram em seus relatos, principalmente no primeiro encontro da Oficina, recorremos à teoria desenvolvida por Salvarezza (2003). Segundo os pressupostos do autor, ambas apresentam, no início da participação da Oficina, uma maneira que o autor considera nostálgica de recordar, pois enfatizam em seus relatos, principalmente, os elementos ligados às perdas que sofreram. A sintomatologia depressiva que apresentaram pode expressar o fracasso dos mecanismos de defesa frente aos sentimentos gerados por essas vivências. É importante notar que Salvarezza (2003), ao desenvolver sua teoria, fala de perdas que se referem àquelas que são diretamente relacionadas ao processo de envelhecimento. No caso das participantes, além dessas perdas relativas à velhice, que foram também abordadas por elas no decorrer do processo da Oficina, nessa segunda sessão, tanto Isa como Angélica, relataram a grande dor que sentiam em consequência de perdas de filhos e pessoas queridas.

Ainda na segunda sessão, pudemos identificar, a partir da fala de Angélica, uma relação entre a importância do material trazido à sessão e o apoio que as lembranças 
representaram ao se recordar de fatos difíceis da vida. A ideia de que as fotografias e os objetos trazidos à sessão poderiam representar o alívio para o sofrimento que alguns dos participantes sentiam, assinalou a configuração de um novo campo psicológico nomeado $O$ apoio para o sofrimento.

As vivências que emergiram desse campo, no que diz respeito à relação com o material trazido à sessão, podem ser compreendidas baseadas na ideia de objetos de self (SAFRA, 2004). Assim, com relação aos objetos de Angélica - o terço e o sabonete embalado - podemos dizer que eles, além de refletir o seu modo de ser, de início podiam ser considerados como subjetivos, mas passaram a adquirir significado ao fazer parte da sua vida. Além dos objetos trazidos por Angélica, esses conceitos podem ser aplicados também ao de Lúcia - pano bordado - que, nesse caso, retrata não só o presente mas também o desejo de ter conhecido Portugal. Vale ainda destacar que, embora Tereza não tenha trazido nenhum material à sessão, a configuração do campo psicológico predominante nesse encontro favoreceu a sua manifestação de modo que ela contou suas vivências ao grupo, entrando assim em contato com os sentimentos advindos de suas lembranças.

$\mathrm{Na}$ terceira sessão, o campo psicológico - identificado a partir da relação do material que os participantes trazem à Oficina com as lembranças e os sentimentos despertados pareceu ganhar ainda mais força. Podemos falar, assim, de um campo que designamos Vivendo a proposta terapêutica, criado a partir da conduta dos participantes, que trouxeram à sessão um grande número de fotografias e objetos, e relataram suas vivências a partir das lembranças despertadas. Assim, foi possível observar que esse campo, além de conter vivências relativas à apresentação do material, também propiciou aos participantes fazerem observações justamente a partir das vivências da Oficina. Assim, Tereza relatou a dificuldade em resolver o que trazer à sessão, e Clara associou suas ideias sobre qual material trazer aos encontros com o grupo.

As vivências relativas a esse campo possibilitaram, ainda na terceira sessão, um novo campo psicológico relacionado ao anterior, mas com características mais específicas, que identificamos como Presente e Passado. Estimuladas pelas lembranças advindas das fotografias e objetos, o novo campo incluiu as questões sobre as relações entre o presente e o passado. Como exemplo, podemos citar o relato de Lúcia sobre a lembrança da traição de seu marido e a fala sobre a importância do que vivera no passado para a constituição de sua vida 
presente. Do mesmo modo, podemos pensar também na colocação de Isa, que gostaria de poder lembrar-se do filho sem a carga do sofrimento que sentia.

A relação entre os objetos e à temporalidade é abordada por Machado et al (2003), da perspectiva do conceito de objetos dramáticos, que destacam nesses objetos a capacidade de constelar no presente experiências emocionais significativas do passado. Como exemplo de objetos dramáticos que foram trazidos a essa sessão, podemos pensar tanto nas fotografias do filho falecido, trazidas por Isa, como na latinha que guardava o dinheiro do passado, esquecido por Angélica, ou mesmo nas fotografias e objetos apresentados por Lúcia, no início da Oficina.

O campo emocional que diz respeito a aspectos do Presente e Passado pode ser compreendido também a partir dos conceitos de Bleger (1963/1984). Para o autor, um campo ambiental ocupado na época presente sempre estará vinculado a aspectos da história do indivíduo, tanto com relação ao passado como em relação a perspectivas futuras. Essas observações se evidenciam na proposta terapêutica da Oficina, já que a materialidade utilizada - fotografias e objetos - nesse tipo de enquadre parece favorecer a formação de um campo psicológico que permite o estabelecimento dessas relações e, consequentemente, também a criação de novos campos. Assim, o que foi vivenciado no passado pode ser lembrado na época presente e, ao ser ressignificado, pode gerar mudanças futuras.

No quarto encontro do grupo, identificamos uma mudança no comportamento dos participantes. Ao contrário da terceira sessão, quando foram trazidos muitos objetos e fotografias pela grande maioria das pessoas, essa sessão foi quase que exclusivamente ocupada pelas várias fotografias de Bento, único participante do sexo masculino do grupo e que pouco havia se manifestado nos encontros anteriores. Essa modificação evidenciou um novo campo psicológico, ao qual chamamos de A história de Bento. Ele se organizou quase que exclusivamente a partir das recordações despertadas em Bento pelas fotografias que o retratavam em várias fases de sua vida. Dessa forma, o seu relato ao grupo pareceu organizar sua história.

Quando contou suas recordações ao grupo, ele falou de acontecimentos do passado, e dos sentimentos que teve na época, e também os relacionou com fatos e sentimentos do presente. Com base nessa ideia, podemos considerar que um novo campo psicológico se configurou a partir do campo anterior, ao qual denominamos Engolir sapos. Esse campo se estruturou a partir do relato das vivências de Bento, que falou sobre a postura mais passiva 
que assumiu frente a situações onde considerou que deveria ter se manifestado, ou ainda, conforme suas palavras, sobre "os sapos" que acreditou ter engolido na vida. Ele relacionou esse comportamento aos problemas no coração que enfrentava na época da Oficina, e mencionou sua disposição em querer mudar sua atitude. Essa temática pareceu mobilizar o grupo até o final da sessão, pois outros participantes também falaram, externando seus conflitos relacionados a engolir ou não os "sapos" em suas vidas.

$\mathrm{Na}$ quinta sessão, Bento trouxe também muitas fotografias e, como no encontro anterior, predominou o seu relato. Ele contou ao grupo as lembranças mais relacionadas às vivências com a esposa e com os filhos na época presente. Assim, podemos dizer que o campo psicológico ainda se organizava a partir dos relatos das vivências da História de Bento. No decorrer da Oficina, ele passou cada vez mais a falar sobre o seu comportamento e os sentimentos que identificava na família a partir desses. Bento contou, por exemplo, sobre o seu modo de ser, mais fechado, e as consequentes queixas da esposa e dos filhos. Aos poucos, pudemos perceber que ele foi se implicando nas questões que trouxe até o momento no qual enfatizou que gostaria de mudar o seu comportamento. Podemos pensar que esse momento da sessão favoreceu a criação de um novo campo psicológico que chamamos de Mudanças.

Auxiliado pelo holding (WINNICOTT, 1960/1983) do grupo, Bento se surpreendeu com o fato de poder falar tanto sobre si e do consequente bem estar que sentiu. É possível observar que a presença dos objetos dramáticos (MACHADO et al, 2003), representados pelas fotografias por ele trazidas e as recordações que surgiram a partir delas favoreceu o estabelecimento de uma ligação entre o que foi vivenciado no passado e a época presente. Devemos destacar que nesse processo, o grande catalisador foi o fato de que essas lembranças puderam ser compartilhadas com o grupo, fornecendo o holding necessário para o estabelecimento da comunicação emocional.

Considerando esse mesmo campo psicológico, outros participantes falaram sobre suas experiências relacionadas a mudanças em suas vidas e à necessidade de adaptações a uma nova realidade, como, por exemplo, o caso de Angélica quando se referiu ao uso da bengala para se locomover. Em outro momento da mesma sessão, Bento contou sobre a eminência de sua cirurgia cardíaca, o que lhe trouxe muitas apreensões que foram partilhadas com o grupo. Os participantes demonstraram, assim, uma grande mobilização, pois todos buscaram animálo e acolhê-lo. 
Ao pensarmos no processo vivênciado por Bento nessas últimas duas sessões, recorremos aos aportes teóricos de Salvarezza (2003), quando ele relaciona os conflitos advindos de questões relacionadas ao envelhecimento com o aumento do que denominou de interioridade no indivíduo idoso. Para o autor é justamente essa condição que permite o recordar por meio de reminiscências, que por sua vez estão relacionadas a aspectos mais saudáveis, principalmente no que diz respeito à integração egoica. Nesse sentido, pode-se notar que o enquadre da Oficina Psicoterapêutica possibilitou a Bento conseguir entrar em contato com seus sentimentos e conflitos em um momento onde vivenciava, não só questões relacionadas diretamente ao envelhecimento, como aponta Salvarezza (2003), mas principalmente no que dizia respeito à sua saúde e integridade física no presente.

Assim, Bento denotou esse aumento da interioridade à medida que pôde falar de si e se surpreender com mudanças no seu comportamento, pois ele, que sempre havia sido tão fechado, conforme relatou, conseguiu expor ao grupo fatos de sua vida e seus sentimentos. Foi possível observar que Bento, ao entrar em contato com suas reminiscências, sentiu-se mais integrado e próximo de si mesmo, o que gerou, segundo as próprias palavras, um grande bem-estar.

O período que compreendeu o espaço de tempo entre a quinta e a sexta sessão foi marcado pelo falecimento repentino de Bento, vítima de um enfarte. Ao iniciarmos a sexta sessão, não sabíamos como o grupo iria encarar tal perda e como poderia ocorrer a continuidade do processo da Oficina. Nomeamos Há uma cadeira vazia aqui, o campo psicológico estabelecido nesse encontro a partir do próprio gesto concreto do grupo, que justificou a cadeira vazia colocada a mais na sala como uma homenagem a Bento; ou ainda nas palavras de Lúcia, como uma forma de dizer que ele seria sempre lembrado como fazendo parte daquele grupo.

A configuração desse campo expressou a forma como o grupo vivenciou a perda de Bento. Desse modo, no início, a ênfase maior foi colocada no fato ocorrido e no modo como se deu, tema do início da sessão. Em seguida, experenciamos um momento de emoção, quando, por meio da cadeira vazia, foi feita a homenagem a Bento, garantindo assim simbolicamente que ele, ao ter um lugar no grupo, faria parte das lembranças de todos no processo vivido. Para aquela sessão não foram trazidas fotografias ou objetos; contudo várias participantes expressaram seus sentimentos a partir de experiências pessoais de morte e 
perdas, demonstrando que, embora bastante sensibilizadas, foram capazes de dar continuidade ao processo da Oficina.

No início da sessão o grupo demonstrou muita dor e necessidade de falar e contar o fato. Precisavam ser ouvidas e partilhar entre elas, e com a psicoterapeuta, um acontecimento tão difícil e mobilizador. Evidenciou-se que o setting estabelecido no processo psicoterapêutico da Oficina forneceu o holding necessário à criação de um ambiente de confiança, capaz de acolher o gesto espontâneo (WINNICOTT, 1960/ 1983) dos participantes. Consequentemente, foi possível aos participantes que começassem a falar sobre as vivências de Bento na Oficina e assim lhe prestaram a homenagem por meio da cadeira vazia. Esse conceito é utilizado para designar uma das formas de expressão do self verdadeiro, relacionado a experiências vividas no início do desenvolvimento emocional. O gesto espontâneo, segundo Winnicott (1960/1983), está vinculado a experiências de integração e criatividade denotando que a homenagem a Bento e o reasseguramento de seu lugar na história do grupo foram vivenciados pelo grupo como um momento de integração.

No sétimo encontro da Oficina, poucas fotografias e objetos foram trazidos pelas participantes. O campo psicológico que emergiu na sessão anterior, devido à morte de Bento, trouxe ressonâncias a esse encontro, criando um novo campo que podemos nomear Luto. Assim, a quantidade reduzida de material refletia essa vivência, o que fez o quadro magnético se apresentar diferente das sessões anteriores. Clara e Angélica percebendo esse vazio no quadro buscaram fotografias que tinham disponíveis em suas carteiras, tentando dar mais vida àquele momento.

A fala inicial de Angélica, quando relatou as recordações despertadas pelos objetos que trouxe, revelou um sentimento de mágoa frente a fatos ocorridos em sua vida. Esse sentimento pareceu mobilizar o grupo, e as demais participantes passaram a falar sobre o modo como cada uma reagia diante de situações que as magoavam na vida, tendo como pano de fundo a mágoa vivida ali por todos com a falta de Bento. Identificamos assim um novo campo psicológico que intitulamos Mágoas: uns choram e outros não. O grupo mostrou que diante de mágoas cada um manifestava sentimentos diferentes: tristeza ou raiva. Alguns choravam e outros não. Nesse momento, o grupo falava de forma consciente das mágoas, sendo que Isa trouxe as lembranças e o luto pelo filho falecido. Dessa forma, o campo denominado Luto, que remetia à perda tão brusca e recente de Bento, esteve presente todo o tempo durante o encontro. 
A oitava sessão da Oficina trouxe lembranças associadas às festas do final do ano e, desse modo, emergiram de um campo emocional relativo ao Natal. Nesse encontro foram trazidos somente objetos. Como parte desse campo psicológico, identificamos um movimento do grupo que sinalizava tanto uma preparação para as festas de final de ano, como também para a interrupção das sessões durante duas semanas em função dos feriados. Observamos, assim, que as participantes vivenciaram ganhos com as festas e perda pela interrupção dos encontros. Algumas das participantes deram retorno de como estavam se sentindo nesse momento (metade do processo) e em relação às dificuldades que haviam trazido ao grupo anteriormente. É importante também notar que, por vezes, a conduta de Angélica se diferenciava das demais participantes do grupo, pois, mesmo nesses momentos, ela permanecia trazendo objetos e compartilhando com o grupo suas lembranças.

Na nona sessão, no retorno da interrupção acima mencionada, compareceram somente Angélica e Clara, pois as demais estavam viajando. As vivências relativas ao campo psicológico identificado na sessão anterior pareceram influenciar esse encontro, pois notamos, a partir de suas falas, uma preocupação em garantir a continuidade do processo da Oficina. Essas questões contribuíram para a estruturação de um novo campo psicológico que nomeamos Estamos aqui de volta. Nesse sentido, Clara ressaltou em suas verbalizações a importância de estarmos de volta ao grupo, o quanto valorizava sua participação, e demonstrou a esperança de que o grupo, com a presença de todos os participantes, estivesse reunido em breve.

A décima sessão foi marcada pela presença de todas as participantes, que trouxeram muitas fotografias e objetos ao encontro. Dessa forma, o campo emocional identificado na sessão anterior, de certa forma se reatualizou também nesse encontro, pois o grupo se mostrou bastante participativo e empenhado em mostrar suas fotografias e seus objetos e compartilhar suas lembranças. Demonstravam assim que estávamos dando continuidade ao processo da Oficina e que de fato estavam todas de volta.

Observamos nesse encontro, na fala da maioria das participantes, o relato de algumas mudanças que elas vinham percebendo. Isa sentia-se melhor da dor pela perda do filho; Lúcia sentiu-se acolhida pela irmã; e Tereza, apesar de ter se sentido fisicamente mal no natal, conseguiu melhorar e aproveitar os feriados fazendo uma viagem. Nesse contexto, evidenciou-se a satisfação de Angélica ao ter os seus trabalhos de artesanato elogiados pelo grupo, o que a fez se sentir encorajada a expor, nessa sessão, o fato de não saber ler nem 
escrever, do qual sentia vergonha. Clara, por sua vez, também se mostrou contente quando contou ao grupo que conseguiu reafirmar seu desejo diante da família quando não quis viajar.

Observa-se, nesse momento do processo, o potencial de transformação e a criação do equilíbrio entre ganhos e perdas nessas mulheres, que se mostraram associados à ideia atual de um envelhecimento bem sucedido, em que o idoso "pode fazer e ser o melhor possível com os recursos de que se dispõe" (NERI, 2006, p.32). As vivências das participantes demonstraram que elas estavam de fato fazendo o melhor possível com os recursos de que dispunham, como ficou evidenciado na fala de Lúcia ao contar ter se sentido acolhida pela família, apesar de suas mágoas; e na de Isa, que aproveitou a viagem para conviver com seus irmãos e assim se sentir mais reconfortada.

Ao considerar essas vivências das participantes, podemos identificar nesse encontro um campo psicológico expresso como Um grande mosaico. Essa designação foi inspirada na fala de Lúcia que, no final da sessão, ao observar o quadro comparou-o a um mosaico composto pelo material trazido pelas participantes, onde cada fragmento as simbolizava e se compunha num todo harmônico. A fala de Lúcia sintetizava o intenso sentimento de integração que permeava esse encontro. Winnicott (1962/1983) se refere a esse estado como integração do Self, o qual possibilitou vivências observadas pelas participantes: sentiram-se mais próximas de si mesmas de modo real e criativo.

Na décima primeira sessão, foi vivenciado um momento especial a partir da boneca de Angélica e as lembranças despertadas, que causaram grande mobilização no grupo. Todas as participantes se mostraram surpresas com a boneca e interessadas no relato de Angélica, o que ocupou quase todo o tempo da Oficina. Constatamos nesse encontro a presença de um campo psicológico nomeado Uma boneca muito especial. O campo anterior com seu sentido integrador pareceu ter propiciado que esse outro emergisse, observando-se um movimento muito rico entre um campo e outro, ao longo dos encontros. Assim, esse movimento propiciou que Angélica trouxesse um objeto à sessão investido de grande importância em sua vida, como também permitiu ao grupo acolhê-lo, compartilhando com ela tanto o objeto concreto todas queriam tocar na boneca - como também suas lembranças.

No campo psicológico criado nesse encontro, observamos os sentimentos de surpresa despertados diante da boneca e do relato de Angélica. Winnicott (1968/1994) refere-se ao Jogo do Rabisco e sua utilização na Consulta Terapêutica apontando a necessidade do psicoterapeuta criar um setting capaz de oferecer o holding necessário para que o paciente 
possa se surpreender com ideias e sentimentos que não estavam integrados até então à sua personalidade. Refletindo sobre os acontecimentos da sessão, a boneca de Angélica e todo o seu vital significado, identificado como objeto dramático (MACHADO et al, 2003), favoreceu a todas que pudessem ser experenciados tais sentimentos de surpresa. $\mathrm{O}$ ambiente acolhedor que ofereceu holding a esses sentimentos propiciaram movimentos de maior integração de novas ideias e sentimentos em todas as participantes do grupo.

A transição entre os campos psicológicos observados entre a décima primeira e a décima segunda sessão, reafirmou o movimento de integração que vinha ocorrendo e contribuiu para a formação de um novo campo. Assim, no décimo segundo encontro da Oficina, identificamos um campo psicológico a partir das vivências de Clara e suas ressonâncias no grupo, ao qual nomeamos como Quero contar um segredo. Nessa sessão, Clara, auxiliada pelas recordações despertadas pelas fotografias que trouxe, decidiu contar ao grupo que havia engravidado aos 15 anos de idade e, em consequência, seus pais a haviam mandado embora de casa; e que a filha, fruto desse relacionamento, fora criada pelo marido como se fosse, de fato, sua filha natural.

Clara, ao contar a história, entrou em contato com esses sentimentos que mantinha escondidos, emocionando-se bastante, o que não havia acontecido até então. Aqui também se evidenciou a integração de Clara, e das demais participantes, uma vez que ela foi capaz de integrar uma situação que há muito ocultava, agora vivida de uma nova forma, com confiança, tendo assim um espaço no grupo e nela também.

$\mathrm{Na}$ décima terceira sessão, o campo psicológico designado como Maçãs e Caquis apontou para vivências relacionadas à gratidão e à percepção de mudanças nas vidas das participantes, além da capacidade de considerar os aspectos positivos nas situações que enfrentavam na vida. Clara trouxe frutas de presente para o grupo, comportamento que manteve até o final do processo da Oficina. Ela associou o presente com a gratidão e o alívio por ter se sentido acolhida pelo grupo, no tocante ao seu segredo, e a forma como ela agora podia encarar e viver essa experiência de vida.

Ainda nessa sessão, Angélica falou da satisfação em expor seus trabalhos de artesanato em um bazar, assim como se sentiu animada para aumentar sua produção. É importante notar que esses acontecimentos na vida de Angélica evidenciaram, além de outros aspectos, uma mudança com relação a sua inserção social. Assim, a questão do analfabetisno, trazida por Angélica nas entrevistas iniciais e mais tarde no próprio processo da Oficina como 
razão de constrangimento, não a impediu de valorizar a sua habilidade de fazer artesanato e mesmo comercializar seus produtos. Dessa forma, o trabalho psicoterapêutico permitiu à Angélica resgatar potencialidades independentemente de sua idade, como apontam Neri (2006) e Chapot (2009). Ela pôde assim, ao utilizar recursos disponíveis, no caso o artesanato, alcançar uma nova condição de inclusão social o que, consequentemente, contribuiu para a valorização e elevação de sua autoestima e bem-estar. Angélica tambem pôde vivenciar um aspecto de sua vida - o analfabetismo - de uma nova forma, que se revelou mais integrada.

O movimento observado em algumas participantes, quanto a mudanças e vivências positivas, não ocorreu com todas da mesma forma e no mesmo ritmo. Como qualquer idade, a velhice também não se constutui em uma categoria homogênea, sendo necessário considerar as diferenças individuais (MINAYO, 2006). Tereza voltou a falar de suas preocupações e do medo de sofrer um ataque cardíaco tal qual acontecera a Bento. Essas preocupações e situações de doença eram frequentes em sua história de vida. Tereza pôde apresentar, no entanto, alguns momentos nos quais conseguiu lidar melhor com seus sintomas, sentindo-se menos ansiosa, como relatado por ela na sessão após o Natal.

A partir da décima quarta sessão identificamos um campo psicológico que, de modo mais amplo, apontou para o encerramento do processo terapêutico, que nomeamos Despedida. Percebemos também nesse encontro um campo emocional que trouxe referências à Saudade dos Amigos. A partir das fotografias e das lembranças, Clara, Angélica e Lúcia, falaram do sentimento de saudade de amigos, e recordações relacionadas a eles. Ao mesmo tempo, quando as participantes ressaltaram o sentimento de saudade, podemos pensar que elas também estavam entrando em contato, de modo não consciente, com esse campo de Despedida que dizia respeito à finalização do processo que se aproximava.

$\mathrm{Na}$ décima quinta sessão, percebemos um campo psicológico expresso por Planos $e$ Sonhos, para a qual as participantes trouxeram muitas vivências relacionadas a objetivos e projetos que gostariam de realizar em suas vidas, tornando, portanto, mais consciente o campo emocional criado a partir do processo de despedida do grupo. Lúcia falou sobre o seu desejo de viajar; assim como Tereza, Clara gostaria de aprender a usar o computador; e Isa contou sobre o projeto de ajudar a nora a tomar conta dos netos. Angélica falou sobre seus planos com relação ao artesanato e também sobre a vontade de aprender coisas novas. A partir dessa sessão, notamos que os objetivos mencionados pelas participantes se caracterizaram, em sua maioria, por levar em conta aspectos da realidade individual, pressupondo desse modo a 
utilização dos recursos de que cada uma dispõe em suas próprias vidas. Evidencia-se, assim, a perspectiva de um envelhecimento saudável ao considerar a possibilidade de mudanças nessa fase da vida (TEIXEIRA ; NERI, 2008).

É interessante observar que as participantes não trouxeram fotografias a esse encontro e os poucos objetos presentes - as frutas, de Clara e o pano, de Lúcia - já haviam sido trazidos em outras sessões, denotando assim um processo natural de pouco investimento em face do término do processo. Ao final dessa sessão pudemos conversar sobre as dificuldades de encerrar o grupo, o que sem dúvida contribuiu para o campo psicológico relacionado à Despedida estar mais consciente a todas no nosso décimo, e último, encontro. Nessa sessão, cada participante fez referências a como se sentiam no presente, situando-se também com relação às queixas e questões trazidas ao grupo no início do nosso trabalho. Elas falaram ainda sobre o significado do processo psicoterapêutico e das mudanças individuais que perceberam ao finalizar os nossos encontros.

Nesse campo relativo à Despedida, além das vivências que mencionamos, pudemos também perceber o sentimento de satisfação por terem concluído o processo psicoterapêutico, o que resultou na festa de despedida organizada pelo grupo. Ao mesmo tempo, lidamos com as dúvidas e inseguranças pertinentes ao término do processo e com a manifestação do desejo das participantes de continuidade das sessões da Oficina.

No final do processo, a partir do campo Saudade dos Amigos e da saudade que anteviam sentir do grupo e da psicoterapeuta na despedida que se impunha, e também do campo de Planos e Sonhos, observamos um movimento entre os campos emocionais que refletiu uma experiência mutativa, ocorrendo assim um campo de Ganhos para todos os participantes da Oficina. 


\section{2 - Compreensão das Vivências Emocionais na Proposta Terapêutica: Recordação e Transicionalidade}

Apresentamos a Oficina de Cartas, fotografias e Lembranças como proposta psicoterapêutica dirigida ao grupo que fez parte desse estudo e observamos que os participantes aceitaram o convite e trouxeram muitas fotografias e objetos às 16 sessões realizadas. A partir dessas materialidades concretas, os participantes falaram sobre suas recordações e lembranças advindas de um passado distante ou mais próximo, compartilhando assim, no presente, vivências emocionais significativas e concluindo com projetos para o futuro.

Com o objetivo de aprofundar a compreensão dessas vivências refletiremos a partir dos conceitos que embasam a proposta dessa forma de enquadre clínico diferenciado. Nesse sentido, a reflexão teve como elementos principais os conceitos de recordação, esta considerada como um elemento central na teoria psicanalítica e de transicionalidade, desenvolvido por Winnicott (1951/2000). A ideia de que a materialidade utilizada na Oficina favoreceu o recordar dos participantes pode ser analisada, inicialmente, da perspectiva das fotografias e dos objetos que foram trazidos à sessão.

Inspirados nos conceitos da psicanálise winnicottianna, a materialidade utilizada nesse tipo de enquadre deve apresentar, segundo Aiello-Vaisberg (2004), um caráter considerado formlessness $^{15}$, o que, de modo similar a um estado de não integração, (WINNICOTT, 1945/2000) favoreceu o movimento dos participantes relacionados ao criar/encontrar, possibilitando vivências mais criativas e saudáveis que objetivam a superação de dissociações. Na Oficina, as fotografias e os objetos trazidos às sessões apresentaram uma amorfia relativa e despertaram a recordação das lembranças em um ambiente terapêutico auxiliado pelo holding (1962/1983) do grupo, contribuindo assim para estados de maior integração de Self (1960/1983) como apontamos no item anterior.

As fotografias e os objetos apresentados pelos participantes do grupo podem ser designados como objetos de self (SAFRA, 1999; 2004), pois de algum modo refletiam o

\footnotetext{
15 Segundo o New Oxford American Dictionary, a palavra formlessness refere-se a algo sem forma ou estrutura claramente definida.
} 
modo de ser daquele indivíduo e passaram a adquirir significado ao fazer parte de suas vidas. Esses objetos podem ser considerados também como transicionais (WINNICOTT, 1951/2000) à medida que se localizam em uma área intermediária de experiência, entre o que é objetivamente percebido (o objeto em si) e o que é subjetivo (o significado do objeto). $\mathrm{Na}$ Oficina, os objetos trazidos e as fotografias ilustram esse caráter. Assim, a folha de uma árvore e o ticket de uma lanchonete, que despertaram lembranças sobre um determinado passeio realizado por Lúcia, até a boneca trazida por Angélica, cujas lembranças permeavam grande parte de sua história de vida, são objetos que têm qualidades que vão além dos aspectos subjetivos de cada um, mas se constituem no Espaço Potencial (WINNICOTT, 1967/1975) criado na Oficina, em uma experiência que pôde ser compartilhada com o grupo (SAFRA, 2009).

No enquadre da Oficina, os objetos ocuparam essa área intermediária e adquiriram assim o caráter transicional pela ligação que se estabeleceu entre o passado e o presente, por meio da recordação que esses objetos despertaram. Ao mesmo tempo, a recordação que ocorreu no enquadre da Oficina pôde ocupar "um lugar de descanso" frente à tarefa de manter as realidades internas e externas ao mesmo tempo separadas e inter-relacionadas (WINNICOTT, 1951/2000). Os objetos trazidos têm essa potencialidade, pois favorecem a separação e a inter-relação entre a realidade externa (concreta) e interna.

A possibilidade de Clara revelar seu segredo sobre a gravidez mostra como, de fato, um ambiente de confiança auxiliado pelo holding (WINNICOTT, 1962/1983) fornecido pela psicoterapeuta e pelo grupo é capaz de propiciar experiências como essa, de crescimento pessoal e desenvolvimento de potencialidades. Clara, a partir das lembranças despertadas pelas fotografias, pôde falar sobre esses acontecimentos difíceis de sua vida e compartilhar com o grupo as experiências e sentimentos advindos deles, tanto apoiada pelo holding do grupo que proporcionou um ambiente sustentador, como também pelas fotografias trazidas, que possibilitaram o apoio necessário para essa "volta ao passado" e posterior retorno ao presente.

Após esse encontro, Clara demonstrou algumas mudanças, passando a validar mais o seu desejo perante a família e trazendo, assim, vivências a partir das quais ela parecia menos submissa e mais próxima de si mesma. Desde essa sessão, ela começou a trazer frutas para o grupo, o que ocorreu até o final do processo. Essas frutas foram apresentadas investidas do 
sentimento, verbalizado por Clara, de gratidão e alívio por ter compartilhado seu segredo em um ambiente que se mostrou sustentador para essa experiência.

Entre outros exemplos, identificamos esse processo também com Isa, quando falava da dor que sentia decorrente da morte do filho. No contexto da Oficina, as fotografias foram elementos importantes, pois percebíamos que a apresentação desse material acompanhada do relato parecia ter um efeito estruturante e organizador, aliviando a angústia de Isa. Os efeitos do holding (WINNICOTT, 1962/1983), fornecido de modo específico pelas fotografias, puderam ser também observados na quarta sessão, quando Bento organizou seu relato a partir desses objetos transicionais, sentindo-se mais confiante para falar sobre sua vida.

Na Oficina, o holding (1962/1983) fornecido pelo grupo e pelos objetos, ao propiciar um ambiente facilitador, permitiu a cada participante vivenciar suas experiências em um tempo próprio. Assim, nas sessões, há um início mais hesitante e um momento posterior em que os participantes se mostravam mais envolvidos. Depois encerravam os relatos e partilhavam com os demais suas vivências. Em seguida, dispunham-se a acompanhar o processo vivenciado por outros participantes, quando a sessão era encerrada e os objetos devolvidos a eles. Configura-se assim no sentido que Winnicott traz (1941/2000) como uma experiência completa, ao descrever o Jogo da Espátula.

Green (2007) tece algumas considerações sobre a transicionalidade dos objetos. Embora esse autor tenha desenvolvido seus conceitos psicanalíticos, baseados em um modelo pulsional, de modo diferente de Winnicott, que parte de uma matriz relacional (GREENBERG; MITCHEL, 1994), Green (2007) considera que o objeto transicional tem o significado do simbolismo no tempo. Ele utilizou a figura de uma viagem para falar da percepção, no caso do bebê, entre o subjetivo e o objetivamente percebido e considera que o objeto transicional é o que pode ser percebido desta viagem. Dessa forma, consideramos que os objetos transicionais trazidos à Oficina possuem essa característica que o autor atribui à medida que permitem o recordar, estabelecendo assim a ligação entre tempos distintos.

Green (2008) coloca que o objetivo do tratamento psicanalítico deve possibilitar a relação entre o passado e a experiência de análise, referindo-se ao processo transferencial. Assim, observamos que os objetos transicionais fazem parte da relação transferencial que se estabeleceu no grupo, uma vez que se referem tanto ao passado quanto às situações presentes na Oficina. 
A apresentação das fotografias e dos objetos em cada sessão pode ser vista como um elemento facilitador do brincar, inspirado no paradigma do Jogo do Rabisco (WINNICOTT, 1968/1994). Para o autor, a psicoterapia é considerada uma forma especializada de brincar (1971/1975) que ocorre na sobreposição entre as áreas de brincar do paciente e do Psicoterapeuta. Sob essa ótica, o convite para que os participantes trouxessem o material à sessão da Oficina pode ser compreendido como um primeiro rabisco, ao qual cada um respondeu de uma maneira singular: escolhendo o material que queriam trazer ou ainda não apresentando fotografias ou objetos à sessão, preferindo relatar suas lembranças sem a intermediação dessa materialidade.

Fundamental na proposta dessa Oficina é que a partir da dinâmica descrita, o grupo pôde utilizar o Espaço Potencial (WINNICOTT, 1967/1975) criado para recordar, de forma singular, suas lembranças. Assim, estabeleceu-se um modo de comunicação em que os participantes, com o auxílio dos rabiscos fornecidos pela Psicoterapeuta, puderam descobrir algo por eles próprios em um movimento espontâneo e criativo, que valorizou a singularidade e a subjetividade de cada um.

Consideramos também que, além do sentido da transicionalidade, tais objetos podem ser compreendidos como objetos dramáticos (MACHADO et al, 2003). Tais objetos possuem assim uma função dramática, pois refletem a história de vida de cada um, tendo um sentido que ultrapassa o aspecto representacional, como se vê em Bleger (1963/1984), que se baseia em Politzer (1928/1975).

Além da função atribuída aos objetos, é ressaltado também que essa característica transicional, que permite a ligação entre passado e presente, é possibilitada pelo fato das experiências poderem ser compartilhadas do ponto de vista emocional com o grupo. No enquadre da Oficina vivenciado com esse grupo, percebemos que houve trocas afetivas entre os participantes durante as sessões, as quais colaboraram tanto para o relato das lembranças quanto para suas elaborações. Observamos que as participantes deram um novo sentido ao passado, ressignificando o presente e abrindo-se para novas perspectivas no futuro.

Nesse ponto, é importante ressaltar que a fotografia, ao ser analisada da ótica da psicanálise, guarda algumas características específicas (BENJAMIN, 1940/1994; FRAYZEPEREIRA, 2005) que também observamos nos objetos. Assim, o fascínio que Frayze-Pereira (2005) atribui à fotografia, e que prescinde de explicações, foi também vivenciado pelos 
participantes, principalmente com relação a determinados objetos, como a boneca trazida por Angélica que causou grande fascínio em todos.

Podemos compreender a semelhança mencionada entre as fotografias e os objetos por meio de sua utilização no contexto da Oficina. Nesse sentido, devemos lembrar que é o fato de ocorrer a integração dos objetos trazidos com os relatos despertados pelas recordações dos participantes que colaborou para a sustenção do encontro, abrindo assim a possibilidade para a troca de experiências emocionais e elaboração delas (MACHADO et al, 2003). Nessa perspectiva, podemos compreender melhor o processo vivenciado por Isa que, ao falar das recordações despertadas pelas fotografias do filho falecido, pareceu ter vivenciado de forma concreta o sentimento de dor, que Frayze-Pereira (2005) menciona, relacionado à morte, mas pôde também, por meio de seus relatos, encontrar certo alívio para a dor que sentia.

Aprofundando a discussão sobre a relevância das lembranças e da recordação com o uso de objetos transicionais, podemos considerar ainda algumas reflexões. Para tanto, trazemos conceitos da Psicanálise Relacional (STOLOROV, 2002), em especial o de memória emocional proposto por Orange (1995). A autora o empregava para a compreensão dos aspectos transferenciais da psicoterapia individual e se mostra relevante nesse processo. A memória emocional pode ser compreendida como uma forma de recordação baseada no passado relacional. Para Orange (1995), os fenômenos transicionais são considerados como expressão da própria memória relacional e, nesse sentido, de uma forma não representacional. Da mesma forma, as recordações despertadas por meio dos objetos compreendidos como transicionais ocorrem, no processo aqui descrito, a partir das vivências dos participantes e não da interpretação dos seus significados, evidenciando assim a memória emocional despertada em todos os encontros.

Observamos durante as sessões da Oficina que os participantes, muitas vezes, ao se recordarem de suas lembranças, não conseguiam expressar somente através das palavras o real significado de determinada experiência, sendo de extrema valia a presença dos objetos e das fotografias nas sessões. Como ilustração dessa ideia, referimos que, se Angélica tivesse contado a sua história sem a presença concreta da boneca, somente seria possível captar uma parte da experiência, pois, como pontua Orange (1995), há muitas vezes na linguagem uma incompletude.

Nessa proposta terapêutica é mais valorizado o que o paciente quer saber de si do que ele não sabe (ORANGE, 1995). Freud (1937/1990) compara o trabalho do analista ao do 
arqueólogo, uma vez que o trabalho do analista consiste em reconstruir, a partir de lembranças e das associações do paciente, os conteúdos de seu passado que foram esquecidos. $\mathrm{Na}$ Oficina aqui descrita também se observou um sentido que vincula o relato das lembranças a uma experiência de integração (ou reconstrução como assinala Freud) de aspectos do passado que podem ser ressignificados em relação a vivências presentes.

Também, é importante destacar que o modo de intervenção fundamental, no tipo de enquadre que propomos, é o holding (WINNICOTT, 1962/1983) que favorece movimentos no sentido da integração pessoal. Esse tipo de intervenção não tem um caráter interpretativo, mas pressupõe que as vivências presentes na situação terapêutica se farão acompanhar naturalmente pela articulação simbólica. (AIELLO-VAISBERG ; MACHADO, 2003).

Ainda sob a perspectiva do holding (WINNICOTT, 1962/1983) oferecido aos participantes, é fundamental a disponibilidade emocional do Psicoterapeuta, que auxilia a dispor as fotografias e os objetos no quadro magnético e oferece uma presença atenta e interessada em ouvi-los falar sobre suas recordações. Do mesmo modo, é importante ressaltar que essa forma de intervenção não se relaciona somente à apresentação da materialidade na Oficina, mas se mantém em todo processo com respeito aos aspectos individuais de cada participante.

O enquadre propõe que os participantes tragam fotografias ou objetos às sessões conforme desejem ou então que possam falar de suas lembranças sem a necessidade de trazer algo. Tereza, por exemplo, trouxe pouco material às sessões e pôde se beneficiar vivenciando o processo terapêutico em um ritmo próprio. Essa sustentação do acontecer clínico também se mostrou necessária em sessões como a que ocorreu posteriormente à morte de Bento ou nas sessões finais do processo da Oficina.

Nesse contexto, é relevante o holding (WINNICOTT, 1962/1983) oferecido aos participantes pelo próprio grupo. A partir do sentimento de confiança e incentivo advindo de alguns, todos puderam relatar suas vivências em um ambiente sustentador, o que contribuiu para a transformação dos campos psicológicos (BLEGER, 1963/1984). Nos primeiros encontros da Oficina, em que fotografias e objetos foram trazidos e os participantes puderam fazer seus relatos, muitos carregados de grande dor e sofrimento. Esse momento inicial da Oficina pode ter contribuído para que Bento no quarto e no quinto encontros, a despeito do seu jeito reservado de ser, pudesse se beneficiar ao falar de suas lembranças e assim 
ressignificar aspectos importantes de sua história, amparado e estimulado pelas participantes e pela Psicoterapeuta.

A oficina que apresentamos como proposta terapêutica neste estudo foi dirigida a idosos, o que nos conduz também a refletir sobre as relações entre o envelhecimento e as recordações e, de modo especial, como isso ocorreu no processo vivênciado. No entanto, essa proposta, antes de tudo, visou um trabalho com pessoas que, independentemente da idade, apresentavam grande sofrimento emocional. O mundo mental, o inconsciente, não envelhece, porém o envelhecimento pode colocar em evidência, de modo mais intenso, justamente esse drama humano relacionado a perdas e angústias (GIL, 2005).

Durante o processo da oficina todos os participantes, em alguma medida, apresentaram questões relacionadas a perdas decorrentes do envelhecimento, como vemos também em Salvarezza (2003). Assim, entre outras, por exemplo, Bento e Tereza trouxeram vivências vinculadas a doenças e comprometimentos físicos. Angélica, além dessas questões, apresentava grande sofrimento devido à viuvez. Já Lúcia e Clara, por meio de suas lembranças, expressaram medo do abandono e angústias também sobre o lugar que ocupavam na vida de suas famílias. Isa trazia como maior sofrimento as reações à morte do filho. Pudemos perceber que, principalmente Angélica, Isa e Tereza apresentaram uma forma nostálgica de recordar, pois, em especial no início do processo, suas lembranças enfatizavam aspectos relacionados às perdas e aos conflitos ligados às suas questões. Nessa perspectiva, os sintomas depressivos que apresentavam podem ser compreendidos como expressão do fracasso dos mecanismos de defesa frente aos sentimentos de angústia e ansiedade que apresentavam (SALVAREZZA, 2003).

Observamos que cada participante, no decorrer das sesões da Oficina, em função do aumento da interioridade (SALVAREZZA, 2003), teve acesso a uma forma mais saudável de recordar, representada pelo acesso às suas reminiscências. Assim, confirma-se que poder se recordar das lembranças, desse modo, está relacionado a uma atividade mental mais organizada em que são valorizados os ganhos, o que colabora para o aumento da capacidade de lidar com as perdas e com a autoestima dos participantes. Pode-se compreender a melhora dos sintomas depressivos também com base na mudança da forma como os participantes se recordaram de suas lembranças durante o processo da Oficina.

A recordação das lembranças por meio dos objetos e fotografias, em um ambiente terapêutico auxiliado pelo holding (WINNICOTT, 1962/1983) do grupo, contribuiu, no 
processo da Oficina, para estados de maior integração de Self de seus participantes. Ao longo de sua obra Winnicott $(1945 / 2000 ; 1956 / 2000 ; 1962 / 1983)$ estabelece relações importantes entre o recordar e a superação de dissociações que favorecem as vivências de integração de Self. Assim, ao referir-se a forma de ajuda a crianças pequenas que têm pesadelos, ele fala da importância de alguém relembrá-las desses sonhos, pois assim, em suas palavras, "a dissociação perde espaço" (WINNICOTT, 1945/2000, p.226).

De forma análoga, o enquadre oferecido na Oficina, ao permitir esse recordar das lembranças intermediado por objetos e fotografias contribuiu para a superação de estados mais dissociados em direção a vivências mais criativas e saudáveis. Clara, por exemplo, que trouxe seu segredo ao final do processo conseguiu, ao validar seus desejos, alcançar um estado mais integrado em que ela pôde se sentir mais próxima a si mesma.

O enquadre da Oficina possibilitou a formação de um Espaço Potencial (WINNICOTT, 1967/1975) que considera assim tanto a realidade psíquica interna como o mundo real. Winnicott $(1971 / 1975$, p.151) se refere a um lugar para viver, que não pode ser descrito pelo termo externo ou mesmo interno. Observamos que a Oficina pode ser considerada um lugar para recordar, à medida que proporciona um ambiente onde o recordar das lembranças pode ser considerado terapêutico ao favorecer experiência mutativas aos participantes. Nesse sentido, conforme pontua Safra (2009), é justamente essa ideia do Espaço Potencial que contribui para que ocorra a expansão do atendimento clínico, como na Oficina, pois intervenções com enquadres diferenciados, utilizando o método psicanalítico, podem ocorrer em diferentes lugares e contextos. 


\section{3 - A Voz dos Participantes}

Apresentamos, inicialmente, os resultados da reaplicação das Escalas WHOQOLBREF - Inventário de Qualidade de Vida e do BDI - Inventário Beck de Depressão, considerando que são de autorrelato, ou seja, respondidas pelas participantes. Em seguida, realizamos a síntese das entrevistas finais que integram os resultados comparativos das escalas aplicadas antes e depois da Oficina e a avaliação dos participantes sobre o processo que vivenciaram.

\section{1- Resultados das Escalas}

Com o objetivo de obter uma visão geral dos resultados da aplicação das escalas, apresentamos os dados referentes a cada participante ${ }^{16}$ na primeira e na segunda aplicação de cada instrumento.

TABELA 1 - WHOQOL-BREF-INVENTÁRIO DE QUALIDADE DE VIDA

\begin{tabular}{|c|c|c|c|c|c|c|c|c|}
\hline & \multicolumn{4}{|c|}{$\mathbf{1}^{\mathrm{a}}$ Aplicação } & \multicolumn{4}{|c|}{$2^{a}$ Aplicação } \\
\hline & 1 Dom 1 & 1 Dom 2 & 1 Dom 3 & 1 Dom 4 & 1 Dom 1 & 1 Dom 2 & 1 Dom 3 & 1 Dom 4 \\
\hline Sujeitos & Físico & Psicológico & $\begin{array}{c}\text { Rel. } \\
\text { Sociais }\end{array}$ & $\begin{array}{c}\text { Meio } \\
\text { Ambiente }\end{array}$ & Físico & Psicológico & $\begin{array}{c}\text { Rel. } \\
\text { Sociais }\end{array}$ & $\begin{array}{c}\text { Meio } \\
\text { Ambiente }\end{array}$ \\
\hline Angélica & 42,86 & 37,50 & 33,33 & 28,13 & 60,71 & 50,00 & 50,00 & 50,00 \\
\hline Clara & 60,71 & 62,50 & 66,67 & 68,75 & 53,57 & 62,50 & 66,67 & 75,00 \\
\hline Tereza & 35,71 & 45,83 & 58,33 & 43,75 & 39,29 & 45,83 & 58,33 & 50,00 \\
\hline Isa & 46,43 & 37,50 & 25,00 & 46,88 & 53,57 & 66,67 & 66,67 & 71,88 \\
\hline Lúcia & 60,71 & 54,17 & 41,67 & 56,25 & 64,29 & 58,33 & 33,33 & 65,63 \\
\hline
\end{tabular}

${ }^{16}$ Nos dados apresentados nas tabelas não constam os resultados obtidos pelo participante Bento, pois, como já mencionamos durante a apresentação do processo da Oficina, somente foi possível sua participação até a quinta sessão. 


\section{BDI - INVENTÁRIO BECK DE DEPRESSÃO}

\section{TABELA 2 - PONTUAÇÃO DO BDI}

\begin{tabular}{|c|c|c|}
\hline Sujeito & Total BDI 1ªplic. & Total BDI $2^{\mathrm{a}}$ Aplic. \\
\hline Angélica & 21 & 12 \\
\hline Clara & 3 & 3 \\
\hline Tereza & 31 & 18 \\
\hline Isa & 13 & 7 \\
\hline Lúcia & 9 & 4 \\
\hline
\end{tabular}

TABELA 3 - GRAUS DOS SINTOMAS DE DEPRESSÃO

\begin{tabular}{lcc}
\hline Sujeito & Nível BDI 1 $^{\mathbf{a} A p l i c}$. & Nível BDI 2 $^{\mathbf{a}}$ Aplic. \\
\hline Angélica & Moderado & Leve \\
Clara & Mínimo & Mínimo \\
Tereza & Severa & Moderada \\
Isa & Leve & Mínimo \\
Lúcia & Mínimo & Mínimo \\
\hline
\end{tabular}




\section{2- Entrevistas Finais}

\section{ANGÉLICA}

A reaplicação dos inventários evidenciou significativa melhora de Angélica, tanto na qualidade de vida dela, quanto aos sintomas depressivos. Os resultados das escalas indicaram melhora também em todos os domínios avaliados e diminuição dos sintomas de depressão principalmente relacionados ao humor e autoestima.

Durante a entrevista Angélica contou que, muitas vezes, não foi fácil conseguir comparecer aos encontros da Oficina devido à dificuldade em caminhar, pois mora em um bairro afastado da cidade e com as fortes chuvas o acesso havia ficado mais difícil nos últimos tempos. Disse que se esforçou para estar presente, pois gostou de participar do grupo e sentiu que as nossas conversas lhe eram muito boas. Angélica achou que o mais importante para ela foi ter coragem de mostrar seus trabalhos e sentir que todos a elogiavam, estimulando-a a fazer novas coisas e até a comercializar suas peças de artesanato. Antes, ela não dava tanta atenção a isso, pois se sentia desvalorizada pelo fato de não saber ler nem escrever.

Falou também que a morte do marido e tantas tristezas passadas na vida a tinham deixado desanimada e com pouca esperança de as coisas melhorarem. Durante os nossos encontros, percebeu que todos têm problemas e isso, segundo ela, não era nenhuma vergonha. Ainda sente-se magoada quando recebe pouca atenção de alguns filhos e netos, mas acha que deve pensar mais nela mesma e o que pode fazer para melhorar a própria vida. Quer cuidar mais da sua saúde e aceitou retomar o tratamento para a artrose que havia abandonado. Acha que irá conseguir frequentar mais as atividades do grupo da Terceira Idade, pois assim não se sentirá tão sozinha e poderá também aprender coisas novas, principalmente sobre o artesanato de que tanto gosta. Angélica chora ao falar do marido, mas conta que tem se sentido menos triste que anteriormente. Ao final da entrevista ela ressaltou o quanto gostou de poder falar sobre o marido na Oficina e lembrar-se das histórias e dos presentes que havia ganhado dele, em especial a boneca. 


\section{CLARA}

Os resultados que Clara obteve nos inventários ao final do processo reafirmaram, de modo geral, os dados obtidos anteriormente, indicando boa qualidade de vida e ausência de sintomas depressivos. Clara disse que se sentiu muito aliviada depois de contar o fato da gravidez precoce e a saída da casa dos pais. Falou que não havia se dado conta antes do quanto esse segredo representava um peso na sua vida. Não o contava a ninguém por medo do julgamento das pessoas, pois no seu entender considerava algo muito errado o que fizera. Quando contou sua história ao grupo e sentiu que todas se mostraram compreensivas e carinhosas, isso lhe fez muito bem e menos culpada.

Clara falou também que sempre havia procurado fazer as coisas certas na vida e desse modo procurava não contrariar as pessoas, buscando agradar a todos e, segundo ela, não criando problemas para ninguém. Acha que, com as nossas conversas na Oficina, pôde perceber que muitas vezes, ao procurar atender às expectativas das pessoas, acabava se sentindo triste e desvalorizada, embora não admitisse. Ela falou também do quanto foi bom ter conseguido dizer à família que não gostaria de viajar, pois percebeu que, embora a filha e os netos não tenham gostado, no momento da sua recusa, depois da viagem o relacionamento havia voltado ao normal.

Clara disse que tem se preocupado mais com sua saúde e que muitas vezes se angustia em pensar que pode ficar dependente ou inválida, causando assim transtornos aos familiares. Disse ainda que foi bom poder perceber que muitas das participantes do grupo tinham pensamentos semelhantes. Sentiu-se, assim, mais próxima das pessoas, podendo perceber que chorar ou se sentir aflita e ansiosa eram manifestações que muitas delas também tinham e que, nesse sentido, era importante, como haviamos conversado em uma das sessões, poder admitir esses sentimentos em si mesma. Mais ao final, Clara mencionou seu desejo de conversar com a filha sobre os acontecimentos passados e assim conhecer melhor sentimentos dela. Relembrou também a morte de Bento e disse sentir muito que ele não pudesse ter continuado na Oficina, pois achou que ele havia aproveitado bastante. Clara se despediu bastante emocionada, reforçando que gostaria de poder continuar o nosso trabalho. 


\section{TEREZA}

A reaplicação do WHOQOL-BREF em Tereza mostrou resultados semelhantes aos da primeira aplicação, com exceção do domínio físico, que se mostrava mais comprometido anteriormente e cujo resultado, nesse segundo momento, apontou para melhora. A segunda aplicação do BDI indicou melhora acentuada dos sintomas depressivos que, de um grau severo, passou para uma classificação considerada moderada.

$\mathrm{Na}$ entrevista final, Tereza disse que, no início do nosso trabalho, achou que teria dificuldades em se expor diante do grupo e ela, sempre tão falante, sentiu-se insegura e percebeu-se mais quieta nas sessões do que de costume. Com o passar do tempo, passou a confiar mais nas pessoas e sentiu-se mais a vontade. Acha que depois da morte de Bento o grupo ficou mais unido e as pessoas mais amigas e dispostas a escutar mais os problemas que cada um trazia. Disse ter sido também muito difícil para ela lidar com a morte de Bento, pois ela passou a temer, por ter problemas no coração, que o mesmo lhe acontecesse. Quanto ao fato de trazer fotografias e objetos à sessão, disse não ter conseguido muitas coisas, pois segundo ela, escolhia demais e depois não conseguia resolver o que trazer. Acha que no fundo tinha receio de se expor, mas sentiu-se melhor quando foi reforçado que poderia contar suas lembranças sem que fosse necessário trazer algum material.

Tereza disse que as sessões da Oficina a ajudaram a se sentir melhor, mais animada, e que principalmente a família havia comentado que ela parecia menos ansiosa e briguenta. Tereza falou que ainda se preocupa muito com os problemas de saúde, o que a deixa nervosa e ansiosa, mas de forma menos intensa que anteriormente, mesmo porque tem se sentido melhor fisicamente. Ela continua com os tratamentos dos quais necessita, mas acha que está conseguindo benefícios porque toma os remédios e segue as recomendações médicas com mais disciplina que antes. Segundo Tereza, o mais importante, durante o processo da Oficina, foi perceber que ela não podia controlar a vida dos filhos e netos como vinha fazendo até então, pois essa atitude a deixava muito ansiosa e contribuía para a piora de seus sintomas e nesse sentido já observava algumas mudanças.

Ao final, como externado na última sessão da Oficina, Tereza compartilhou de sua insegurança em encerrar o trabalho da Oficina e combinamos que a auxiliaria no encaminhamento para um atendimento psicológico individual. 
O resultado da reaplicação do WHOQOL-BREF apontou para melhora da qualidade de vida de Isa, que se refletiu em todos os domínios avaliados, porém se mostrou mais acentuado com relação ao domínio psicológico. A comparação entre os resultados do BDI apontou também para importante diminuição dos sintomas depressivos que, segundo os critérios da escala, indicaram, após o término do grupo, para a ausência de quadro de depressão.

Isa, conforme já vinha relatando durante as sessões da Oficina, contou que tem se sentido melhor e mais confortada com relação à perda do filho. Ainda chora quase todos os dias, mas sente que esses momentos de tristeza e angústia conseguem ser mais rapidamente substituídos por outros de maior esperança. Sua família sentiu a diferença em seu comportamento e reforçou que deveria continuar fazendo um tratamento psicológico. Isa falou que o fato de poder falar do filho e trazer suas fotografias às sessões havia sido muito importante para ela. Sentiu-se assim mais próxima a ele ao se recordar de várias situações que haviam vivenciado. Isa disse que nos encontros da Oficina se sentia mais livre para poder chorar e demonstrar a sua dor, pois em casa os familiares se mostravam sempre preocupados e, por isso, evitava o máximo possível dar vazão aos sentimentos.

Embora tenha muita saudade do filho, tem conseguido ver as coisas boas que existem em sua vida e, nesse sentido, valorizado cada vez mais o apoio que recebe da família. Sente-se disposta a continuar dando aulas de piano e tentar recuperar o prazer que sentia com essa atividade antes da morte do filho. Quer também ajudar a cuidar dos netos enquanto sua nora se ausentar e acha que vai ser muito bom para que se sinta útil e ajudando a família.

Ao final da entrevista Isa falou que a morte de Bento havia lhe causado muita tristeza, mas ao mesmo tempo conseguia perceber como havia sido bom para ele falar dos problemas e de fatos importantes de sua vida antes de falecer. Disse também que o grupo foi importante para ela perceber que não era a única a sofrer e que outras pessoas, assim como ela, também tinham de aprender a lidar com perdas. 


\section{LÚCIA}

Com relação à reaplicação da escala de qualidade de vida, pudemos observar que Lúcia apresentou melhora nos resultados de todos os domínios, com exceção no das relações sociais. A primeira aplicação havia indicado um resultado abaixo da média e a reaplicação apontou um rebaixamento do resultado relativo a esse domínio. A aplicação da escala Beck demonstrou a diminuição dos sintomas depressivos relatados na etapa inicial do estudo, embora nessa ocasião, conforme os critérios do instrumento, não se configurasse um quadro depressivo.

Lúcia falou que, no início do trabalhou, sentiu, segundo as suas palavras, um preconceito em relação às demais participantes, pois elas talvez não tivessem o mesmo nível cultural que o dela, e isso poderia tornar o grupo não tão proveitoso. No entanto, com o decorrer do processo, percebeu que estava errada, pois todos tinham muitas vivências para compartilhar com o grupo que independiam de estudo ou cultura. Lúcia disse mais, que havia gostado muito de participar do grupo e do fato de trabalharmos com fotografias e objetos, pois assim as recordações dos participantes ficavam mais interessantes, próximas e capazes de serem mais fácilmente compreendidas quando relatadas a partir do material trazido às sessões. Do mesmo modo, achou que as fotografias e os objetos que trouxera à sessão facilitaram a recordação de suas lembranças, contribuindo para falar de si.

Lúcia falou que a perda de Bento contribuiu para que refletisse mais sobre várias questões e relembrou a emoção do grupo manifestada na sessão após a sua morte. Disse que o maior benefício sentido com o trabalho da Oficina foi aceitar mais as coisas na sua vida, o que tem contribuído para não se sintir tão magoada, principalmente com relação a pouca atenção que recebe dos filhos e netos. Lúcia falou também que hoje aceita melhor a separação do marido e a mudança para o interior. Pretende continuar participando bastante das atividades do Grupo da Terceira Idade. Ao final, falou novamente dos seus planos em conhecer Portugal e da esperança de viver ainda muitas coisas boas em sua vida. 


\section{CAPÍTULO VI - SÍNTESE E CONSIDERAÇÕES FINAIS}

Inicialmente apresentamos uma breve síntese, abordando os pontos principais relativos à compreensão do processo vivenciado na Oficina Psicoterapêutica de Cartas, Fotografias e Lembranças. Em seguida, passamos às considerações finais, com conclusões sobre a pesquisa.

Nas entrevistas iniciais e em sessões da Oficina, os participantes trouxeram questões que refletiram muitas vezes experiências relacionadas a perdas e dificuldades que enfrentavam em suas vidas, entre elas: vivências relacionadas à exclusão social, perda da saúde, angústias relativas a prejuízos da capacidade funcional, solidão, morte de entes queridos, e sentimentos de abandono pela família. Esses temas refletem aspectos do envelhecimento observados no mundo contemporâneo e estão relacionados também à visão que a própria sociedade tem do idoso (SALVAREZZA, 2003, 2005; MINAYO, 2006 ; GOLDBARB, 2006 ; FERRIGNO, 2006).

No processo psicoterapêutico, foram identificadas mudanças nos campos psicológicos (BLEGER, 1963/1984) que se estruturaram a partir das vivências dos participantes. Nesse contexto, nos primeiros encontros, os idosos puderam falar sobre suas recordações e lembranças a partir das fotografias e dos objetos que trouxeram às sessões, demonstrando a aderência ao enquadre proposto. Durante o processo da Oficina, o grupo vivênciou um momento delicado com a morte de Bento. Nas sessões seguintes, as participantes demonstraram a capacidade de lidar com essa perda concreta e continuar o processo psicoterapêutico, o que possibilitou a ocorrência de novos campos psicológicos com o relato de mudanças nas vidas das participantes, principalmente ao considerar os aspectos positivos diante de situações que enfrentavam na vida. Nesse sentido, os campos psicológicos passaram a expressar vivências mais integradas que expressaram o desenvolvimento das potencialidades de cada um no grupo.

No que diz respeito ao enquadre utilizado na Oficina Psicoterapêutica, observamos que as fotografias e os objetos facilitaram a recordação das lembranças e a expressão dos aspectos emocionais dos participantes. A partir dos relatos no grupo, notamos que a materialidade favoreceu uma maneira de recordar que não está somente ligada a perdas, mas que de outro modo permitiu aos participantes $\mathrm{o}$ acesso às suas reminiscências (SALVAREZZA, 2003). Assim, durante o processo da Oficina, gradualmente foi se 
estabelecendo um modo de recordar mais saudável, o que se refletiu no aumento da capacidade de valorizar os ganhos e na reafirmação da autoestima dos participantes.

Percebemos que em ambiente terapêutico auxiliado pelo holding (WINNICOTT, 1962/1983; 1951/2000) do grupo ocorreu um campo propício para o compartilhamento de experiências entre os participantes e a elaboração dos conteúdos psíquicos. As fotografias e os objetos foram considerados em seu caráter transicional, à medida que permitiram estabelecer a ligação entre passado e presente, por meio da recordação das lembranças que despertaram.

No Espaço Potencial (WINNICOTT, 1967/1975) criado na Oficina, foi possível então vincular o relato das lembranças dos participantes a uma experiência de integração de aspectos passados que puderam ser ressignificados em relação às vivências presentes, possibilitando assim novas perspectivas para o futuro. Consideramos assim que o enquadre utilizado favoreceu aos participantes do grupo experiências de maior integração de Self ( WINNICOTT, 1960/1983) no sentido da superação de dissociações e recuperação do gesto espontâneo, podendo, dessa forma, agir sobre o mundo de modo mais ativo e criativo.

Ao final do processo da Oficina psicoterapêutica, a observação clínica, os relatos individuais e os resultados descritos pelos instrumentos objetivos que foram utilizados, demonstraram significativa melhora dos sintomas depressivos apresentados inicialmente e, de modo geral, melhora da qualidade de vida de todos os que concluíram a participação no grupo. Entre outros aspectos, pudemos perceber nos participantes maior abertura para o mundo e mais proximidade de si mesmos e de seus sentimentos.

Consideramos ainda que o enquadre diferenciado, realizado de forma breve e em grupo, a exemplo de outros estudos (Gil, 2005, ALTMAN et al, 2008, SCHWARZ, 2008), se mostrou eficaz, facilitando a aderência dos participantes à proposta terapêutica. $\mathrm{O}$ atendimento realizado com idosos em Oficinas Psicoterapêuticas, ao utilizar materialidades mediadoras facilitadoras da expressão emocional, como relatado por autores em trabalhos anteriores (MANNA;AIELLO-VAISBERG, 2006), mostrou-se capaz de atender às necessidades do idoso por cuidados no campo emocional.

O presente estudo foi realizado com o objetivo de apresentar o método psicoterapêutico desenvolvido na Oficina de Cartas, Fotografias e Lembranças como proposta voltada a idosos, em um enquadre grupal, realizado de forma breve. Buscamos assim oferecer uma contribuição na área da Psicologia Clínica e, em especial, à Psicanálise, visto que a 
compreensão clínica da dinâmica dos participantes e do processo vivenciado na Oficina foi desenvolvida a partir dos aportes teóricos de autores desse campo. No entanto, em uma perspectiva mais ampla e de modo semelhante ao observado em estudos anteriores, podemos dizer que nesse processo, além do idoso, encontramos o ser humano em sofrimento na tarefa de lidar, em muitos casos, com experiências que causavam muita dor e angústia (GIL, 2005).

Como conclusão deste estudo, consideramos que os objetivos propostos foram contemplados e a proposta de método psicoterapêutico desenvolvida com esse grupo se mostrou eficaz, considerando a compreensão clínica do processo, a reaplicação dos instrumentos e a visão dos próprios participantes.

Considerando as diferentes etapas da pesquisa, os resultados das avaliações psicológicas e psicodinâmicas realizadas mostraram a importância de avaliar pessoas nessa fase da vida e apontam para a necessidade de pesquisas que possam validar e aprimorar instrumentos que se revelem adequados para utilização com essa população (TARDIVO, 2009).

Com base também na conclusão deste estudo, ressaltamos a importância da adequação desse método psicoterapêutico aos equipamentos de saúde disponibilizados pela rede pública, levando em conta a demanda existente pelo cuidado ao idoso, no que diz respeito à saúde mental, e a necessidade de modelos que representem alternativas que se mostrem eficazes e, ao mesmo tempo, possíveis de ser implementadas.

Finalizamos esse trabalho, reconhecendo a necessidade de novos estudos e pesquisas com a aplicação da proposta da Oficina Psicoterapêutica também em outros contextos e com pessoas de idades diversas. Ao mesmo tempo esperamos, assim, ter cumprido a nossa função de psicólogos clínicos, como destaca Tardivo (2008), em sua acepção mais ampla, que diz respeito à compreensão e intervenção ao ser humano em situação de sofrimento. 


\section{REFERÊNCIAS}

ABRAHAM, K. Teoria psicanalítica da libido - sobre o caráter e o desenvolvimento da libido. Tradução de Christiano Monteiro Oiticica. Rio de janeiro: Imago, 1970. (Trabalho original publicado em 1927).

ABRAM, J. A linguagem de Winnicott: dicionário das palavras e expressões utilizadas por Donald W. Winnicott. Rio de Janeiro: Revinter, 2000.

AIELLO-VAISBERG, T. M. J. Efeitos clínicos da Arteterapia Winnicottiana. In: AIELLOVAISBERG, T. M. J.; AMBROSIO,F. F. (Org.). Cadernos ser e fazer: imaginários coletivos como mundos transicionais. São Paulo: Instituto de Psicologia da Universidade de São Paulo, 2006. p.21-31

Os enquadres clínicos diferenciados e a personalização/realização transicional. In: .; AMBRÓSIO, F. F. (Org.). Cadernos ser e fazer: o brincar. São Paulo: Instituto de Psicologia da Universidade de São Paulo, 2004. p. 6-17.

AIELLO-VAISBERG, T. M. J.; AMBRÓSIO, F. F. Jardins, varandas e quintais: integração, não-integração e transicionalidade. In: FERREIRA, A. M.; FEREEIRA, I. B. M.; MAAZ, M. H. B.; TSCHIRNER, S. A presença de Winnicott no viver criativo: diversidade e interlocução. São Paulo: Zy, 2009. p. 144-149.

AIELLO-VAISBERG, T. M. J.; MACHADO, M. C. L. Pesquisa psicanalítica de imaginários coletivos à luz da teoria dos campos. In: MONZANI, J.; MONZANI, L. R. (Org.). Olhar: Fabio Hermann - uma viagem psicanalítica. São Paulo: Pedro e João Editores, 2008. p. 311324.

Sofrimento humano e estudo da "eficácia terapêutica" de enquadres clínicos diferenciados. In: ___ _ AMBRÓSIO, F. F. (Org.). Cadernos ser e fazer: apresentação e materialidade. São Paulo: Instituto de Psicologia da Universidade de São Paulo, 2003. p.6-35

ALTMAN, M.; YAMAMOTO, K.; SCHWARZ, L.R. TARDIVO, L. S. L. P. C. Atendimento em psicoterapia breve operacionalizada a idosos. In: TARDIVO, L. S. L. P. C.; GIL, C. A. (Org.). APOIAR: novas propostas em Psicologia Clinica. São Paulo: Sarvier, 2008. p.235-247

BARROS, M. S. M.; GIL, C. A.; TARDIVO, L. S. L. P. C. Empleo de encuadres diferenciados em el contexto clínico: el uso de materialidades como mediadoras em el proceso terapêuticode um paciente com depresión grave. In: TRIMBOLI, A. et al. Trauma, história y subjetividad.V Congreso Argentino de Salud Mental. Buenos Aires: Assoc. Argentina de Profesionales de Salud Mental-AASM, 2010. 66-67

BELLAK, M. D. Teste de Apercepção para idosos e adultos-SAT. Tradução de Maria Tereza Antónia Pacheco. Campinas: Psy, 1992. (Trabalho original publicado em 1949)

BENJAMIN, W. Mágia e técnica, arte e política: ensaios sobre literatura e história da cultura. Tradução de Sérgio Paulo Rouanet. São Paulo: Brasiliense, 1994. (Trabalho original publicado em 1940)

BLEGER, J. Psicologia da conduta. Tradução de Emilia de Oliveira Diehl. Porto Alegre: Artes Médicas, 1984. (Trabalho original publicado em 1963). 
BONFIM, T. H. et al. Narrativa de uma Oficina Psicoterapêutica de foto e vídeo com jovens indígenas guarani mby. In: TARDIVO, L. S. L. P. C.; GIL, C. A. (Org.). JORNADA APOIAR: atendimentos clínicos diferenciados: o papel da Psicologia clínica social, 3, 2005, São Paulo. Anais... São Paulo: Instituto de Psicologia da Universidade de São Paulo, 2005. p. 65-76.

BOSI, E. Memória e sociedade: lembrança de velhos. São Paulo: Companhia das Letras, 1994.

2003 .

O tempo vivo da memória: ensaios de psicologia social. São Paulo: Ateliê Editorial,

CAMPS, C.I.C.M. Ser e Fazer na escolha profissional: atendimento diferenciado na clinica winnicottiana. 2009. 204 p. Tese (Doutorado em Psicologia). Instituto de Psicologia da Universidade de São Paulo. São Paulo, 2009.

CHAPOT, S. L. A psicoterapia en la vejez. Un caso clínico. In: Temas de psicogerontologia: investigación, clínica y recursos terapéuticos. Buenos Aires: Librería Akadia Editorial, 2009.

CHAUÍ, M. Convite a filosofia. São Paulo: Ática, 2000.

CUNHA, J. A. Manual da versão em português das escalas Beck. São Paulo: Casa do Psicólogo, 2001.

ERIKSON, E. H. Identidade, juventude e crise. Rio de Janeiro: Zahar, 1972.

FERENCZI, S. Psicanálise III. In: Obras completas. Tradução de Alvares Cabral. São Paulo: Martins Fontes, 1993. cap. 17: Para compreender as psiconeuroses do envelhecimento. p. 145-150. (Trabalho original publicado em 1939)

FERRIGNO, J. C. A identidade do jovem e a identidade do velho: questões contemporâneas. In: Velhices: reflexões contemporâneas. São Paulo: SESC, 2006. p.12-23

FLECK, M.P.A. et al. A avaliação de qualidade de vida: guia para profissionais da saúde. Porto Alegre: Artemed, 2008.

FLECK, M. P. A. Problemas conceituais em qualidade de vida. In: FLECK, M. P. A. et al. A avaliação de qualidade de vida: guia para profissionais da saúde. Porto Alegre: Artemed, 2008. p. 19-28.

FRAYZE-PEREIRA, J. A. Arte, dor: inquietudes entre estética e psicanálise. Cotia, SP: Ateliê Editorial, 2005.

FREUD, S. Construções em análise. In: Moisés e o Monoteísmo. Esboço de Psicanálise e outros trabalhos. 3. ed. Rio de Janeiro: Imago, 1990. v. 23. (Edição Standard Brasileira das Obras Completas de Sigmund Freud. Trabalho original publicado em 1937).

Esboços para a "Comunicação Preliminar" de 1893. In: Publicações prépsicanalíticas e esboços inéditos. 3. ed. Rio de Janeiro: Imago, 1990. v. 1. (Edição Standard Brasileira das Obras Completas de Sigmund Freud. Trabalho original publicado em 1893). 
Lembranças encobridoras. In:

Primeiras publicações psicanalíticas. 3. ed.

Rio de Janeiro: Imago, 1990. v. 3. (Edição Standard Brasileira das Obras Completas de Sigmund Freud Trabalho original publicado em 1899).

FREUD, S. Recordar, repetir e elaborar (novas recomendações sobre a técnica da psicanálise II). In: $\quad$ O caso Schereber: artigos sobre técnicas e outros trabalhos. 3. ed. Rio de Janeiro: Imago, 1990. v. 12. (Edição Standard Brasileira das Obras Completas de Sigmund Freud. Trabalho original publicado em 1914)

Sobre a psicoterapia. 3. ed. Rio de Janeiro: Imago, 1990. v. 7. (Edição Standard Brasileira das Obras Completas de Sigmund Freud. Trabalho original publicado em 1905)

GAVIÃO, A. C. D. Envelhecimento e psicoterapia psicanalítica: um estudo piloto através do método de Rorschach. 1996. 201 p. Dissertação (Mestrado em Psicologia) Instituto de Psicologia da Universidade de São Paulo. São Paulo, 1996.

A passagem do tempo e suas ressonancias íntimas: psicanálise, Rorschach e envelhecimento. São Paulo: Vetor, 2002.

GIL, C. A. Envelhecimento e depressão: da perspectiva psicodiagnóstica ao encontro terapêutico. 2005. 179 p. Dissertação (Mestrado em Psicologia) - Instituto de Psicologia da Universidade de São Paulo. São Paulo, 2005.

GIL, C. A.; AIEllo-VAisberG, T. M. J.; TARDIVO, L. S. L. P. C. A. Oficina psicoterapêutica de cartas, fotografias e lembranças: uma experiência inclusiva. In: HUR, D.et al. In:XVIII CONGRESSO LATINO AMERICANO FLAPAG.,X SIMPÓSIO CEFAS: práticas institucionais na América Latina: Casal, família, grupo e comunidade, 10., 2009, Campinas, Anais... Campinas, 2009. p. 285-285.

Velhice e depressão: a oficina psicoterapêutica de cartas, fotografias e lembranças como intervenção psicoterapêutica grupal. CONGRESSO LUSO BRASILEIRO DE PSICOLOGIA DA SAÚDE: experiência e intervenções, 1., 2009, Faro. Anais... Faro, Portugal: Universidade do Algarve, 2009. p. 1013-1028.

GIL, C. A.; OLIVEIRA, I. T.; TARDIVO, L. S. P. C. O uso do teste de apercepção para idosos (SAT) no diagnóstico compreensivo. In: CONGRESSO LATINO AMERICANO DE RORSCHACH Y OTRAS TÉCNICAS PROYECTIVA: Transformaciones en la subjetividad: Retos a la Psicologia y sus Instrumentos, 7., 2003, Montevideo. Anais... Montevideo, Uruguay, 2003. p. 396-404.

Gil, C. A; PAUlO, M. S. L. L.; TARDIVO, L. S. L. P. C.; TUNG, C. Depressão, raiva e colesterol: possíveis relações. In: CONGRESSO NACIONAL DE RORSCHACH E MÉTODOS PROJETIVOS, 3., 2004, Porto Alegre. Anais... Porto Alegre, 2004.

GIL, C. A. ; TURNA, J.W.T.;AIELLO-VAISBERG, T.M.J. ; TARDIVO, L.S.L.P.C. Oficina psicoterapêutica de cartas, fotografias e lembranças: desafios e esperança no contexto do hospital psiquiátrico. In: TARDIVO, L. S. L. P. C.; GIL, C. A. APOIAR: Novas propostas em psicologia clínica. São Paulo: Sarvier, 2008. p. 347-353.

GOLDFARB, D. C. Velhices fragilizadas: espaços e ações preventivas. In: Velhices: reflexões contemporâneas. São Paulo: SESC, 2006. p.73-85

GREEN, A. Jugar com Winnicott. Buenos Aires: Amorrortu, 2007. 
Orientações para uma psicanálise contemporânea. Tradução de Ana Maria Rocca Rivarola et al. Rio de Janeiro: Imago, 2008.

GREENBERG, J. R.; MITCHELL, S.A. Relações objetais na teoria psicanalítica. Tradução de Emilia de Oliveira Dihel. Porto Alegre: Artes Médicas, 1994.

HERRMANN, F. Pesquisando com o Método Psicanalítico. In: HERRMANN, F.; LOWENKRON T. (Org.). Pesquisando com o método psicanalítico. São Paulo: Casa do Psicólogo, 2004. p.43-83

IBGE-Instituto Brasileiro de Geografia e Estatatística.Sintese de indicadores sociais: uma análise das condições de vida da população brasileira: /IBGE, Coordenação de População e indicadores sociais. Rio de Janeiro, IBGE,2008.

IZQUIERDO, I. A arte de esquecer: cérebro, memoria e esquecimento. Rio de Janeiro: Vieira \& Lent, 2004.

JUNG, C. G. O eи e o inconciente. São Paulo: Vozes, 1979.

KALACHE, A. O mundo envelhece: é imperativo criar um pacto de solidariedade social. Ciência e Saúde Coletiva, Rio de Janeiro, v. 13 n. 4, p. 1107-1111, 2008.

LEBRÃO, M. L.; LAURENTI, R. Saúde, bem estar e envelhecimento: o estudo SABE no Município de São Paulo. Revista Brasileira de Epidemiologia, São Paulo, v. 8, n. 2, p. $127-$ 141, jun. 2005.

LUDKE, M.; ANDRÉ, M. Pesquisa em educação: abordagens qualitativas. São Paulo: EPU, 2006.

MACHADO, M. C. L.; AIELLO-VAISBERG, T. M. J.; GIL, C. A.; TARDIVO, L. S. L. P. C. Oficina psicoterapêutica de cartas, fotografias e lembranças: uma experiência dramática. In: AIELlO-VAISBERG, T. M. J.; AMBROSIO, F. F. (Org.). Cadernos ser e fazer: apresentação e materialidade. São Paulo: Instituto de Psicologia da Universidade de São Paulo, 2003. p. 66-81.

MAMÉDE, M. C. Cartas e retratos: uma clínica em direção a ética. São Paulo: Altamira, 2006.

MANNA, R. E.; AIELLO-VAISBERG, T. M. J. Oficina psicoterapêutica de tapeçaria e outros bordados: bordando a vida ponto-a-ponto. In: AIELLO-VAISBERG T. M. J. AMBROSIO, F. F. (Org.). Cadernos ser e fazer: imaginários coletivos como mundo transicionais. São Paulo: Instituto de Psicologia da Universidade de São Paulo, 2006. p. 95116.

MESSY, J. A pessoa idosa não existe: uma abordagem psicanalítica da velhice. São Paulo: ALEPH, 1999.

MINAYO, M. C. S. Visão antropológica do envelhecimento humano. In: Velhices: reflexões contemporâneas. São Paulo: SESC, 2006.p.47-5

NERI, A. L. O legado de Paul B. Baltes à psicologia do desenvolvimento e do envelhecimento. Temas em Psicologia, Ribeirão Preto, v. 14, n. 1, p. 17-34. 2006. 
Organização das Nações Unidas. Programme on aggeing. Disponível em <http://www.un.org/esa/socdev/ageing/popageing.html>. Acesso em: 25 abr. 2010.

ORANGE, D. M. Emotional understanding: studies in psychoanalytic epistemology. New York: Guillford, 1995.

PY, F. Prefácio. In: PROUST, M. No caminho de Swamm: a sombra das moças em flor. Em busca do tempo perdido. Rio de Janeiro: Ediouro, 2004. v. 1.

POLITZER, G. Critica dos fundamentos da psicologia. Lisboa: Presença, 1975. (Trabalho original publicado em 1928).

REVAULT d'ALLONES, C. Psicologia clínica e procedimento clínico. In: GIAMI, A.; PLAZA, M. (Org.). Os procedimentos clínicos nas ciências humanas: documentos, métodos, problemas.Tradução de Zakie Yazigi Rizkallah e Laila Yazigi Massuh. São Paulo: Casa do Psicólogo, 2004. p.17-34

SAFRA,G. $O$ espaço potencial como método de investigação: estudo da fotografia como recurso clínico. São Paulo: Edições Sobornost, 2009. 1 CD audio MP3. (Palestra proferida em 05 maio 2009).

A face estética do self : teoria e clínica. São Paulo: Unimarco, 1999.

. O manejo do tempo na psicoterapia: a partir da temporalidade de Winnicott. São Paulo: Edições Sobornost, 2009. 1 CD audio MP3. (Palestra proferida em 31 out. 2009).

A po-ética na clínica contemporânea. Aparecida: Idéias e Letras, 2004.

SALVAREZZA, L. La Vezes: una mirada gerontológica actual. Buenos Aires: Paidós, 2005. Psicogeriatria teoria y clinica. Buenos Aires: Paidós, 1993.

SCHWARZ, L. R. EnvelheSer - a busca do sentido da vida na terceira idade: um processo de psicoterapia grupal breve de orientação junguiana. São Paulo: Vetor, 2009.

SILVA, M. E. L. (Coord.). Investigação e psicanálise. Campinas: Papirus, 1993.

SOARES, S. S. G. S. La metáfora nei sentieri della memória. In: ROMANA, F.; ROMANINI, M.; TAIRIELLO, S. (Org.). La Metáfora nella relazione analítica. Atti del IV Incontro ItaloBrasiliano do Psicoanalisi. Milão: Mimesis, 2007.p. 117-123.

STOLOROV, R. D.; ATWOOD, G. E.; ORANGE, D. M. Worlds of experience: interweaving philosophical and clinical dimensions in psychoanalysis. New York: Basic Books, 2002.

TARDIVO, L. S. L. P. C. O adolescente e sofrimento emocional nos dias de hoje. São Paulo: Vetor, 2007.

Aspectos psicodinâmicos em idosos com e sem depressão por meio do Teste de Apercepção Temática para idosos. In: CONGRESSO BRASILEIRO DE RORSCHACH E OUTROS MÉTODOS PROJETIVOS: Avaliação psicológica: Formação, atuação e interfaces, 5., 2009, Campinas. Anais... Campinas: Vetor editora 2009. p. 46. 
TARDIVO, L. S. L. P. C. Qualidade de vida e depressão em idosos de São Paulo: Estudo de validação do Teste Projetivo TAT. Psicologia saúde\&doença.Vv.s. p.154, 2008.

O projeto APOIAR e o Laboratório de Saúde Mental e Psicologia Clínica Social: Relato de uma trajetória. In: TARDIVO, L. S. L. P. C.; GIL, C. A. (Org.). APOIAR: novas propostas em Psicologia clínica. São Paulo: Sarvier, 2008.p.3-8

TARDIVO, L. S. L. P. C.; GIL, C. A. APOIAR: Novas propostas em Psicologia clínica. São Paulo: Sarvier, 2008.

TARDIVO, L. S. L. P. C.; GIL, C. A.; VAGOSTELLO, L.; RABELLO, I. Evaluación proyectiva en adultos mayores: estudio de la precisión y validez del SAT (Senior Aperception Test). In: TRIMBOLI, A. et al. (Org.). Trauma, História y subjetividad. V Congreso Argentino de Salud Mental 2010, Buenos Aires. Anais.... Buenos Aires: Associación Argentina de Salud Mental, 2010. p. 97-99.

TEIXEIRA, I. N. D. O.; NERI, A.L.. Envelhecimento bem-sucedido: uma meta no curso da vida Successful aging: a goal in the course of life. Psicol. USP, São Paulo, v. 19. Acesso em: 20 Ago 2009.

TRENTINI, C. M.; CHACHAMOVICH, E. F. M.; HIRATA, V. N.; FLECK, M. P. A. A percepção de qualidade de vida do idoso avaliada por si próprio e pelo cuidador. Estudos de Psicologia, Natal, v. 11, n. 2, p. 191-197, maio-ago. 2006.

TURATO, E. R. A questão da complementaridade e das diferenças entre métodos quantitativos e qualitativos de pesquisa: uma discussão epistemológica necessária. In: GRUBITS, S.; NORIEGA, J. A. V. Método Qualitativo: epistemologia, complementariedades e campos de aplicação. São Paulo: Vetor, 2004. p.17-51

VERAS, R. Envelhecimento populacional contemporâneo: demandas,desafios e inovações. Revista de Saúde Pública, São Paulo, v. 43, n. 3, p. 548-554, jun. 2009. Disponível em http://www.scielo.br/scielo.php. Acesso em: 02 maio 2010.

VOLPI, A. J. Fotografias e narrativas: presença-ausência, imagens em ação. In: HUR, D. U. et al.XVIII Congresso Latino Americano Flapag. X Simpósio CEFAS: Práticas Institucionais América Latina: Casal, Família,grupo e Comunidade, 2009, Campinas. Anais... Campinas: Federação Latino Americana de Associações de Psicanálise de Grupo - FLAPAG, 2009. p. 63-71.

WINNICOTT, D. W. Contratransferência. In: O ambiente e os processos de maturação. (p.145-151). Porto Alegre: Artes Médicas, 1983. (Trabalho original publicado em 1960).

Desenvolvimento emocional primitivo. In: Da pediatria à psicanálise. Tradução Davi Bogomoletz. Rio de Janeiro: Imago 2000. p. 218-232. (Trabalho original publicado em 1945).

O destino do objeto transicional. WINNICOTT, C.; SHEPHARD, R. (Org.). Explorações psicanalíticas. Tradução de José Octávio de Aguiar Abreu. Porto Alegre: Artes Médicas, 1994, p. 44-48. (Trabalho original publicado em 1959). 
Formas clínicas de transferência. In: Da Pediatria à Psicanálise. Rio de Janeiro: Imago editora p.393-398, 2000. (Trabalho original publicado em 1956).

WINNICOTT, D. W. O jogo do rabisco (Squiggle Game). In: WINNICOTT, C.; SHEPHARD, R. (Org.). Explorações psicanalíticas. Porto Alegre: Artes Médicas, 1994. p. 230-243. (Trabalho original publicado em 1968).

A localização da experiência cultural. In: $O$ brincar e a realidade. Rio de Janeiro: Imago, 1975. p. 133-143 (Trabalho original publicado em 1967).

. O lugar em que vivemos In: O brincar e a realidade. Rio de Janeiro: Imago, 1975. p. 145-152. (Trabalho original publicado em 1971).

O medo do colapso (Breakdow). In: WINNICOTT, C.; SHEPHARD, R. (Org.). Explorações psicanalíticas. Porto Alegre: Artes Médicas, 1994. p. 70-76. (Trabalho original publicado em 1963).

Os objetivos do tratamento psicanalítico. In: O ambiente e os processos de maturação. Porto Alegre: Artes Médicas, 1983. p. 152-155. (Trabalho original publicado em 1962).

Objetos transicionais e fenômenos transicionais. In: Da pediatria à psicanálise. Rio de Janeiro: Imago, 2000. p. 316-331. (Trabalho original publicado em 1951).

A observação de bebês numa situação padronizada. In: . Da pediatria à psicanálise. Tradução Davi Bogomoletz. Rio de Janeiro: Imago 2000. p.112-132 . (Trabalho original publicado em 1941).

O primeiro ano de vida. Concepções modernas do desenvolvimento emocional. In: A família e o desenvolvimento individual. São Paulo: Martins Fontes, 2001. p. 3-20 (Trabalho original publicado em 1958).

Teoria do relacionamento paterno-infantil. In: O ambiente e os processos de maturação: estudos sobre a teoria do desenvolvimento emocional. Tradução de Irineo Constantino S. Ortiz. Porto Alegre: Artes Médicas, 1983. p.38-54 . (Trabalho original publicado em 1960).

O valor da consulta terapêutica. In: WINNICOTT, C.; SHEPHARD, R. (Org.). Explorações psicanalíticas. Porto Alegre: Artes Médicas, 1994. p. 244-248. (Trabalho original publicado em 1965). 
ANEXOS 
ANEXO A

\section{INSTITUTO DE PSICOLOGIA}

\section{DEPARTAMENTO DE PSICOLOGIA CLÍNICA}

\section{TERMO DE CONSENTIMENTO PÓS-INFORMAÇÃO*}

\section{1 - DADOS SOBRE A PESQUISA:}

Essa é um estudo sobre Psicoterapia em grupo dirigida a idosos que será feito para a realização da Tese de Doutorado de Claudia Aranha Gil (CRP 06/32849-4). A Tese será realizada sob a orientação da Professora Livre Docente Leila Salomão de La Plata Cury Tardivo.

Para isso solicitamos sua colaboração na participação do estudo e fazemos os seguintes esclarecimentos:

1- O objetivo do estudo é compreender os efeitos e possíveis benefícios que a Oficina Psicoterapêutica de Cartas, Fotografias e Lembranças pode trazer a quem dela participe, como forma de Psicoterapia em grupo dirigida a idosos e ainda estudar os aspectos emocionais dos participantes. $\mathrm{O}$ estudo tem apenas finalidades acadêmicas e científicas.

2 - As etapas do estudo são as seguintes:

a ) Haverá duas entrevistas iniciais para o conhecimento do estudo, para a assinatura desse Itermo,caso o senhor (a) concorde, e serão aplicados instrumentos psicológicos, de fácil compreensão que exigem respostas simples. O participante poderá se recusar a dar qualquer resposta e solicitar a qualquer momento esclarecimentos.

b) Havendo a concordância do senhor (a), serão realizados 16 encontros, um por semana, com 1h30 de duração para a realização da Oficina Psicoterapêutica de Cartas, Fotografias e Lembranças. Os encontros serão feitos em grupo e os participantes convidados a trazerem cartas, fotografias, objetos ou lembranças de qualquer natureza. Estes objetos serão afixados em um quadro por meio de imãs e a seguir todos poderão falar sobre o que foi trazido pelos participantes. Ao final do encontro a pesquisadora irá fotografar o quadro magnético com os objetos trazidos pelos participantes. Após o encontro os objetos serão devolvidos. O participante poderá participar independente de trazer ou não os objetos.

c) Cada participante será convidado para uma entrevista individual após os 16 encontros, onde serão aplicados novamente alguns dos instrumentos usados no início, com o objetivo de avaliar possíveis mudanças após a psicoterapia. Nesta entrevista o participante será convidado a falar sobre como foi processo terapêutico para ele, e poderá pedir quaisquer esclarecimentos.

3 - Os dados obtidos nesse estudo poderão ser publicados, sendo sempre garantido o anonimato de sua participação. 
4 - Essa participação não constitui nenhum risco a quem aceite o convite.

5 - Com o intuito de preservar a sua intimidade e autodeterminação, o senhor (a) tem o direito de deixar de responder a qualquer pergunta que lhe for formulada, sem ter com isso nenhuma conseqüência ou prejuízo.

6 - O senhor (a) tem o direito de ter o esclarecimento que desejar sobre o estudo sempre que desejar, e poderá deixar de participar a qualquer momento, retirando seu consentimento, sem quaisquer conseqüências ou prejuízos

7- É garantido o sigilo e confidencialidade em toda sua participação.

8 - O senhor (a) poderá entrar em contato com a pesquisadora responsável Claudia Aranha Gil, em qualquer momento, pelo telefone: (11) 9992-0644 - Av. Prof. Mello Moraes, 1721, Cidade Universitária.

\section{2 - AUTORIZAÇÃO}

Após os esclarecimentos dos objetivos e procedimentos do presente estudo, tendo garantida a minha não identificação, manifesto meu consentimento em participar do mesmo, sendo que esse Termo é redigido em duas vias, permanecendo uma em meu poder e outra com a pesquisadora responsável.

Nome do paciente:...

(R.G.)

Assinatura do participante

\section{3 - PESQUISADORA RESPONSÁVEL:}

Claudia Aranha Gil -RG 12.309.533 CRP/06-32849/4

Assinatura:

São Paulo de. de $20 \ldots$.

Endereço do Comitê de Ética em Pesquisa com Seres Humanos do IPUSP: Av Prof. Mello Moraes, 1721, Bloco F, sala 22, Cidade Universitária - São Paulo, SP- fone; (11) 3097-0529.

* Obrigatório para pesquisa científica com seres humanos - Resolução $N^{o} 01$ de 13.06.1988 CNS - Conselho Nacional de Saúde. 


\section{ANEXO B}

\section{UNIVERSIDADE DE SAO PAULO INSTITUTO DE PSICOLOGIA CEPH - COMITE DE ÉTICA EM PESQUTSA COM SERES HUMANOS-}

Registro CEPH No. 2009.061

Título do Projeto: RECORDAÇ̃̃O E TRANSICIONALIDADE: A OFICINA DE CARTAS, FOTOGRAFIAS E LEMBRANÇAS COMO INTERVENÇÃO PSICOTERAPEUTICA GRUPAL COM IDOSOS

Pesquisadora: Cláudia Aranha Gil (Doutoranda)

Orientadora: Profa. Leila Salomão La Plata Cury Tardivo

Departamento/Área de concentração: Departamento de Psicologia Clínica

\section{PARECER}

O projeto volta-se à compreensão do alcance e da eficácia das oficinas de cartas, fotografias e lembranças como enquadre terapeutico diferenciado e, a partir dai, a aprofundar a compreensão das vivencias emocionais de idosos, em especial daquelas relacionadas à recordação e transicionalidade, como são vivenciadas na proposta terapêtica.

Observou-se, no parecer dado, que o termo de consentimento livre e esclarecido juntado em anexo ao projeto de pesquisa não atendia à disciplina do Conselho Nacional de Saúde, apresentando-se demasiadamente técnico, de forma a impedir a compreensẫo do teor e limites da pesquisa pelos seus participantes.

Ante as alteraçóes procedidas pela pesquisadora, que atendem integralmente às recomendaçōes deste Comitê, o parecer é aprovaçâo do projeto. 


\section{ANEXO C}

\section{WHOQOL - ABREVIADO ${ }^{17}$}

Versão em Português

\section{Instruções}

Este questionário é sobre como você se sente a respeito de sua qualidade de vida, saúde e outras áreas de sua vida. Por favor, responda a todas as questões. Se você não tem certeza sobre que resposta dar em uma questão, por favor, escolha entre as alternativas a que lhe parece mais apropriada. Esta, muitas vezes, poderá ser sua primeira escolha. Por favor, tenham em mente seus valores, aspirações, prazeres e preocupações.

Nós estamos perguntando o que você acha de sua vida, tomando como referência as duas últimas semanas.

Por exemplo, pensando nas últimas duas semanas, uma questão poderia ser:

Nada muito pouco médio muito completamente

$\begin{array}{lllll}1 & 2 & 3 & 4 & 5\end{array}$

Você recebe dos outros o apoio de que necessita?

Você deve circular o número que melhor corresponde ao quanto você recebe dos outros o apoio de que necessita nestas últimas duas semanas. Portanto, você deve circular o número 4 se você recebeu "muito" apoio.

17 Será oferecida ao participante a folha de reposta tal como está no manual no site htpp//www.ufrgs.br/psiq/breve/PDF - consulta em 10 de março de 2007

Neste anexo são apenas inseridas as 26 perguntas que compõem o questionário 
Você recebe dos outros o apoio de que necessita?

Você deve circular o número 1 se você não recebeu "nada" de apoio.

Por favor, leia cada questão, veja o que você acha e circule no número e lhe parece a melhor resposta.

1 - Como você avaliaria sua qualidade de vida?

Muito ruim nem ruim nem boa muito boa

$\begin{array}{lllll}1 & 2 & 3 & 4 & 5\end{array}$

2 - Quão satisfeito (a) você está com a sua saúde?

Muito insatisfeito insatisfeito nem satisfeito nem insatisfeito satisfeito muito satisfeito
1
2
3
4
5

As questões seguintes são sobre o quanto você tem sentido algumas coisas nas últimas duas semanas.

$\begin{array}{ccccc}\text { nada } & \text { muito pouco } & \text { mais ou menos } & \text { bastante } & \text { extremamente } \\ 1 & 2 & 3 & 4 & 5\end{array}$

3 - Em que medida você acha que sua dor (física) impede você de fazer o que você precisa? 
4 - O quanto você precisa de algum tratamento médico para levar sua vida diária?

5 - O quanto você aproveita a vida?

6 - Em que medida você acha que a sua vida tem sentido?

7 - O quanto você consegue se concentrar?

8 - Quão seguro(a) você se sente em sua vida diária?

9 - Quão saudável é o seu ambiente físico (clima, barulho, poluição, atrativos)?

As questões seguintes perguntam sobre quão completamente você tem sentido ou é capaz de fazer certas coisas nestas últimas duas semanas.

Nada muito pouco médio muito completamente

$\begin{array}{lllll}1 & 2 & 3 & 4 & 5\end{array}$

10 -Você tem energia suficiente para seu dia-a-dia?

11 - Você é capaz de aceitar sua aparência física?

12 - Você tem dinheiro suficiente para satisfazer suas necessidades?

13 - Quão disponíveis para você estão às informações que precisa no seu dia-a-dia?

14 - Em que medida você tem oportunidades de atividade de lazer?

As questões seguintes perguntam sobre quão bem ou satisfeito você se sentiu a respeito de vários aspectos de sua vida nas últimas duas semanas. 
Muito ruim ruim nem ruim nem bom bom muito

bom

15 - Quão bem você é capaz de se locomover?

Muito insatisfeito insatisfeito nem satisfeito nem insatisfeito satisfeito muito satisfeito

16 Quão satisfeito (a) você está com o seu sono?

17 - Quão satisfeito (a) você está com sua capacidade de desempenhar as atividades do seu dia-a-dia?

18 - Quão satisfeito (a) você está com sua capacidade para o trabalho?

19 - Quão satisfeito (a) você está consigo mesmo?

20 - Quão satisfeito (a) você está com suas relações pessoais (amigos, parentes, conhecidos, colegas)?

21 - Quão satisfeito (a) você está com sua vida sexual?

22 - Quão satisfeito (a) você está com o apoio que você recebe de seus amigos?

23 - Quão satisfeito (a) você está com as condições do local onde mora?

24 Quão satisfeito (a) você está com o seu acesso aos serviços de saúde?

25 Quão satisfeito (a) você está com o seu meio de transporte?

As questões seguintes referem-se à com que freqüiência você sentiu ou experimentou certas coisas nas últimas duas semanas. 
26 - Com que freqüência você tem sentimentos negativos tais como mau humor, desespero, ansiedade, depressão?

$\begin{array}{ccccc}\text { Nunca } & \text { algumas vezes } & \text { freqüentemente } & \text { muito freqüentemente } & \text { sempre } \\ 1 & 2 & 3 & 4 & 5\end{array}$

Você tem algum comentário sobre o questionário? OBRIGADO PELA SUA COLABORAÇÃO 


\section{ANEXO D}

\section{Descrição das Gravuras Apresentadas no Teste de Apercepção para idosos (SAT) (Bellak, 1949/1992)}

Gravura 1 - Três personagens idosos discutindo.

Gravura 3: uma mulher idosa e um homem idoso à esquerda, ambos com as mãos estendidas para o personagem do meio, provavelmente uma criança.

Gravura 4: em primeiro plano, à direita, uma mulher idosa; à esquerda, um personagem indefinido segurando uma criança; uma adolescente no chão, ao telefone, exibindo as coxas com minissaia e o personagem visível em parte, uma mulher de meia-idade na cozinha; ao fundo, uma mesa com cadeiras.

Gravura 5: oito personagens agrupados e isolados em um cenário que pode ser um lar para idosos ou a casa de alguém. Uma grande janela, uma senhora sentada olhando para fora, de costas para a sala, quatro jogadores de cartas em primeiro plano e duas senhoras à direita mexericando; um homem à esquerda lendo jornal.

Gravura 13: uma cena de aeroporto mostrando uma mulher idosa carregando um assar em uma gaiola e um carregador levando bagagem de mão. Há um homem afastado á esquerda.

Gravura 14: Uma cena de banheiro mostrando uma pessoa pegando um vidro de remédio do alto de um armário.

Gravura 15: um homem mais velho dançando com uma mulher mais moça e uma mulher mais velha dançando com um homem mais moço; dois personagens mais velhos afastados no canto.

Gravura 16: a imagem de uma mulher reclinada na poltrona e adormecida. 